UNIVERSIDADE DE SÃO PAULO

FACULDADE DE ECONOMIA, ADMINISTRAÇÃO E CONTABILIDADE

DEPARTAMENTO DE ADMINISTRAÇÃO

PROGRAMA DE PÓS-GRADUAÇÃO EM ADMINISTRAÇÃO

FERNANDA ROSALINA DA SILVA MEIRELES

Stakeholders' Relationships as Microfoundation of Open Innovation: Perspective of Brazilian Companies

Relacionamentos com os Stakeholders como Microfundamentos de Open Innovation: Perspectivas das Empresas Brasileiras 
Prof. Dr. Vahan Agopyan

Reitor da Universidade de São Paulo

Prof. Dr. Fábio Frezatti

Diretor da Faculdade de Economia, Administração, Contabilidade e Atuária

Prof. Dr. Moacir de Miranda Oliveira Junior

Chefe do Departamento de Administração

Prof. Dr. Eduardo Kazuo Kayo

Coordenador do Programa de Pós-Graduação em Administração 


\section{Stakeholders' Relationships as Microfoundation of Open Innovation: Perspective of Brazilian Companies}

\section{Relacionamentos com os Stakeholders como Microfundamentos de Open Innovation: Perspectivas das Empresas Brasileiras}

Tese apresentada ao Departamento de Administração da Faculdade de Economia, Administração e Contabilidade da Universidade de São Paulo, como requisito parcial para obtenção do grau de Doutora em Ciências.

Área de concentração: Administração Geral

Orientador: Prof. Dr. João Maurício Gama Boaventura

\section{Versão Corrigida}

(versão original disponível na Faculdade de Economia, Administração e Contabilidade) 
Catalogação na Publicação (CIP) Ficha Catalográfica com dados inseridos pelo autor

Meireles, Fernanda Rosalina da Silva.

Stakeholders' Relationships as Microfoundation of Open Innovation:

Perspective of Brazilian Companies / Fernanda Rosalina da Silva Meireles. São

Paulo, 2020.

$137 \mathrm{p}$.

Tese (Doutorado) - Universidade de São Paulo, 2020.

Orientador: João Maurício Gama Boaventura.

1. Relacionamentos com os stakeholders. 2. Open innovation. 3.

Reciprocidade. 4. Justiça. 5. Consistência temporal. I. Universidade de São

Paulo. Faculdade de Economia, Administração e Contabilidade. II. Título. 
For Juracy (in memoriam), Livanete, Livia, Odaci e Wallace 



\section{ACKNOWLEDGMENTS}

To the courageous women who, more than family members, have always been an example of love, integrity, determination, empathy, strength, and generosity for me, my mother Livanete and my aunts Juracy (in memoriam) and Odaci. I owe all my education as a human being and all my achievements to you.

To my brother Wallace, for the affection, support, friendship, and companionship of our entire journey together.

To my love Lívia, for all the support, patience, encouragement, clarity, and love. Her tenderness, wisdom, and welcome were and continue to be my lighthouse and guide in the face of life's challenges and choices.

To aunt Francisca, uncle Pedro, and cousins from São Paulo, who made the city of stone warmer.

To professor João Maurício, my advisor, for the support and encouragement. His teachings and example of constant search and overcoming challenges were fuel for my improvement. To professor Mônica Abreu, for all the support and professional model.

To my friends Jordanna and Maiara, who, even though physically distant, always made my life happier, more tender, and pleasant. To the friends that FEA gave me as a gift, Ana Cláudia, Raíssa, and Rafael. The doctorate would not be the same without your affection, teachings, and support. I thank the members of the research group 'Stakeholders \& Networks' for exchanging knowledge and experiences, suggestions, and incentives.

To FEA-USP, for the welcome and excellent instruction provided.

I am grateful for the generosity of everyone who contributed to this exciting and challenging journey. This research was not done alone but had a vast and necessary support network. 

"Sou composta por urgências:

minhas alegrias são intensas;

minhas tristezas, absolutas.

Entupo-me de ausências, esvazio-me de excessos.

Eu não caibo no estreito, eu só vivo nos extremos.

Pouco não me serve, médio não me satisfaz, metades nunca foram meu forte!" 



\section{RESUMO}

Meireles, F. R. S. (2020). Stakeholders' Relationships as Microfoundations of Open Innovation: Brazilian Organizations Perspective (Tese de Doutorado). Faculdade de Economia, Administração, Contabilidade e Atuária, Universidade de São Paulo, São Paulo.

Como o processo de inovação, especificamente a open innovation, envolve a colaboração entre atores intraorganizacionais e extraorganizacionais, compreender as interações e a interface entre estes stakeholders torna-se um objeto de estudo relevante. Ao buscar colaboração e acesso a recursos valiosos, uma organização precisa estabelecer relacionamentos com seus stakeholders, elemento escassamente explorado na perspectiva da open innovation. Ao focar nisso, o presente estudo tem como objetivo geral explicar o relacionamento entre os diferentes relacionamentos com os stakeholders e a open innovation. Com base nos microfundamentos da Teoria dos Stakeholders e na literatura de open innovation, três hipóteses foram propostas. Para testá-las, adotou-se uma abordagem quantitativa, com levantamento de dados secundários do ISE e do INPI, examinando-se 710 observações de empresas brasileiras, com dados de 2008 a 2017. As relações hipotetizadas foram testadas pelo modelo logístico multinomial longitudinal e modelo logístico longitudinal. Em suma, os resultados demonstraram que os relacionamentos com os stakeholders baseados na reciprocidade positiva estão positivamente relacionados à open innovation $\left(\mathrm{H}_{1}\right)$, assim como os relacionamentos com os stakeholders baseados na justiça $\left(\mathrm{H}_{2}\right)$. Além disso, abrangendo as tipologias de justiça, demonstrou-se que os relacionamentos com os stakeholders baseados na justiça distributiva $\left(\mathrm{H}_{2 \mathrm{a}}\right)$ e os relacionamentos com os stakeholders baseados na justiça interacional $\left(\mathrm{H}_{2 \mathrm{~b}}\right)$ também estão positivamente relacionados ao desenvolvimento de open innovation. No entanto, os relacionamentos com os stakeholders baseados na justiça processual $\left(\mathrm{H}_{2 \mathrm{c}}\right)$ não se mostraram relacionados à open innovation. Quanto aos relacionamentos com os stakeholders baseados na consistência temporal $\left(\mathrm{H}_{3}\right)$, os relacionamentos baseados na consistência temporal da reciprocidade $\left(\mathrm{H}_{3 \mathrm{a}}\right)$ demonstraram estar positivamente relacionados a open innovation; por sua vez, os relacionamentos baseados na consistência temporal da justiça $\left(\mathrm{H}_{3 \mathrm{~b}}\right)$ não apresentaram relação com o desenvolvimento da open innovation. A partir destes resultados, evidenciou-se o papel relevante da reciprocidade positiva, da justiça distributiva, da justiça interacional e da consistência temporal da reciprocidade positiva nos relacionamentos com os stakeholders, demonstrando sua relação direta e positiva com o desenvolvimento de open innovation. Dentre as contribuições do estudo destacam-se: (i) identificação dos tipos de relacionamentos com os stakeholders que colaboram para o desenvolvimento de open innovation; (ii) utilização de uma perspectiva sinérgica, que abrange a rede de relacionamentos da open innovation como um todo; (iii) aporte empírico aos microfundamentos da Teoria dos Stakeholders ao provar estatisticamente a relação entre diferentes classificações de relacionamentos com os stakeholders e a open innovation. Em síntese, a principal contribuição deste estudo foi prover um modelo que explique o desenvolvimento de open innovation, ressaltando a importância dos diferentes tipos de relacionamentos desenvolvidos com os stakeholders, atendendo assim à chamada de estudos que avancem na compreensão do papel e motivação dos atores envolvidos neste tipo de inovação e no entendimento da rede de relacionamentos da open innovation como um todo. Além de avançar nos aspectos teóricos, a presente pesquisa fornece uma orientação para os gestores das organizações focados na geração de open innovation, demonstrando para quais atributos e características direcionar esforços e recursos no relacionamento com os stakeholders.

Palavras-chave: Relacionamentos com os stakeholders. Open innovation. Reciprocidade. Justiça. Consistência temporal. 



\begin{abstract}
Meireles, F. R. S. (2020). Stakeholders' Relationships as Microfoundations of Open Innovation: Brazilian Organizations Perspective (Tese de Doutorado). Faculdade de Economia, Administração, Contabilidade e Atuária, Universidade de São Paulo, São Paulo.
\end{abstract}

As the innovation process, specifically open innovation, does not occur in isolation, the interactions and interface between relevant stakeholders is an interesting object of study. While seeking collaboration and access to valuable resources, an organization needs to establish relationships with its stakeholders, an element rarely explored in the perspective of open innovation. By focusing on this, the present study aims to explain the relationship between different stakeholders' relationships and open innovation. Based on the microfoundations of the Stakeholder Theory and the open innovation literature, three hypotheses were proposed. To test these hypotheses, a quantitative approach was adopted, with secondary data collection from ISE and INPI, examining 710 observations of Brazilian companies, with data from 2008 to 2017. The hypothesized relationships were tested by the longitudinal multinomial logistic model and the longitudinal logistic model. Summarily, the results demonstrated that stakeholders' relationships based on positive reciprocity are positively related to open innovation $\left(\mathrm{H}_{1}\right)$, as well as stakeholders' relationships based on justice $\left(\mathrm{H}_{2}\right)$. Besides, covering the typologies of justice, it has been shown that stakeholders' relationships based on distributive justice $\left(\mathrm{H}_{2 \mathrm{a}}\right)$ and stakeholders' relationships based on interactional justice $\left(\mathrm{H}_{2 \mathrm{~b}}\right)$ are also positively related to the development of open innovation. However, stakeholders' relationships based on procedural justice $\left(\mathrm{H}_{2 \mathrm{c}}\right)$ were not related to open innovation. Regarding stakeholders' relationships based on temporal consistency $\left(\mathrm{H}_{3}\right)$, relationships based on temporal consistency of reciprocity $\left(\mathrm{H}_{3 \mathrm{a}}\right)$ proved to be positively related to open innovation; in turn, relationships based on the temporal consistency of justice $\left(\mathrm{H}_{3 \mathrm{~b}}\right)$ were not related to the development of open innovation. From these results, the significant role of positive reciprocity, distributive justice, interactional justice, and temporal consistency of positive reciprocity in the relationships with stakeholders became evident, demonstrating its direct and positive relationship with the development of open innovation. Considering the study's contributions, the following are highlighted: (i) identification of the types of stakeholders' relationships that collaborate for the development of open innovation; (ii) use of a synergistic perspective, which covers the network of open innovation relationships as a whole; (iii) empirical contribution to the Stakeholder Theory microfoundations by statistically proving the relationship between different classifications of stakeholders' relationships and open innovation. In summary, the main contribution of this study was to provide a model that explains the development of open innovation, emphasizing the importance of the different types of relationships developed with stakeholders, thus answering the request for studies that advance in understanding the role and motivation of the actors involved in this type of innovation and in comprehending the relationship network of open innovation as a whole. In addition to advancing the theoretical aspects, this research provides guidance for the managers of organizations focused on the generation of open innovation, demonstrating to which attributes and characteristics to direct efforts and resources in the relationship with stakeholders.

Keywords: Stakeholders' relationships. Open innovation. Reciprocity. Justice. Temporal consistency. 



\section{LIST OF ILLUSTRATIONS}

Illustration 1 - Contrast between the principles of closed innovation and open innovation.....29

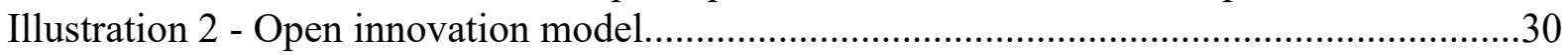

Illustration 3 - Levels of analysis and research objects of open innovation............................33

Illustration 4 - Determinants of open innovation by levels of analysis..................................36

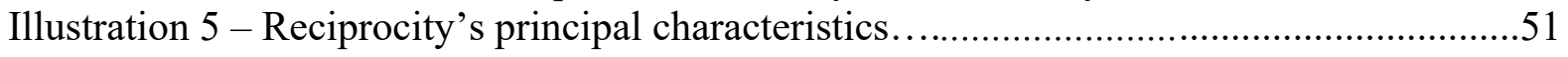

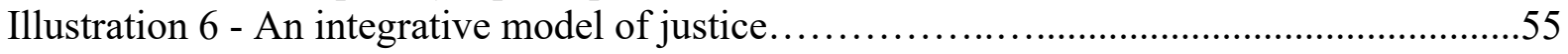

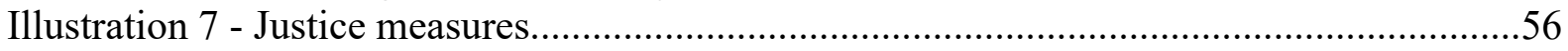

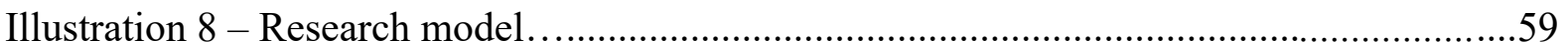

Illustration 9- Questions used for different types of stakeholders'

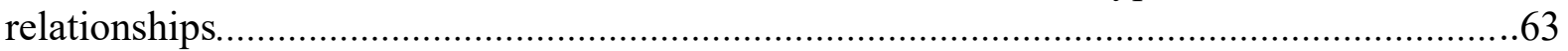

Illustration 10 - Questions used to measure the stakeholders' relationships based on positive

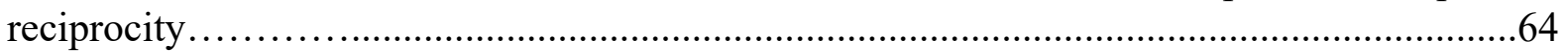

Illustration 11 - Items for measuring the stakeholders' relationships based on justice..........65

Illustration 12 - Summary of the variables used in the research.........................................67

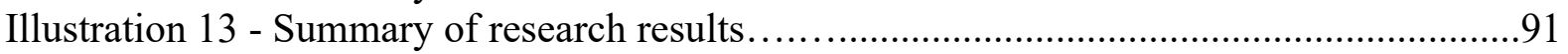





\section{LIST OF TABLES}

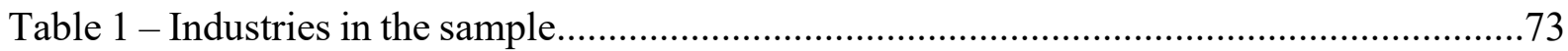

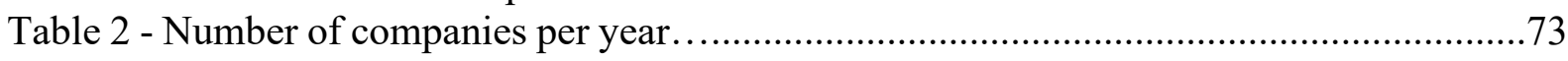

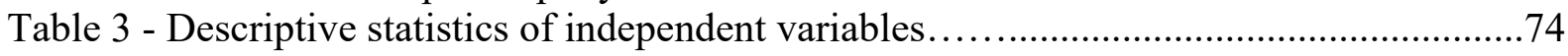

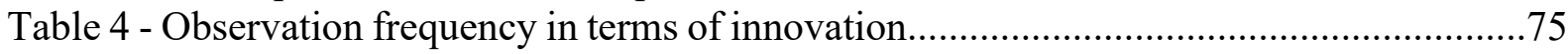

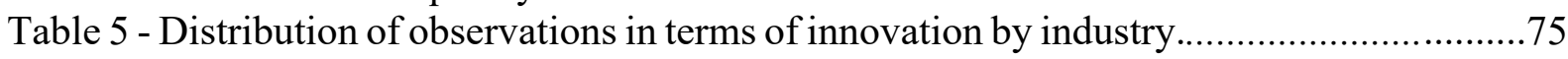

Table 6 - Means of stakeholders' relationships for innovation category.....................76

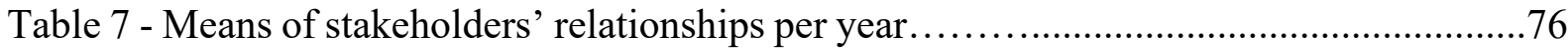

Table 8 - Mean values of stakeholders' relationships by industry....................................77

Table 9 - Estimations of hypothesis 1 in the longitudinal logistic model................................ 79

Table 10 - Measures of intra-class manifest association in random-effects logistic...................80

Table 11 - Measures of intra-class manifest association in random-effects logistic (lag 5 years)

Table 12 - Estimations of hypothesis 2 in the longitudinal logistic model...............................8.

Table 13 - Estimations of hypothesis $2 \mathrm{a}$ in the longitudinal logistic model...............................83

Table 14 - Estimations of hypothesis $2 \mathrm{~b}$ in the longitudinal logistic model..............................84

Table 15 - Estimations of hypothesis $3 \mathrm{a}$ in the longitudinal logistic model..............................85

Table 16 - Estimations of hypothesis 1 in the longitudinal multinomial logistic model............86

Table 17 - Estimations of hypothesis 2 in the longitudinal multinomial logistic model............88

Table 18 - Estimations of hypothesis $2 \mathrm{~b}$ in the longitudinal multinomial logistic model...........89

Table 19 - Estimations of hypothesis $3 \mathrm{a}$ in the longitudinal multinomial logistic model...........90 



\section{TABLE OF CONTENTS}

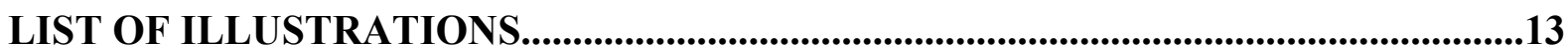

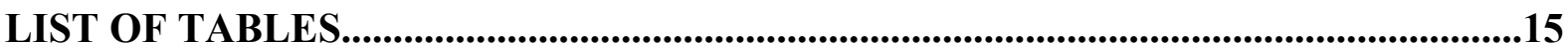

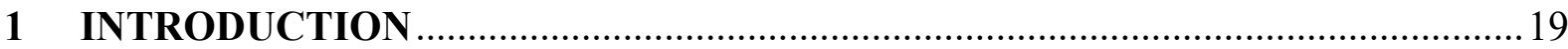

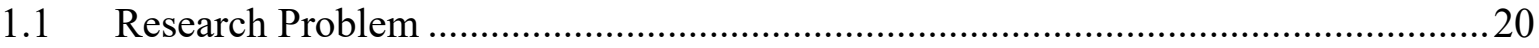

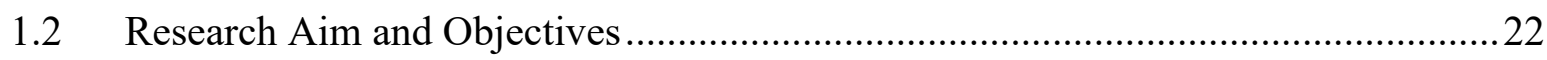

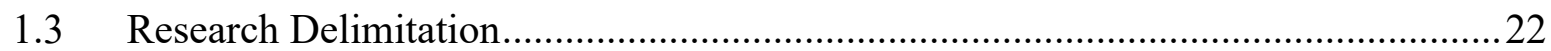

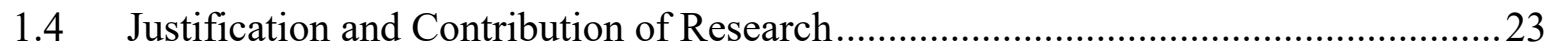

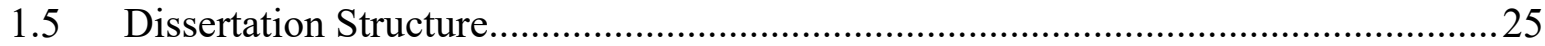

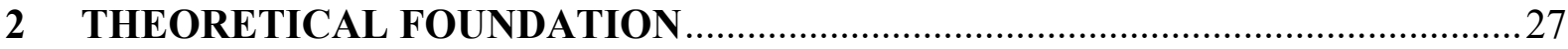

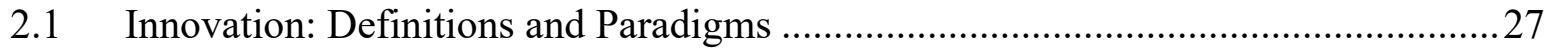

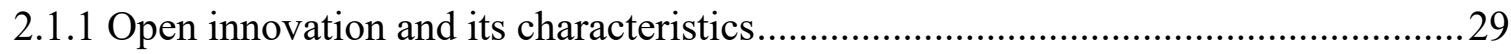

2.1.2 Open innovation as a research object: recognizing its levels of analysis...................32

2.1.3 Determinants of open innovation and its levels of analysis: what does the open

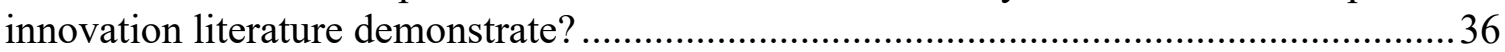

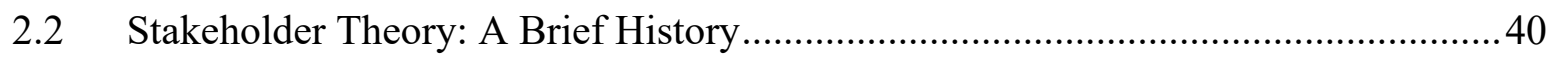

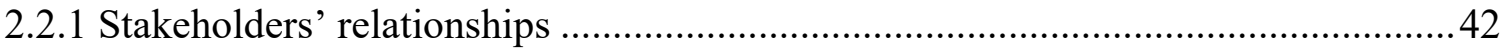

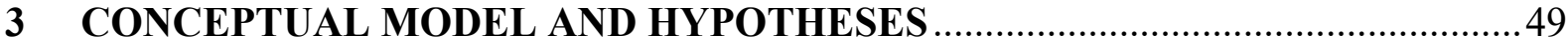

3.1 Stakeholders' Relationships Based on Reciprocity and Open Innovation.....................49

3.2 Stakeholders' Relationships Based on Justice and Open Innovation ............................53

3.3 Stakeholders' Relationships Based on Temporal Consistency and Open Innovation ....57

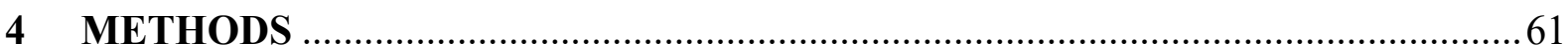

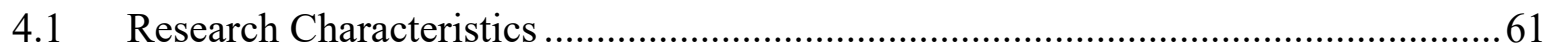

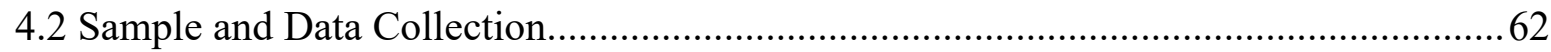

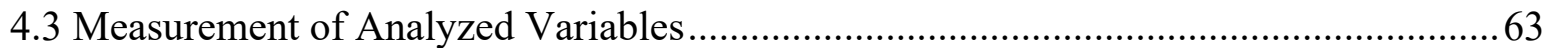

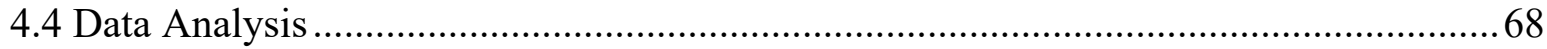

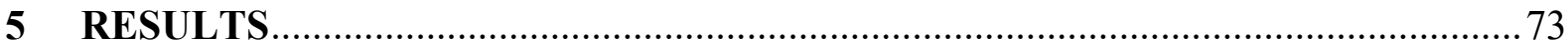

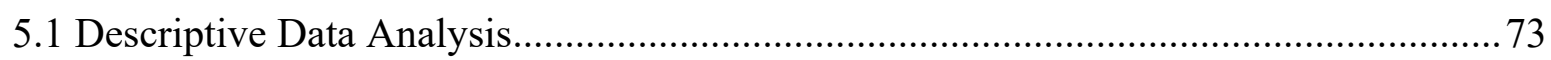

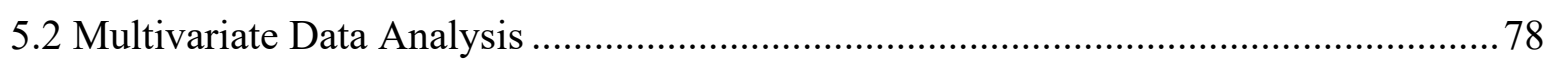

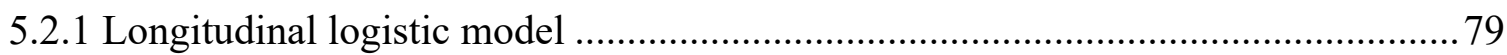

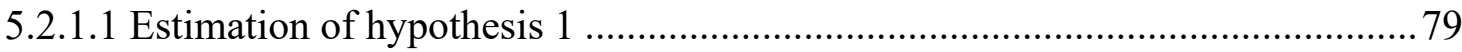

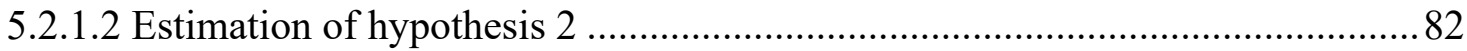

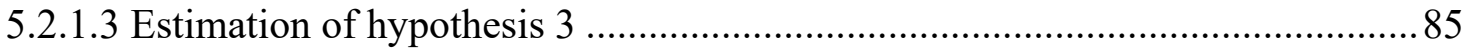

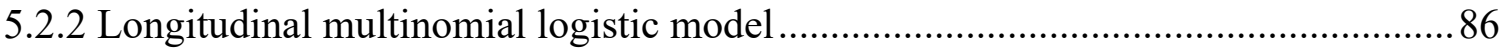

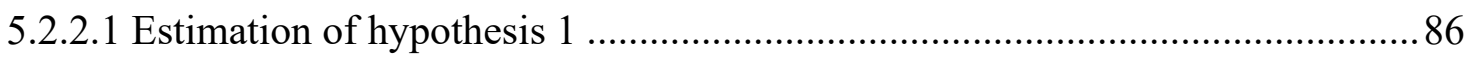

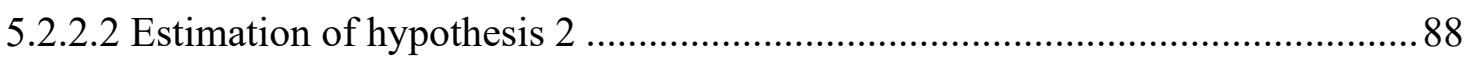




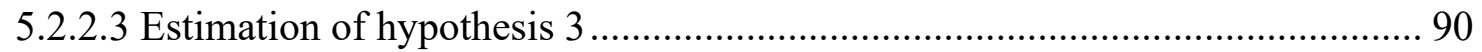

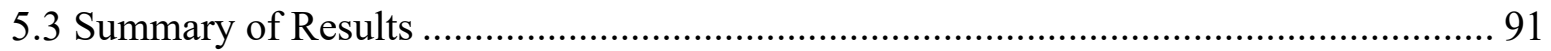

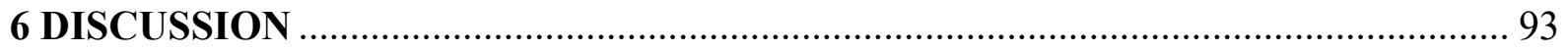

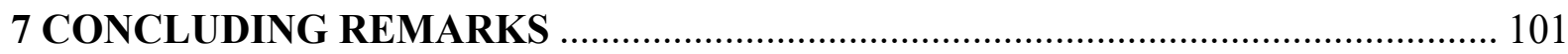

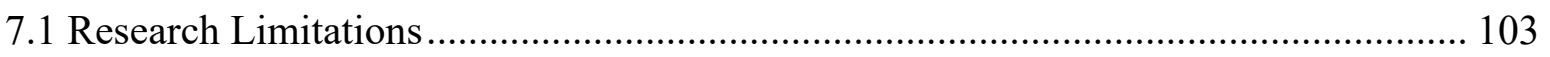

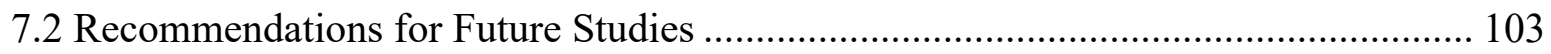

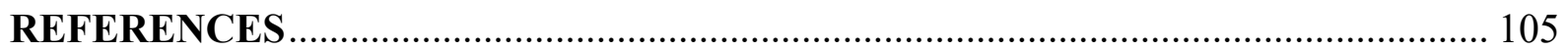

APPENDIX A - ISE QUESTIONS 2017/2018 SELECTED TO MEASURE STAKEHOLDERS' RELATIONSHIPS BASED ON POSITIVE RECIPROCITY.........119 APPENDIX B - ISE QUESTIONS 2017/2018 SELECTED TO MEASURE STAKEHOLDERS' RELATIONSHIPS BASED ON JUSTICE .........................131 


\section{INTRODUCTION}

Innovation is recognized as a source of economic growth (Dew \& Sarasvathy, 2007; Grossman \& Helpman, 1994), improvements in well-being (Baregheh, Rowley \& Sambrook, 2009; Ferreira, Fernandes \& Raposo, 2015), and company survival (Porter, 1990; Schumpeter, 1942). In general, it can be defined as a process by which an idea, object, practice, technology, or process is created, reinvented, developed, disseminated, approved and used; from internal sources and/or acquired from sources outside the organization (Ram, Cui \& Wu, 2010).

The composition of current economic environments, permeated by their high levels of competition, demand from companies' agility and flexibility in innovation processes, leading them to adopt more open and collaborative postures in these processes, causing a phenomenon called open innovation (Chesbrough, 2003). Open innovation is based on collaboration between intra-organizational and inter-organizational actors, creating unique knowledge during this process (Bianchi et al., 2011; Kazadi, Lievens, \& Mahr, 2016).

The centrality and relevance of the diversified forms of collaboration between the organization and individuals in the process and generation of open innovation (Bianchi et al., 2011; Battistella, De Toni, \& Pessot, 2017; Fisher \& Qualls, 2018; Lazzarotti \& Manzini, 2009) require from the organization appropriate mechanisms to align the potential needs and interests of the different actors involved. It is required from the firm the capability to integrate multiple types of tangible and intangible resources (Barney, 2018), creating close relationships that mutually benefits their multiple members over time (Jones, Harrison, \& Phelps, 2018). Furthermore, it is also required the ability to effectively manage their relationships (Gould, 2012; Kazadi, Lievens, \& Mahr, 2016; Simeone, Secundo \& Schiuma, 2017).

Contributing to such mechanisms, the Stakeholder Theory, which considers organizations as the center of a multi-stakeholder network through which different resources are exchanged and combined to achieve particular objectives, provides a framework for analyzing influential actors within and outside the firm (Freeman, 1984; Griffin, 2016; Li, Xia, $\&$ Zajac, 2018). Specifically, the microfoundations of Stakeholder Theory allow us to focus on stakeholders' relationships and the recognition of actors' behaviors and motivations, investigating how their interactions can contribute to performance at the organizational level (Barney \& Felin, 2013; Felin, Foss, \& Ployhart, 2015; Gambeta, Koka, \& Hoskisson, 2019; Garcia-Castro \& Francoeur, 2016).

Building collaborative relationships that are enduring and trustworthy by various stakeholders, whether internal or external, reward the organization with access to critical 
resources such as knowledge, information, and technology (Barney, 2018; Flammer \& Bansal, 2017; Hillman \& Keim, 2001; Salem et al., 2016), allowing the creation and exploration of new ways to co-create value, such as open innovation (Griffin, 2016; Harrison, Bosse, \& Phillips, 2010).

Nevertheless, for the organization to be recognized as trustworthy by stakeholders, establishing and maintaining fruitful relational exchanges with these actors, interactions based on reciprocity are expected (Belmi \& Pfeffer, 2015; Capaldo, 2014; Huang \& Li, 2017), as well as interactions based on justice (Bridoux \& Stoelhorst, 2014; Cropanzano et al., 2001; Wicks, Berman, \& Jones, 1999), and a consistent stance of treating their stakeholders over time (Bosse \& Coughlan, 2016; Brickson, 2007; Jones, Harrison, \& Phelps, 2018; Wang \& Choi, 2013). From this perspective, stakeholder interests should be addressed together, seeking the same direction (Freeman, Wicks, \& Parmar, 2004; Garcia-Castro \& Francoeur, 2016; Tantalo \& Priem, 2016).

\subsection{Research Problem}

The phenomenon of open innovation, defined as "the use of purposeful inflows and outflows of knowledge to accelerate internal innovation, and expand the markets for external use of innovation" (Chesbrough, 2006a, p.1), has attracted the attention of scholars in the field of innovation management (Huizingh, 2011). This interest is illustrated by the increasing number of publications on the subject (Bogers et al., 2017; Cheng \& Huizingh, 2014; Lopes \& Carvalho, 2018).

The wide range of lenses and approaches used in open innovation research has characterized this field as a diverse and fragmented body of knowledge, with multiple and incipient elements and levels of analysis, in addition to little depth in its theoretical foundations (Bogers et al., 2017; Lopes \& Carvalho, 2008; Randhawa, Wilden, \& Hohberger, 2016). There is a concentration of studies at the intra-organizational level of analysis, focusing on the capabilities, competencies, and structure of the focal organization (Caputo et al., 2016; Greco, Grimaldi, \& Cricelli, 2016; Lopes \& Carvalho, 2018). However, there are limited studies that investigate the inter-organizational level, specifically, the network of relationships between the organization and the multiple internal and external actors (Randhawa, Wilden, \& Hohberger, 2016; West \& Bogers, 2014). Little is known about the integration and management of key individuals in the open innovation process (Bogers et al., 2017; Lüttgens et al., 2014). 
In this perspective, research on stakeholders involved in open innovation is suggested, understanding the motives and incentives that stimulate the contribution of these actors to the development of open innovation in an organization (Bogers et al., 2017). In general, the literature presents different studies establishing the link between stakeholders and innovation, especially primary stakeholders (Clarkson, 1995), highlighting the contributions of shareholders (Aghion \& Tirole, 1994; David, Hitt \& Gimeno, 2001; Manso, 2011), employees (Azoulay, Graff, Zivin, \& Manso, 2011), customers (Cui \& Wu, 2016; Desouza et al., 2008), suppliers (Bonaccorsi \& Lipparini, 1994; Sharifi, Ismail \& Reid, 2006; Tavani et al., 2013), and community (West \& Lakhani, 2008).

For the exchanges, sharing, and contributions highlighted by the studies mentioned above actually occur, it is necessary to understand how relationships between stakeholders and the organization develop (Bosse \& Coughlan, 2016; Freeman, 2017). Considering that building collaborative relationships between the organization and its stakeholders allow access to critical resources from varied stakeholders, both internal and external to the organization (Barney, 2018), it demonstrates the importance of stakeholders' relationships for open innovation. However, studies dedicated to explaining how different stakeholders' relationships influence innovation, specifically open innovation, are scarce.

It is also noteworthy that the studies that establish the link between innovation and stakeholders are developed from an individual perspective, considering in isolation the role and influence of each stakeholder on open innovation (Cui \& Wu, 2016; Tavani et al., 2013; West \& Lakhani, 2008). Due to the growing need for sophisticated knowledge for the innovation process, a higher number of qualified and interconnected stakeholders willing to share knowledge and ideas become relevant, suggesting a perspective of multiple stakeholders collaborating simultaneously during the open innovation process (Kazadi, Lievens, \& Mahr, 2016). Therefore, it becomes pertinent to analyze and understand the network of relationships between the various actors as a whole (Randhawa, Wilden, \& Hohberger, 2016).

However, an integrative perspective that considers the influence and contribution of all primary stakeholders on innovation remains scarcely explored, with limited empirical research on this topic (Flammer \& Kacperczyk, 2016), especially considering the panorama of open innovation (Randhawa, Wilden, \& Hohberger, 2016).

Thus, facing the argued problem, involving the relationship between open innovation and stakeholders' relationships, in an integrative perspective, and considering the limitations of the empirical field, the research question proposed in this study is: What is the relationship between different stakeholders' relationships and open innovation? 


\subsection{Research Aim and Objectives}

The aim of this research is to explain the relationship between different stakeholders' relationships and open innovation.

The objectives proposed are:

i. Analyze the relationship between stakeholders' relationships based on positive reciprocity and open innovation;

ii. Analyze the relationship between stakeholders' relationships based on justice and open innovation;

iii. Analyze the relationship between stakeholders' relationships based on temporal consistency and open innovation.

\subsection{Research Delimitation}

The present research is theoretically limited to the instrumental level of the Stakeholder Theory, exploring the relationships between stakeholders' relationships and open innovation (Donaldson \& Preston, 1995; Mainardes, Alves, \& Raposo, 2011). With more in-depth attention to the motivations and behaviors of stakeholders in establishing valuable relationships for open innovation, this research is also based on the microfoundations of the Stakeholder Theory (Hall \& Martin, 2005; Hall, Bachor, \& Matos, 2014; Jones, Harrison, \& Phelps, 2018). In terms of the levels of analysis of open innovation, it establishes a focus on the inter-organizational level, attempting to understand the role of different types of stakeholders' relationships necessary for organizations to develop open innovation (Bogers et al., 2017).

In operational terms, this research is limited to Brazilian companies that answered the ISE (Corporate Sustainability Index) questionnaire, in the years 2008 to 2017. ISE, a pioneering initiative in Latin America, is a tool for comparative analysis of the performance of companies listed on the São Paulo Stock Exchange (B3). The report addresses the aspect of corporate sustainability based on economic efficiency, environmental balance, social justice, and corporate governance, differentiating organizations in terms of the level of commitment, quality, and business performance in the economic-financial, social, environmental, and climate change dimensions (BM\&FBovespa, 2018). 
Aiming at higher reliability and veracity of the data provided by the organizations, the ISE selection process also relies on an analysis of the documents presented by the companies to substantiate the information provided in the questionnaire, experiencing a final deliberation conducted by the ISE Deliberative Council, the CISE. The technical management of this process is conducted by GVces, with the assurance of KPMG (ISE, 2018b). Operationally, questionnaires' answers are used to obtain the score regarding the distribution of value, used as a proxy for stakeholders' relationships in their different types.

In order to identify the presence and classification of innovation in the companies that answered the ISE questionnaire, the database of the National Institute of Industrial Property (INPI) was consulted, the federal agency responsible for services such as: (i) registrations of trademark, industrial designs, geographical indications, computer programs and topographies of integrated circuits; (ii) patent concessions and endorsement of franchise contracts; (iii) transfer of different types of technology (INPI, 2018).

As a proxy for innovation, the presence or absence of patents in that period is used for each of the companies surveyed. For the classification of innovation in closed innovation or open innovation, it was analyzed whether the patent applicants are from different organizations. Patent-based indicators are proxies widely used in research and accepted to measure innovation (Baba, Shichijo \& Sedita, 2009; Guan \& Liu, 2016).

\subsection{Justification and Contribution of Research}

Given the characterization of open innovation as an evolving paradigm, dependent on systemic and interdependent processes, its demand for understanding the mechanisms that contribute to its generation and development is latent, resulting in the broad discussion of the topic by management scholars in the last decade (Chiaroni, Chiesa \& Frattini, 2011; Dodgson, Gann \& Salter, 2006; Felin \& Zenger, 2014).

In light of the relevant points for understanding open innovation, the need to understand the motivations, interactions, and articulation of the relevant actors in its realization is highlighted (Bogers et al., 2017). These individuals, conceptualized as stakeholders, are potential sources of unique knowledge (Kazadi, Lievens, \& Mahr, 2016). Although the emerging discussions in the field of knowledge of open innovation recognize that stakeholders do not innovate in isolation (Laursen \& Salter, 2006), there are limited studies that investigate the integration of these key individuals in the innovation process from the perspective of open innovation (Bogers et al., 2017; Randhawa, Wilden, \& Hohberger, 2016). 
Given the relevance of these multiple actors, their integration can benefit the organization more actively during the innovation process (Gould, 2012; Kazadi, Lievens, \& Mahr, 2016). This integration is better understood through the lens of the Stakeholder Theory, which considers organizations as the center of a network of multiple stakeholders through which different resources are exchanged and combined to achieve specific objectives ( $\mathrm{Li}, \mathrm{Xia}$, \& Zajac, 2018).

In search to create competitive advantages for the organization, including open innovation, it is necessary to establish trustworthy and positive relationships with stakeholders, relationships established and maintained through attending the needs and interests of these actors (Harrison, Bosse, \& Phillips, 2010; Harrison \& Bosse, 2013; Tantalo \& Priem, 2016). Nevertheless, this interface between stakeholders' relationships and open innovation remains a little explored (Meireles, Boaventura, \& Griffin, 2019). It is noticed that the phenomenon of the innovation process in organizations, in its perspective of open innovation, is not adequately elucidated in the literature regarding the influence of stakeholders' relationships, in its different types.

This study defends the thesis that stakeholders' relationships considered reliable, by benefiting from a greater exchange of information and interaction with stakeholders, favor the development of open innovation. Organizations recognized for establishing trustworthy relationships with their stakeholders are rewarded with access and availability of critical information and resources from stakeholders, tools that can be used to create new ways to satisfy stakeholders and generate value, leading to higher levels of innovation (Flammer \& Bansal, 2017; Griffin, 2016; Harrison, Bosse, \& Phillips, 2010; Salem et al., 2016).

From a theoretical point of view, the present research is justified by providing empirical contributions on relevant aspects of Stakeholder Theory, allowing a greater understanding of characteristics and classifications of relevant stakeholders' relationships for better organizational performance (Berman et al., 1999; Harrison, Bosse \& Phillips, 2010; Hillman \& Keim, 2001; Parmar et al., 2010). It contributes to the perspective of the microfoundations of Stakeholder Theory, identifying which attributes present in the relationships with stakeholders motivate these actors to collaborate with the organization, helping the development of open innovation (Barney \& Felin, 2013; Felin, Foss, \& Ployhart, 2015; Gambeta, Koka, \& Hoskisson, 2019; Garcia-Castro \& Francoeur, 2016).

It also contributes to the innovation literature, more specifically to the open innovation literature, by understanding what types of stakeholders' relationships are essential to organizations for the generation of open innovations, deepening the discussions on the inter- 
organizational level and the integration of key stakeholders (Bogers et al., 2017; Lüttgens et al., 2014). Adopting a synergistic perspective (Garcia-Castro \& Francoeur, 2016; Tantalo \& Priem, 2016), considering all the primary stakeholders involved, it contributes to the understanding of the network of relationships between the different actors as a whole (Flammer \& Kacperczyk, 2016; Randhawa, Wilden, \& Hohberger, 2016).

Regarding the practical aspect, this research offers a contribution to the managers of organizations, collaborating so that they can establish efficient and effective strategies and policies to encourage open innovation. Clarifications about stakeholders' relationships will guide managers seeking open innovation, demonstrating which attributes and characteristics to direct efforts and resources in the relationship with stakeholders.

\subsection{Dissertation Structure}

This dissertation is structured in seven chapters. Chapter 1 presents the study introduction, addressing the problem, research question, the aim and objectives, the justification, and the delimitation of the study. Chapter 2 presents the theoretical foundation of this research, addressing the Innovation literature, focusing on the discussion of the characteristics and specificities of open innovation, and Stakeholder Theory, focusing on stakeholders' relationships. Chapter 3 addresses the development of the research hypotheses and the conceptual model.

Chapter 4 presents the methodological procedures adopted to achieve the proposed objectives, describing the characteristics of the research, the sample, and the procedures for collecting, measuring, and analyzing the data. Chapter 5 addresses the research results in statistical terms. For this, the descriptive analyses of the data are demonstrated, followed by the multivariate analyses used to test the hypotheses proposed in Chapter 3.

Chapter 6 presents the discussion of the results, rescuing the research question and the objectives, comparing them with the results presented in Chapter 5. The proposed hypotheses are analyzed and discussed, highlighting the original contributions of the research. Finally, chapter 7 exhibits the conclusion of the research, summarizing the results found, the existing limitations, and recommendations for the development of future studies. 


\section{THEORETICAL FOUNDATION}

The theoretical foundation of this dissertation is anchored in two theoretical frameworks. The first refers to Innovation with a focus on the open innovation approach and its characteristics, demonstrating the importance of multiple sources and interactions in the generation of innovations. The second theoretical field refers to the Stakeholder Theory, focusing on the stakeholders' relationships and the microfoundations of the Stakeholder Theory. It is emphasized that organizations need to manage and build solid relationships with the different groups of stakeholders, contributing to the generation of open innovation.

\subsection{Innovation: Definitions and Paradigms}

Innovation is a multifaceted, multilevel, broad concept studied by researchers under several aspects and through a wide range of research methodologies (Crossan \& Apaydin, 2010; Felin \& Zenger, 2014). In a broad perspective, innovation can be understood as a process, as well as a result. It comprises: (i) the production or adoption, assimilation, and exploitation of an added value novelty in social and economic spheres; (ii) the renovation and/or expansion of products, services, and markets; (iii) the development of new production methods; (iv) and the establishment of new management systems (Crossan \& Apaydin, 2010).

It is configured as the implementation of a new or significantly improved good or service, or a new marketing method, or a process, or a new organizational method in business practices, in the workplace organization, or external relations (OECD, 2005, p.46). Innovation is the process by which existing knowledge and inputs are creatively and efficiently recombined to create new and valuable solutions (Felin \& Zenger, 2014), with the primary function of creating value for the organization and its stakeholders (Lee, Olson, \& Trimi, 2012).

In the last decades, due to the wide dissemination of knowledge (Chesbrough, 2006a), organizations are changing the process they generate ideas and take them to the market, transforming the way knowledge is generated, shifting from a closed innovation paradigm to open innovation (Chesbrough, 2003).

The closed innovation paradigm treats innovation as an internal process for the organization. Meanwhile, the knowledge generated is understood as belonging only to the organization and kept away from other companies and individuals (Berchicci, 2013). It emphasizes the control and execution, within the company, of the entire innovation cycle, since 
the generation of the idea, its development, manufacture, commercialization, services, and distribution (Chesbrough, 2003).

However, due to environmental uncertainties, complexities inherent to innovation, and the recombination of knowledge, this paradigm has become obsolete, resulting in increased permeability of organizational limits and the need for organizations to interact with the environment and external stakeholders in more open ways (Felin \& Zenger, 2014). Directing efforts only to the development of internal capacities and routines has become insufficient to deal with the more significant technological complexity, the increase in costs, and the shortening of the products' life cycle (Berchicci, 2013).

To overcome such obstacles, organizations have become more permeable to the external environment (Cassiman \& Valentini, 2016). In order to respond to the numerous changes in the competitive environment, such as increased turbulence and dynamism, rapid technological development and globalization of markets and business activities, the open innovation paradigm emerged (Bianchi et al., 2011).

The open innovation model considers external and internal ideas as valuable (Chesbrough, 2006a), with the most flexible and porous limits between the organization and the environment that surrounds it (Chesbrough, 2003). Open innovation demands a transformation in the closed limits of the company in a semipermeable membrane, allowing the innovation to move effortlessly between the external environment and the internal innovation process of the company (Chiaroni, Chiesa \& Frattini, 2011).

The organization is no longer seen as the only locus of innovation, having its ideas and knowledge exposed to external partners and integrating with customers, suppliers, and external sources of knowledge to increase its innovation capacity (Berchicci, 2013). This involves extensive use of inter-organizational relations with the various sources of innovation, in order to collect external ideas and commercialize internal ideas, such as universities and research institutions, suppliers, and users (Chiaroni, Chiesa \& Frattini, 2011).

Successfully manage knowledge acquired externally requires the development of complementary internal networks, that is, organizational structures dedicated to access, and integration of knowledge acquired in the company's innovation process (Chiaroni, Chiesa \& Frattini, 2011).

The main differences between the innovation paradigms found in the literature are summarized in Illustration 1, presented by Chesbrough (2003), and yet widely accepted and adopted today. 


\begin{tabular}{|c|c|}
\hline Closed Innovation & Open Innovation \\
\hline $\begin{array}{c}\text { The smart people in our field work with us. } \\
\text { Not all smart people work with us so we must find and tap } \\
\text { into the knowledge and expertise of bright individuals } \\
\text { outside our company. }\end{array}$ \\
\hline $\begin{array}{c}\text { To profit from R\&D, we must discover, } \\
\text { develop and ship it ourselves. }\end{array}$ & $\begin{array}{c}\text { External R\&D can create significant value; internal R\&D is } \\
\text { needed to claim some portion of that value. }\end{array}$ \\
\hline $\begin{array}{c}\text { If we discover it ourselves, we will get it to } \\
\text { market first. }\end{array}$ & $\begin{array}{c}\text { We don't have to originate the research in order to profit } \\
\text { from it. }\end{array}$ \\
\hline $\begin{array}{c}\text { If we are the first to commercialize na } \\
\text { innovation, we will win. }\end{array}$ & $\begin{array}{c}\text { Building a better business model is better than getting to } \\
\text { market first. }\end{array}$ \\
\hline $\begin{array}{c}\text { If we create the most and best ideas in the } \\
\text { industry, we will win. }\end{array}$ & $\begin{array}{c}\text { If we make the best use of internal and external ideas, we } \\
\text { will win. }\end{array}$ \\
\hline $\begin{array}{c}\text { We should control our intellectual property (IP) } \\
\text { so that our competitors don't profit from our } \\
\text { ideas. }\end{array}$ & $\begin{array}{c}\text { We should profit from others' use of our IP, and we should } \\
\text { buy others' IP whenever it advances our own business } \\
\text { model. }\end{array}$ \\
\hline
\end{tabular}

Illustration 1 - Contrast between the principles of closed innovation and open innovation

Source: Chesbrough (2003, p.38).

As it is an emerging paradigm for managing and understanding innovation processes, open innovation is one of the most discussed topics by management scholars in the last decade (Chiaroni, Chiesa \& Frattini, 2011; Felin \& Zenger, 2014). Open innovation is still in gestation, requiring the identification of mechanisms that support the formulation and use of knowledge for an interdependent and systemic innovation process (Dodgson, Gann \& Salter, 2006).

\subsubsection{Open innovation and its characteristics}

Open innovation is a broad concept, which takes many different forms (Dahlander \& Gann, 2010; Huizingh, 2011), and is studied from multiple perspectives (Lichtenthaler, 2011; Cheng \& Huizingh, 2014). It is an umbrella concept that encompasses, connects, and integrates a series of existing activities, increasing its wealth, but hindering to develop the theory. Thus, it becomes necessary to develop open innovation frameworks (Huizingh, 2011).

Defined as "the use of purposeful inflows and outflows of knowledge to accelerate internal innovation and expand the markets for external use of innovation" (Chesbrough, 2006b, p.1), open innovation expands the organization's limits, encouraging greater collaboration, involvement, and variety of participants. The open innovation process combines internal and external ideas in systems, architectures, and platforms (Chesbrough, 2012).

Different definitions and delimitations of the term open innovation include the establishment of relationships with multiple actors (Battistella, De Toni, \& Pessot, 2017; Bianchi et al., 2011; Lazzarotti \& Manzini, 2009), thus emphasizing the centrality and relevance of the various forms of cooperation between organizations and individuals in the process and 
generation of open innovation (Fisher \& Qualls, 2018). Such cooperation occurs in the context of opening organizational boundaries, allowing the exchange of knowledge, resources, and technologies with external stakeholders (Randhawa, Wilden, \& Hohberger, 2016; West \& Gallagher, 2006).

Notably, this paradigm systematically encourages and explores a wide range of internal and external sources in search of innovation opportunities (West \& Gallagher, 2006). For this, internal capacities and external relations are seen as complementary, instead of substitutes (Dahlander \& Gann, 2010).

The underlying assumption of open innovation is the opening of the innovation process (Huizingh, 2011), which is relevant both for internal innovation and for its external exploitation (Martinez-Conesa, Soto-Acosta, \& Carayannis, 2017). Openness, considered a factor that increases the productivity of the innovation process (Cassiman \& Valentini, 2016), is defined by several forms of relationship with external actors and, therefore, is intimately associated with a broader debate about the company's limits (Dahlander \& Gann, 2010).

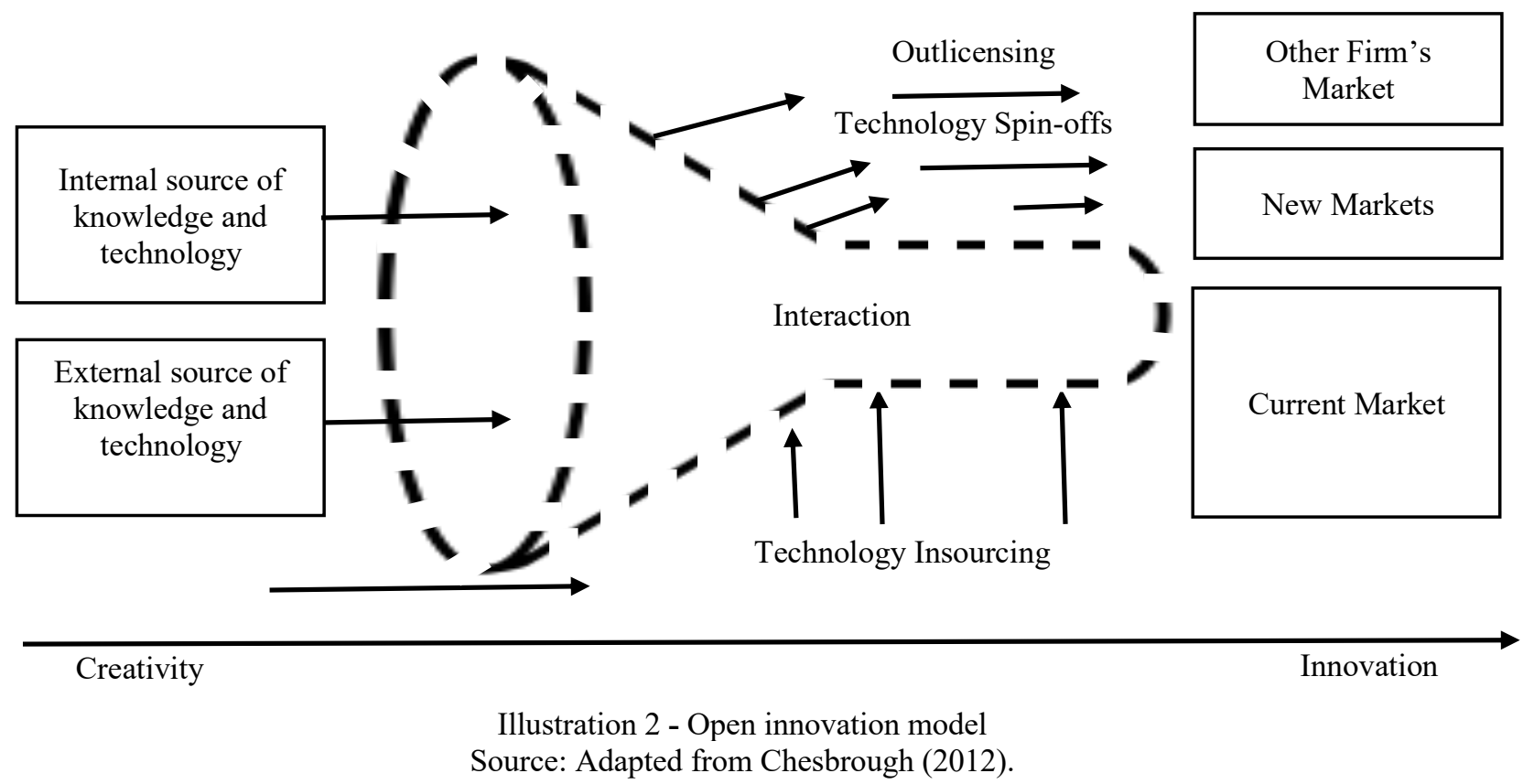

The open innovation system is referred to as open because the boundaries of the product/service development funnel are permeable, allowing some innovation project ideas to be initiated by other parties before entering the internal funnel, as well as other projects leaving the funnel and are developed by other parties (Dittrich \& Duysters, 2007). In the innovation process from the perspective of open innovation, the company's limits are porous 
(Lichtenthaler, 2008). Therefore, projects and ideas can enter or leave at various points and in several ways (Chesbrough, 2012), as shown in Illustration 2.

Open innovation can be understood as composed of three central processes (Cheng \& Huizing, 2014; Enkel, Gassman \& Chesbrough, 2009): outside-in processes (or inbound activities), inside-out processes (or outbound activities), and coupled processes.

Outside-in processes refer to increasing the organization's innovative capacity and knowledge base through the integration of external knowledge sources, such as suppliers, customers, competitors, consultants, research institutes, governments, universities (Cheng \& Huizingh, 2014; Enkel, Gassman, \& Chesbrough, 2009). It is about leveraging the technologies and discoveries of others, needing to open and establish inter-organizational relationships in order to access their technical and scientific skills (Bianchi et al., 2011). Research on inbound activities includes the integration of external partners (Dittrich \& Duysters, 2007; Enkel, 2010; Cheng \& Huizingh, 2014) and new sources of innovative ideas (Fredberg \& Piller, 2011; Cheng \& Huizingh, 2014).

Inside-out processes refer to externalizing knowledge and innovation from internal sources (employees) in order to bring ideas to the market faster than they could through internal development, generating profits for the organization, licensing intellectual property and/or multiplying the technology (Enkel, Gassman, \& Chesbrough, 2009). Therefore, they cover activities involved in the external exploration of internal ideas (Cheng \& Huizingh, 2014; Enkel, Gassman, \& Chesbrough, 2009), establishing, for this purpose, relations with external organizations to which proprietary technologies are transferred for commercial exploitation (Bianchi et al., 2011). Previous studies on internal activities cover multiple types of cooperation, partnerships, alliances, licenses (Un, Cuervo-Cazurra, \& Asakawa, 2010; Cheng $\&$ Huizingh, 2014) and the commercialization of proprietary technologies in new markets (Enkel \& Gassmann, 2010; Cheng \& Huizingh, 2014).

Coupled processes combine outside-in processes with inside-out processes. They refer to collaborative activities between different actors in the innovation system (Enkel, Gassman, \& Chesbrough, 2009; Cheng \& Huizingh, 2014), including co-creation with complementary partners through alliances, cooperation, and joint ventures. In doing so, companies can jointly develop and market innovations (Nieto \& Santamaría, 2007; Cheng \& Huizingh, 2014). Coupled processes have been extensively studied, such as the integration of innovative internal and external information and the coordination of coupled activities between partners (West $\&$ Gallagher, 2006; Cheng \& Huizingh, 2014). Co-creation is widely investigated in open innovation management literature (Enkel, Gassman, \& Chesbrough, 2009). 
Several open innovation activities and processes are significantly and positively related to the four dimensions of innovation performance: (i) innovation of new products/services; (ii) success in the new product/service; (iii) customer performance; (iv) and financial performance (Cheng \& Huizing, 2014). Such influences show that the impacts and effectiveness of open innovation are not limited to particular aspects of innovation performance or product industries, positively influencing a wide variety of innovation performance indicators (Cheng \& Huizingh, 2014; Chesbrough, 2003; Gassman, 2006).

Although it generates several benefits, open innovation has three meaningful challenges: (i) maximization, requiring a wide range of approaches to maximize internal innovation, by diversifying the exploitation of intellectual property resources; (ii) incorporation, involving the identification, incorporation, and absorption of external innovation; (iii) and motivation, focused on encouraging and motivating the generation and sharing of external knowledge (West \& Gallagher, 2006).

While open innovation contributes to positive performance (Almirall \& CasadesusMasanell, 2010; Laursen \& Salter, 2006; Lüttgens et al., 2014), it is emphasized that organizations need to build internal processes and capabilities to take advantage of this opportunity effectively (Bianchi et al., 2011; Dahlander \& Gann, 2010; Lüttgens et al., 2014).

\subsubsection{Open innovation as a research object: recognizing its levels of analysis}

Open innovation is a complex topic that recently attracted considerable attention, both in the practical and academic spheres, receiving contributions from different areas (Gassman, 2006; Huizingh, 2011). Within innovation management, open innovation has spread to different industrial sectors, such as machines, turbines, medical tools, consumer goods, food, architecture, and logistics (Gassman, Enkel, \& Chesbrough, 2010). In terms of the theoretical perspective, since the first works of Chesbrough, a lot has been learned about the content, the context, and the process of open innovation. However, further research is needed (Huizingh, 2011).

Because it is a contemporary research prism, open innovation presents a diverse and fragmented body of knowledge, with multiple levels of analysis, requiring further studies of the elements that constitute it and its theoretical foundations (Bogers et al., 2017; Lopes \& Carvalho, 2008; Randhawa, Wilden, \& Hohberger, 2016). Such fragmentation is demonstrated through the analysis of theoretical essays on the theme, showing the focus of the beforementioned works on the intersection between open innovation and specific business contexts 
and characteristics, such as family business (Feranita, Kotlar, \& De Massis, 2017), start-ups (Spender et al., 2017), metrics used for open innovation (Lamberti et al., 2017), and the perspective of emerging countries (Paulo et al., 2017).

Researches such as those by Randhawa, Wilden, and Hohberger (2016) and Lopes and Carvalho (2018) exhibit a more comprehensive perspective, concerned with understanding the various nuances of open innovation. Fisher and Qualls (2018) focus on the perspective of the interfirm relationship, observing the relationships and exchanges of knowledge between them. In turn, West and Bogers (2014) focus only on external sources of innovation. It can also be observed that the deepening of the discussion on open innovation is recent, dating the relevant literature reviews from 2007 (Perkmann \& Walsh, 2007) and having the year 2017 as a period of great effervescence and focus on review studies on the topic.

Illustration 3 exemplifies the different perspectives and levels of analysis under which open innovation can be investigated. Bogers et al. (2017) delimit the following levels of analysis: intra-organizational level, organizational level, extra-organizational level, interorganizational level, and industry, regional innovation systems, and society level (a level that deals with an institutional environment perspective).

\begin{tabular}{|c|c|c|}
\hline Level of Analysis & Possible Research Object & Exemplary References \\
\hline Intra-organizational & $\begin{array}{l}\text { Individual } \\
\text { Group/Team } \\
\text { Project } \\
\text { Functional area } \\
\text { Business unit }\end{array}$ & $\begin{array}{c}\text { Dahlander, O'Mahony, and Gann } \\
\text { (2016) } \\
\text { Lopez-Vega, Tell, and Vanhaverbeke } \\
\text { (2016) } \\
\text { Antons and Piller (2015) }\end{array}$ \\
\hline Organizational & $\begin{array}{c}\text { Firm } \\
\text { Other (non-firm) organisation } \\
\text { Strategy } \\
\text { Business model }\end{array}$ & $\begin{array}{c}\text { Zobel, Balsmeier, and Chesbrough } \\
\text { (2016) } \\
\text { Foss, Lyngsie, and Zahra (2013) } \\
\text { Chiaroni, Chiesa, and Frattini (2011) }\end{array}$ \\
\hline Extra-organizational & $\begin{array}{l}\text { External stakeholders } \\
\text { Individual } \\
\text { Community } \\
\text { Organisation }\end{array}$ & $\begin{array}{l}\text { Autio, Dahlander, and Frederiksen } \\
\quad \text { (2013) } \\
\text { Bogers, Afuah, and Bastian (2010) }\end{array}$ \\
\hline Inter-organizational & $\begin{array}{l}\text { Alliances } \\
\text { Network } \\
\text { Ecosystem }\end{array}$ & $\begin{array}{c}\text { van der Borgh, Cloodt, and Romme } \\
\text { (2012) } \\
\text { Adner and Kapoor (2010) } \\
\text { Rohrbeck, Hölzle, and Gemünden } \\
\text { (2009) }\end{array}$ \\
\hline $\begin{array}{l}\text { Industry, regional } \\
\text { innovation systems, and } \\
\text { society }\end{array}$ & $\begin{array}{c}\text { Industry development } \\
\text { Inter-industry differences } \\
\text { Local region } \\
\text { Nation } \\
\text { Supra-national institution } \\
\text { Citizens } \\
\text { Public policy } \\
\end{array}$ & $\begin{array}{l}\text { Bogers and Lhuillery (2011) } \\
\text { Chesbrough (2011) }\end{array}$ \\
\hline
\end{tabular}

Illustration 3 - Levels of analysis and research objects of open innovation Source: Adapted from Bogers et al. (2017, p.12). 
Intra-organizational level of analysis is concerned with understanding the challenges faced by individuals in charge of implementing open innovation strategies, as well as understanding open innovation at the functional and project level. Research suggestions at the intra-organizational level include: a more detailed understanding of the reasons that motivate some individuals to embrace open innovation; understanding of how managers select and subsequently manage multiple open innovation opportunities and initiatives; examine how projects, middle management or strategic initiatives at an intermediate organizational level support open innovation activities at the company level; understanding of the structure needed by companies to adapt and incorporate innovative suggestions from internal and external sources to the company; investigate more specifically the impact of the division of innovative work, in terms of units and different organizational structures, on the success rate of development, identification, and integration of external knowledge; among others (Antons \& Piller, 2015; Bogers et al., 2017; Dahlander, O’Mahony, \& Gann, 2016; Lopez-Vega, Tell, \& Vanhaverbeke, 2016).

Organizational level of analysis is dedicated to organizational designs, practices, and processes to integrate external sources of innovation, as well as open innovation in the context of new entrants, small and medium-sized companies, and entrepreneurs. Research suggestions for this level include: an examination of organizational-level problems that overlap or connect to open innovation and entrepreneurship, as well as the contingencies that predict success in such environments; more in-depth understanding of how diverse open innovation approaches conduct to different types of business opportunities, processes and results; understanding of the of open innovation effectiveness from a business model perspective; better understanding of the relationship between open innovation and crowdsourcing (Bogers et al., 2017; Chiaroni, Chiesa, \& Frattini, 2011; Foss, Lyngsie, \& Zahra, 2013; Zobel, Balsmeier, \& Chesbrough, 2016).

Extra-organizational level of analysis attempts to understand the role of external stakeholders (users or communities) in the innovation process from the perspective of open innovation. It covers the following research suggestions: understanding the contributions of external stakeholders, as well as the stages of the innovation process in which they are involved; understanding how heterogeneity and cognitive distance between internal and external contributors influence the dynamics of knowledge creation and the production of innovation; comprehend the effectiveness of open innovation in the varied contexts of relationships between diverse types of extra-organizational individuals and different types of knowledge creation and 
innovation processes (Autio, Dahlander, \& Frederiksen, 2013; Bogers, Afuah, \& Bastian, 2010; Bogers et al., 2017).

The inter-organizational level of analysis sheds light on how organizations practice open innovation in ecosystems and industrial platforms. Through the theoretical lens of networks, open innovation depicts new dynamic network structures that emerge from the dynamic interactions of a diverse set of actors throughout the innovation process. Research suggestions at this level cover: the relationship between the effectiveness of open innovation and the issue of governance in these dynamic relationships; understanding of how "open" that governance should be; understanding of the extent and conditions under which open innovation can be complemented with intellectual property protection to help stimulate vibrant innovation ecosystems; understanding of specific challenges related to innovation management in platform-based ecosystems, taking into account competition within the ecosystem itself and platform-based ecosystems (Adner \& Kapoor, 2010; Bogers et al., 2017; Rohrbeck, Hölzle, \& Gemünden, 2009; van der Borgh, Cloodt, \& Romme, 2012).

In turn, industrial, regional and societal level of analysis is concerned with the applications of open innovation outside the areas of $\mathrm{R} \& \mathrm{D}$, such as manufacturing, marketing, strategy, services, tourism, and education. It considers as relevant to open innovation the contingencies at the sectoral level, from different societies and regions. It presents as research suggestions: a better understanding of the multidimensional complexities of specific conditions of industries and companies concerning open innovation; comprehension of how to integrate spaces for open innovation in larger innovation ecosystems; better understanding of the application of open innovation at the level of cities, regions, and nations; application of open innovation in the public sector (Bogers et al., 2017; Bogers \& Lhuillery, 2011; Chesbrough, 2011).

Bogers et al. (2017) suggest that the limits between different levels of analysis are becoming more permeable, and future research should adopt a cross-level approach. A recommended research category is 'open innovation stakeholders', focused on the actors of open innovation, their individual or organizational attributes, and the reasons and incentives that drive their contribution to the open innovation initiative of an organization (Bogers et al., 2017).

It is also noteworthy that, among the multiple perspectives studied, researches that investigate the strategic orientation of companies (Cheng \& Huizingh, 2014; Bogers et al., 2017) and the integration of relevant key individuals in overcoming barriers are limited (Lüttgens et al., 2014; Bogers et al., 2017). Given the importance of the active involvement of 
external stakeholders (individuals or communities) in the innovation process, recognized as essential contributors to the creation and exchange of knowledge, and as critical elements related to open innovation effectiveness (Bogers et al., 2017), research in the meantime becomes essential.

It is necessary to place more emphasis on the reasons and incentives for individuals to contribute to open innovation activities at the company level. Thus, the interface between stakeholders becomes a crucial object of study (Bogers et al., 2017).

\subsubsection{Determinants of open innovation and its levels of analysis: what does the open innovation literature demonstrate?}

In order to increase knowledge of open innovation, a systematic literature review was carried out, thus consolidating the research developed on open innovation in a context of cooperation. For that, the methodology of Crossan and Apaydin (2010) was adopted. The ISI Web of Knowledge's Social Sciences Citation Index (SSCI) database was chosen as the search base for the papers. Specifically, three groups of keywords were searched: 'open innovation' and 'collaborat*'; 'open innovation' and 'cooperat*'; 'open innovation' and 'partner*'. The search was performed using the filters document type 'article' and 'review'; language 'English' and 'Portuguese'; and area 'business'. The keywords were used as selection criteria in the topic field (title, keywords or abstract), resulting in an initial sample of 366 papers. After filtering, analysis of abstracts and deleting repeated papers, it was obtained a final sample of 35 articles, with papers published in a period of five years, from 2013 to 2017.

\begin{tabular}{|c|c|}
\hline \multicolumn{2}{|c|}{ Intra-organizational Level } \\
\hline $\begin{array}{l}\text { Structural aspects: } \\
\text { Size; multinationality; growth stage; nature of the } \\
\text { organization's ownership; internationalization; export } \\
\text { intensity; equity; legal capacity of the company. }\end{array}$ & $\begin{array}{l}\text { Cano-Kollman, Hamilton III, and Mudambi } \\
\text { (2017); Caputo et al. (2016); Chen, } \\
\text { Vanhaverbeke, and Du (2016); Cheng and } \\
\text { Huizingh (2014); Greco, Grimaldi, and Cricelli } \\
\text { (2016); Janeiro, Proença, and Gonçalves (2013); } \\
\text { Love, Roper, and Vahter (2014); Spithoven, } \\
\text { Vanhaverbeke, and Roijakkers (2013); Veer, } \\
\text { Lorenz, and Blind (2016); Wang, Cheng, and } \\
\text { Shen (2015) }\end{array}$ \\
\hline Functional/operational aspects: & \\
\hline $\begin{array}{l}\text { Employees qualification; organizational support } \\
\text { competence; technological aptitude competence; strength of } \\
\text { the internal resource bases; degree of modularity of the } \\
\text { resource base; existing organizational capabilities in } \\
\text { extracting value from external knowledge. }\end{array}$ & $\begin{array}{l}\text { Alexy, George, and Salter (2013); Appleyard, } \\
\text { and Chesbrough (2017); Chen, Vanhaverbeke, } \\
\text { and Du (2016); Love, Roper, and Vahter (2014) }\end{array}$ \\
\hline
\end{tabular}




\begin{abstract}
Strategic aspects:
Company strategy; business model objectives; factors oriented to the company; strategic orientation; focus on the company's stakeholders; organization's values.
\end{abstract}

Knowledge and innovation aspects:

Internal innovation activities; spending on innovation; introduction of market innovation; level of success of the company's innovation; level of innovation intensity; R\&D capabilities; R\&D expenses; previous experience of innovation ties; subsequent patent citation; technological record; coupled OI; the company's ability to establish and benefit from relationships with multiple partners; costs of searching for relevant agents.
Alexy, George, and Salter (2013); Almirall, Lee, and Majahrzak (2014); Appleyard and Chesbrough (2017); Cheng and Huizingh (2014)

Cano-Kollman, Hamilton III, and Mudambi (2017); Caputo et al. (2016); Chen, Vanhaverbeke, and Du (2016); Chesbrough (2017); Greco, Grimaldi, and Cricelli (2016); Iturrioz, Aragón, and Narvaiza (2015); Janeiro, Proença, and Gonçalves (2013); Love, Roper, and Vahter (2014); Spithoven, Vanhaverbeke, and Roijakkers (2013); Veer, Lorenz, and Blind

(2016); Wang, Cheng, and Shen (2015)

\begin{tabular}{|c|c|}
\hline \multicolumn{2}{|c|}{ Inter-organizational Level } \\
\hline $\begin{array}{l}\text { Purpose and results of the network: } \\
\text { Scope of R\&D cooperation - different phases in which } \\
\text { companies cooperate; Research and development } \\
\text { cooperation - different types of collaboration partners; } \\
\text { Simultaneous collaborative development of standards; } \\
\text { Aspects of socialization in the transfer of knowledge in } \\
\text { collaboration with partners; Reputation as a successful and } \\
\text { fair partner; Satisfaction/dissatisfaction with the result. }\end{array}$ & $\begin{array}{l}\text { Dingler and Enkel (2016); Gebauer, Füller, and } \\
\text { Pezzei (2013); Veer, Lorenz, and Blind (2016) }\end{array}$ \\
\hline $\begin{array}{l}\text { Types of members: } \\
\text { Type of partner (value chain partner, science-based partner, } \\
\text { technological partner, horizontal connection). }\end{array}$ & $\begin{array}{c}\text { Chen, Vanhaverbeke, and Du (2016); Love, } \\
\text { Roper, and Vahter (2014) }\end{array}$ \\
\hline $\begin{array}{l}\text { Network organization: } \\
\text { Type of technological collaboration - horizontal or vertical; } \\
\text { Levels/stages of the partnership; Types of collaborations - } \\
\text { formal vs. informal; focused on the market vs. focused on } \\
\text { science; Governance mechanisms; Presence of } \\
\text { intermediaries; Capabilities of intermediaries. }\end{array}$ & $\begin{array}{c}\text { Alexander and Martin (2013); Alexy, George, } \\
\text { and Salter (2013); Gesing et al. (2015); Iturrioz, } \\
\text { Aragón, and Narvaiza (2015); Veer, Lorenz, } \\
\text { and Blind (2016); Wang, Cheng, and Shen } \\
\text { (2015) }\end{array}$ \\
\hline $\begin{array}{l}\text { Bonds nature: } \\
\text { Share capital; Commitment; Confidence; Reciprocity; } \\
\text { Safety of the environment; History of previous and current } \\
\text { relationships and cooperation with other agents. }\end{array}$ & Iturrioz, Aragón, and Narvaiza (2015) \\
\hline $\begin{array}{l}\text { Network configuration: } \\
\text { Network configuration; Structural compatibility level; } \\
\text { External search breadth; External search depth. }\end{array}$ & $\begin{array}{c}\text { Alexy, George, and Salter (2013); Greco, } \\
\text { Grimaldi, and Cricelli (2016); Iturrioz, Aragón, } \\
\text { and Narvaiza (2015) }\end{array}$ \\
\hline $\begin{array}{l}\text { Flows nature: } \\
\text { Content compatibility level; Technological trajectory } \\
\text { phase; Shared beliefs of the agents involved; Proximity } \\
\text { between the objectives and agendas of the different } \\
\text { stakeholders. }\end{array}$ & $\begin{array}{c}\text { Alexy, George, and Salter (2013); Iturrioz, } \\
\text { Aragón, and Narvaiza (2015) }\end{array}$ \\
\hline
\end{tabular}




\begin{tabular}{|c|c|}
\hline \multicolumn{2}{|c|}{ Extra-organizational Level } \\
\hline $\begin{array}{l}\text { Govern: } \\
\text { Has the company benefited from public financial support } \\
\text { from local, regional and central governments; Government } \\
\text { support for R\&D; Monetary support from the government; } \\
\text { Non-monetary government support; Relevance of public } \\
\text { support. }\end{array}$ & $\begin{array}{l}\text { Cano-Kollman, Hamilton III, and Mudambi } \\
\text { (2017); Greco, Grimaldi, and Cricelli (2016); } \\
\text { Love, Roper, and Vahter (2014) }\end{array}$ \\
\hline $\begin{array}{l}\text { Environment: } \\
\text { Industry; Technological turbulence; Competitive } \\
\text { environment; Market-oriented factors; Ecosystem; Region; } \\
\text { Home countries; Country R\&D intensity; Country IP } \\
\text { protection; GDP per capita. }\end{array}$ & $\begin{array}{l}\text { Alexy, George, and Salter (2013); Almirall, } \\
\text { Lee, and Majchrzak (2014); Appleyard and } \\
\text { Chesbrough (2017); Cano-Kollman, Hamilton } \\
\text { III, and Mudambi (2017); Cheng and Huizingh } \\
\text { (2014); Chen, Vanhaverbeke, and Du (2016); } \\
\text { Gesing et al. (2015); Greco, Grimaldi, and } \\
\text { Cricelle (2016); Spithoven, Vanhaverbeke, and } \\
\text { Roijakkers (2013); Veer, Lorenz, and Blind } \\
\text { (2016); Wang, Cheng, and Shen (2015) }\end{array}$ \\
\hline $\begin{array}{l}\text { Community: } \\
\text { Perception of fairness, and sense of community. }\end{array}$ & Gebauer, Füller, and Pezzei (2013) \\
\hline $\begin{array}{l}\text { Consumers: } \\
\text { Consumer pressure for new configurations or greater } \\
\text { variety; Co-creation experience. }\end{array}$ & $\begin{array}{c}\text { Appleyard and Chesbrough (2017); Gebauer, } \\
\text { Füller, and Pezzei (2013) }\end{array}$ \\
\hline $\begin{array}{l}\text { Engagement: } \\
\text { Motivation/demotivation of external collaborators. }\end{array}$ & $\begin{array}{c}\text { Alexy, George, and Salter (2013); Almirall, } \\
\text { Lee, and Majahrzak (2014) }\end{array}$ \\
\hline
\end{tabular}

Illustration 4 - Determinants of open innovation by levels of analysis. Source: Author (2020).

The bibliometric analysis of the selected papers shows a high focus on organizational (business) factors, connected to the characteristics of the focal organization. It is possible to observe that most of the determinants investigated in this literature cover the characteristics, capacities, and skills of the company (about $42 \%$ of the total determinants). Because of the relevance of the organization, it was used as a reference for the classification of determinants at extra-organizational, intra-organizational, and inter-organizational levels (Bogers et al., 2017). Such divisions are shown in Illustration 4, where each level, its subdivisions, and respective papers are presented.

Despite the predominance of determinants at the intra-organizational level, the analyzed period reveals an increasing attention at the characteristics of the relationship or the relationship network for open innovation (Alexy, George, \& Salter, 2013; Gesing et al., 2015; Iturrioz, Aragón, \& Narvaiza, 2015; Veer, Lorenz, \& Blind, 2016; Wang, Cheng, \& Shen, 2015), focus on the inter-organizational level, relevant and fundamental locus for the categorization of innovations in open innovation. 
Through analyzing the annual distribution of papers, it is noted that there are studies that address both the intra-organizational level and the extra-organizational level during the entire period investigated (2013 to 2017). It was noted that the determinants of intraorganizational level have always been approached from multiple perspectives over the years, with papers addressing at least two categories at the intra-organizational level. By investigating the phenomenon of open innovation, the category of determinants 'knowledge and innovation aspects', as well as the category 'structural aspects', was omnipresent in the period of analysis, demonstrating a congruence between the phenomenon investigated and its intra-organizational determinants.

The other levels, both the extra-organizational level and the inter-organizational level, receive less attention from the researches analyzed. The 'environment' category exhibits greater prominence, appearing in all years. Therefore, the relevance of the characteristics of the environmental and institutional context in which open innovation is developed is emphasized. In terms of stakeholders, the consumer group, investigated in two of the five years, is highlighted.

The inter-organizational level focused on the relationship/network of connections between the stakeholders involved in open innovation, also exhibits a large number of categories, subdivided according to the work of Cova, Prévot, and Spencer (2010). This level is the least present level in the analyzed period, with no research in 2017. In terms of the determinants of the inter-organizational level, the categories 'network organization' and 'network configuration' are highlighted, focusing on the types of cooperation and the external actors, as well as in the governance mechanisms of such networks.

The review enabled the recognition of the absence of a prevalent and consistent theoretical basis. It is shown papers focusing on different features, classifications, and determinants of open innovation according to the underlying theory applied (RBV, theories related to learning and knowledge management). For example, the actors involved in the open innovation process, depending on the underlying theoretical lens, are given the name of partners, stakeholders, or participants/members of a specific group (Alexander \& Martin, 2013; Alexy, George, \& Salter, 2013; Gebauer, Füller, \& Pezzei, 2013; Gesing et al., 2015).

In addition to the information on conducting open innovation, the studies require further clarification and deepening as to the characteristics and configurations of the open innovation analyzed, better typifying its stages and the outcomes generated. Such information would allow a better categorization and understanding of the antecedents, requirements, types, and duration 
of the cooperation, actors involved, and other details to generate the different outcomes of this type of innovation, highlighting the motivating particularities of each of the results.

The findings of the systematic review illustrate the primary focus of research at the organizational level. Despite the relevance of the capabilities and structure of the focal organization, the decisive point for classifying innovation as open innovation is the complex network of relationships between the company and other actors and/or organizations (Chesbrough, 2006a; Dittrich \& Duysters, 2007). However, the perspective that covers this central point, the inter-organizational level, is poorly developed in the literature. Little is known about the nature, organization, governance, configuration, actors involved, and results of this network.

Several participants internal and external to the organization, such as customers, community, suppliers, employees, universities, are invited to the innovation process as partners and co-producers (Chesbrough, 2012). In order to develop the ideas and knowledge coming from the various partners, an organization must have a structure, architecture, and systems that allow for interaction, resulting in several spin-offs and innovations. From this perspective, Stakeholder Theory, with its focus on multilateral relationship building between the organization and its stakeholders (Beaulieu \& Pasquero, 2002; Griffin, 2016; Parmar et al., 2010), can provide important contributions to the open innovation model

\subsection{Stakeholder Theory: A Brief History}

Stakeholder Theory emerged in the 1980's and is based on Freeman's book (1984), Strategic Management: a stakeholder approach. Stakeholders are then defined as any individual or group that may affect or be affected by the company in the achievement of organizational objectives (Freeman, 1984, p.46). As highlighted by Donaldson and Preston (1995), since the publication of Freeman's book (1984), the idea that companies have stakeholders has become commonplace in management literature. Lately, there has been a popularization and indiscriminate use of the term 'stakeholder', often utilizing it to exemplify something far from the concept brought by the theory (Mainardes, Alves, \& Raposo, 2011).

This theory has its origins in four academic fields (sociology, economics, politics, and ethics), besides to the literature on corporate planning, systems theory, corporate social responsibility, and organizational theory (Mainardes, Alves, \& Raposo, 2011). Stakeholder Theory is distinguished by addressing morals and values explicitly as a central feature of 
management organizations; it is, therefore, a theory of organizational management and ethics (Phillips, Freeman, \& Wicks, 2003).

A central principle of Stakeholder Theory is the concept of organizations as a set of relationships between groups or individuals that have some interest in the organization's processes and activities (Donaldson \& Preston, 1995; Freeman, 1984; Freeman et al., 2010). In this perspective, the organization is at the center of a network of stakeholders, performing the role of a complex system for exchanging resources, goods, services, information, technology, among others (Freeman, 1984; Rowley, 1997; Harrison, Bosse, \& Phillips, 2010; Li, Xia, \& Zajac, 2018). Thus, Stakeholder Theory suggests that we adopt as a unit of analysis the relationships between a company and its stakeholders (Parmar et al., 2010). Therefore, there is a focus beyond the organization, covering relationships with stakeholders located outside its spectrum.

As highlighted by Freeman, Wicks, and Parmar (2004), the Stakeholder Theory focuses on two questions: what is the purpose of the organization, what is management's responsibility to stakeholders. These questions encourage managers to articulate the shared sense of the value they create, as well as to reflect on what types of relationships they want and need to create with their stakeholders to fulfill the organization's purpose.

In its evolution, significant contributions were brought in the 1990s, especially by the works of Clarkson (1995), Donaldson and Preston (1995), Mitchell, Agle, and Wood (1997) and Rowley (1997). Clarkson's research (1995) classifies stakeholders as primary or secondary, stating that the primary stakeholders should receive more attention from the organization due to its high degree of interdependence with it. Within this category are customers, shareholders, employees, suppliers, and the community.

Donaldson and Preston (1995) contribute to the Stakeholder Theory by proposing that it be analyzed under three dimensions: the descriptive dimension (describes and/or explains organizational characteristics and behaviors related to stakeholders), the instrumental dimension (includes the cause and effect) and the normative dimension (covers the premises of the Stakeholder Theory, this dimension being its central core).

In turn, Mitchell, Agle, and Wood (1997) contribute by establishing the model of stakeholder salience that identifies and prioritizes stakeholders according to the attributes of power (which branches into coercive power, utilitarian power, and normative power), urgency and legitimacy. In this model, the higher the number of attributes the stakeholder presents, the more prominent the stakeholder will be considered by the manager, and the more attention he should receive from the organization. 
Rowley (1997) examined the influence of stakeholders on the organization from a network perspective, analyzing the density of the stakeholder network and the centrality of the formal organization. When considering the perspective of relationship networks and no longer dyadic relationships, Rowley (1997) provides a mechanism to describe the simultaneous influence of various stakeholders on the organization. It is stated that, according to the stakeholder central position in the network, he has more or less power.

Despite the progress achieved by the Stakeholder Theory, Phillips, Freeman, and Wicks (2003) highlight that it furthermore has some limits, points to be investigated and better defined: the issue of managerial opportunism (the manager serves several groups, with the risk of opportunistic behavior); the Theory's imprecision regarding the question of the objective function of organizations; the definition of how to allocate resources to stakeholders; the issue of equal treatment of stakeholders.

The most recent models of Stakeholder Theory have focused on the issue of creating and distributing value to stakeholders, also highlighting the role of managing for stakeholders, with allocation of resources to satisfy the needs and interests of legitimate stakeholders, in creation of competitive advantages for the organization (Garcia-Castro \& Aguilera, 2015; Garcia-Castro \& Francoeur, 2016; Harrison, Bosse, \& Phillips, 2010; Harrison \& Bosse, 2013; Tantalo \& Priem, 2016).

\subsubsection{Stakeholders' relationships}

The literature highlights the critical role played by stakeholders in the business environment, demonstrating the consequent need to analyze, involve, and manage them in order to guarantee benefits to the organization (Beaulieu \& Pasquero, 2002; Susnienè \& Vanagas, 2007). Stakeholders, dynamic players, are relevant constituent parts of the management process (Beaulieu \& Pasquero, 2002).

When conceptualizing an organization from the Stakeholder Theory perspective, conceiving it as a set of value creation relationships between groups and/or individuals that have some interest in the processes and activities of the organization (Belmi \& Pfeffer, 2015; Donaldson \& Preston, 1995; Freeman et al., 2010; Freeman, 2017), it is essential to consider the multilateral construction of relationships between the organization and its stakeholders (Beaulieu \& Pasquero, 2002). This concept of organization implies that favorable relationships and links with stakeholders, internal and external, are important assets of the company and part 
of its current wealth as well as part of its ability to generate more wealth in the future (Barney, 2018; Jones, Harrison, \& Phelps, 2018; Susnienė \& Vanagas, 2006).

This definition introduces as a critical point in understanding the relationships between shareholders, communities, customers, suppliers, employees, and managers for value creation (Freemam, 2017), where the instrumental perspective of Stakeholder Theory suggests adopting the relationships between the organization and its stakeholders as an appropriate unit of analysis (Donaldson \& Preston, 1995; Griffin, 2016; Parmar et al., 2010; Rowley, 1997), especially when the organization is searching for a sustainable competitive advantage (Barney, 2018; Jones, Harrison, \& Phelps, 2018).

The relevance and centrality of the relationship construct highlight the importance of understanding it more deeply by identifying and explaining its specificities, evolution, causes, dimensions, and effects. It is urgent to understand the nature, typology, and content of stakeholder relationships (Bosse \& Coughlan, 2016; Freeman et al., 2010; Freeman, 2017), by providing new ways of thinking about companies and their multiple and sometimes conflicting relationships with stakeholders (Griffin, 2016).

The relationship construct is understood as the interactions between two parties that encourage each party involved to experience emotions, establish some form of a psychological bond, and motivate each party involved to take action on behalf of the other (Bosse \& Coughlan, 2016). These interactions, from the perspective of Stakeholder Theory, can be studied at different levels of abstraction: i) low level of abstraction - the relationship can be understood as a connection or interaction between two individuals (Jones, Harrison, \& Phelps, 2018; Sluss \& Ashforth, 2008); ii) intermediate level of abstraction - the relationship can be understood as a connection or interaction between the organization and a specific group of stakeholders (Bosse \& Coughlan, 2016; Jones, Harrison, \& Phelps, 2018); iii) high level of abstraction - the relationship can be understood as a connection or interaction between the organization and all stakeholders simultaneously (Jones, Harrison, \& Phelps, 2018).

Focusing on stakeholder relationships creates an entirely different structure for the decisions considered by management, which is not only focused on the company, but also on creating value for today's stakeholders, without compromising long-term stakeholder value (Hörisch, Freeman, \& Schaltegger, 2014). That change in the perspective and approach of stakeholder management generates an explicit focus on the individualities and specificities of the stakeholders, who are no longer seen as mere occupants of generic roles, but as individuals with emotions, perceptions, motivations, and different behaviors (Bosse \& Coughlan, 2016; McVea, \& Freeman, 2005). 
The organization, therefore, begins to develop value creation strategies with better results by integrating moral and ethical responsibilities into the business, focusing on personal relationships with its stakeholders (McVea \& Freeman, 2005). It is noteworthy further the necessity of adopting a dynamic and changing view of relationships with stakeholders, considering the effect of stakeholder management approaches of the company (Bridoux \& Stoelhorst, 2014; Griffin, 2016).

Repeated interactions help build trust and empathy, resulting in deeper stakeholder relationships (Flammer \& Bansal, 2017; Jones, 1995; Tantalo \& Priem, 2016; Wang \& Choi, 2013), relationships rewarded through the acquisition of intangible resources such as legitimacy, reputation, increased stakeholder commitment to the organization, greater value creation potential, and competitive advantage (Flammer \& Bansal, 2017; Luo \& Bhattacharya, 2006; Tantalo \& Priem, 2016). Meanwhile, long-term horizons help strengthen and establish relationships with stakeholders of the organization (Flammer \& Bansal, 2017), contributing to the company's survival as well as to a sustainable competitive advantage (Barney, 2018; Flammer \& Bansal, 2017; Hillman \& Keim, 2001; Salem et al., 2016).

Another critical factor in generating and maintaining stakeholders' relationships is the articulation of mutual benefits since individuals and organizations tend to maintain relationships when this serves their interests (Griffin, 2016; Mitchell, Agle, \& Wood, 1997; Susniené \& Vanagas, 2007). The mutual benefits to those involved allow the creation of successful relationships, based on a common agreement that generates interdependence among stakeholders (Susniené \& Vanagas, 2007). However, when there are no mutual benefits between the company and its stakeholders, the relationship loses the attention of value creation generators and tends to be disrupted (Bosse \& Coughlan, 2016; Griffin, 2016).

Process of generating benefits for stakeholders includes knowledge and attending their interests, integrating them with the organization's concerns (Freeman, 1984; Donaldson \& Preston, 1995; Salem et al., 2016). Since before-mentioned stakeholders integration occurs, the firm acquires the ability to establish a reliable and positive cooperative relationship with a wide range of stakeholders (Freeman, Wicks \& Parmar, 2004; Salem et al., 2016; Susniené \& Vanagas, 2007). Thus, organizations, when treating their stakeholders well, are recognized as trustworthy and conscientious, obtaining as a result an efficient attraction and retention of stakeholders (Freeman, Harrison, \& Wicks, 2007; Harrison \& Bosse, 2013) and consequent competitive advantage and success (Harrison \& Bosse, 2013; Stankevičienė \& Vaiciukevičiūtė, 2016). 
Although the organization spends resources on building these relationships, its expenses are compensated by gains from the knowledge of the stakeholders' utility functions, which can lead to competitive advantage and higher levels of innovation (Harrison, Bosse \& Phillips, 2010). The utility function refers to the preference of stakeholders for different combinations of tangible and intangible results, both economic and non-economic, arising from the actions taken by the firm. It is worth mentioning that stakeholders continually update their preferences and utility functions (Bosse \& Coughlan, 2016; Harrison, Bosse, \& Phillips, 2010; Tantalo \& Priem, 2016; Priem et al., 2019). Stakeholders reveal information about their utility functions to organizations considered to be reliable, that fairly distribute the value created, and give a voice to stakeholders in decision making. Therefore, in this process, justice and reciprocity are central concepts (Bosse, Phillips, \& Harrison, 2009; Bosse \& Phillips, 2016; Harrison, Bosse, \& Phillips, 2010).

In order for the organization to have greater competitive advantages, it must have a consistent posture in terms of its stakeholder approach, with consistent treatment of its stakeholders over time (Bosse \& Coughlan, 2016; Brickson, 2007; Bridoux \& Stoelhorst, 2014; Colquitt \& Rodell, 2011; Harrison, Bosse, \& Phillips, 2010; Harrison \& Bosse, 2013; Jones, Harrison, \& Phelps, 2018). This behavior enables the company to become known for being fair and to acquire stakeholder management skills, making this kind of management part of the culture of the organization over time (Harrison, Bosse, \& Phillips, 2010), considering that the organization's ability to manage stakeholders' relationships can be a determinant of business success (Salem et al., 2016).

Building positive and cooperative relationships between the company and its stakeholders, which is the basis for gaining competitive advantage, allows access to critical resources of diverse actors, both within and outside the organizational boundaries (Barney, 2018), thus highlighting the importance of such relationships for open innovation. The strengthening and deepening of stakeholders' relationships enable the creation and exploration of new ways to co-create value (Griffin, 2016). Thus, multiple interactions with various types of stakeholders, if leveraged, can be valuable sources of knowledge for the organization's innovation process, especially open innovation (Kazadi, Lievens, \& Mahr, 2016).

In line with studies of Stakeholder Theory that emphasize the importance of cooperative relationships (Bridoux \& Stoelhorst, 2014; Freeman, 1984; Freeman et al., 2010; Phillips, 2003), a more detailed look at the microfoundations of the Theory, highlighting stakeholder behaviors and motivations, suggests that for the construction of these relationships, reciprocity, justice, and temporal consistency are demonstrated as extremely important factors. 


\subsection{Looking at Microfoundations: Stakeholders' Relationships and Open Innovation}

The specificities and characteristics of open innovation emphasize the importance of the exchange of information and knowledge with the organization (Bogers et al., 2017; Chesbrough, 2006a; Randhawa, Wilden, \& Hohberger, 2016). Briefly, open innovation processes require interaction and disclosure, leading to the sharing of confidential information with and among stakeholders, whether or not this is the intention of the (focal) innovation organization. The actors involved in the open innovation process can have significant interactions with other participants outside the control of the (focal) innovation organization, which increases the likelihood of unintentional leakage within and beyond the open innovation process (Gould, 2012).

Based on more realistic assumptions about the behaviors and motivations of individuals, the microfoundations of Stakeholder Theory illustrate and emphasize stakeholders' relationships and the consequent demand for a more careful and conscious understanding of the relational capacity of the organization (Hall \& Martin, 2005; Hall, Bachor, \& Matos, 2014; Jones, Harrison, \& Phelps, 2018). The greater detail and focus on firms as collections of relationships between stakeholders, that is, as collections of individuals, highlights that information and knowledge are not owned by the organization but by the individuals within it (Barney \& Felin, 2013). Therefore, it is emphasized that organizational relationships can be impacted by individuals, with uncertainties compounded over time (Bridoux \& Stoelhorst, 2014).

Microfoundations emphasize the need to comprehend the interactions between individuals (stakeholders), which assume complex forms, with unique, surprising, and challenging to predict additive effects, surprising and challenging to predict, in addition to considering the context of the organization (Barney \& Felin, 2013; Gambeta, Koka, \& Hoskisson, 2019; Garcia-Castro \& Francoeur, 2016). This detailed and focused look on stakeholders as individuals allows to unpack collective concepts and thus understand how factors at the individual level affect organizations, how the interactions and relationships of individuals lead to emerging results and performance, collective and organizational level (Felin, Foss, \& Ployhart, 2015).

In order to avoid the leakage of information, open innovation needs appropriate mechanisms to align the potential needs and interests (claims) of the different actors involved (Simeone, Secundo, \& Schiuma, 2017). The instrumental literature on Stakeholder Theory emphasizes that, by attending the interests and demands of relevant stakeholders and creating 
a relationship of mutual trust with multiple stakeholders simultaneously, over time, the organization can benefit from more significant innovation and value creation (Harrison, Bosse, \& Phillips, 2010; Jones, Harrison, \& Phelps, 2018). In short, intangible assets such as legitimacy, reputation, and trust help to prepare (build/generate) a virtuous circle of innovation and co-creation of wealth (Flammer \& Kacperczyk, 2016; Luo \& Bhattacharya, 2006; Sen \& Bhattacharya, 2001; Surroca, Tribó, \& Waddock, 2010).

By examining relationships as microfoundations for open innovation, it is possible to illustrate the importance of stakeholder interactions and the integration of resources between organizations, including organizations with multiple or opposite reasons (Bridoux \& Stoelhorst, 2014). Consequently, without close and sustained relationships with stakeholders (Jones, Harrison, \& Phelps, 2018), no interaction and integration of resources occur, and open innovation is obstructed. 


\section{CONCEPTUAL MODEL AND HYPOTHESES}

This section argues that the development of innovations, from the perspective of open innovation, is influenced by the type of stakeholders' relationships practiced by the organization. This argument is developed based on three mechanisms: 1) companies develop relationships with their stakeholders; 2) stakeholders' relationships seen as reliable and positive allow for a greater exchange of information, and more significant interaction of stakeholders with the organization; 3) a higher number of interactions, as well as a more considerable amount of shared knowledge quality information, favor the development of open innovations. In this research, the types of stakeholders' relationships are operationally represented by the different value distribution practices used by the organization.

\subsection{Stakeholders' Relationships Based on Reciprocity and Open Innovation}

Relationship building based on mutual cooperation and trust is a key factor in meeting stakeholders' needs, enabling the consequent management of these groups (Bosse, Phillips, \& Harrison, 2009; Harrison, Bosse, \& Phillips, 2010; Jones, 1995). These relationships, especially mutual cooperation relationships, are essential to organizations for the development of open innovation (Feller et al., 2009), as they stimulate creative problem solving (Susniene \& Vanagas, 2006), benefiting both the organization and its stakeholders with the development of innovations. Being a complex social process that involves social interaction between the various members inside and outside the company, the success of open innovation depends on effective building relationships, communication, and cooperation between people and groups from different backgrounds (Huang \& Li, 2017; Mooi \& Frambach, 2012).

In this context, cooperation is reinforced by the norm of reciprocity, considering that relying on reciprocity allows people to balance the resources they have with the resources they need and also to balance the exchange of resources over time (Belmi \& Pfeffer, 2015; Goldstein, Griskevicius, \& Cialdini, 2011). Reciprocity helps to build, develop, and maintain productive relational exchanges, thereby influencing cooperative behavior in interactions between partners (Chen \& Hung 2010; Huang \& Li, 2017; Pervan, Bove, \& Johnson, 2009).

Reciprocity is a cornerstone of cooperative exchange relationships (Hoppner \& Griffith, 2011) and, thanks to its potential to reward and penalize the behavior of the parties involved, the exchange partners are motivated to continue cooperating in the long run (Axelrod, 2006; 
Hoppner \& Griffith, 2011; Tsaur \& Wang, 2011). Therefore, it is observed that cooperation, an essential item for open innovation, can take the form of reciprocity (Levine \& Prietula, 2014).

Reciprocity involves the principle of mutual benefit (Rawls, 1971, p.88) and means that in response to friendly actions, people are generally much more pleasant and cooperative, a behavior known as positive reciprocity. On the other hand, in response to hostile actions, individuals are often very unpleasant, a behavior that is known as negative reciprocity (Fehr \& Gächter, 2000). This contingent mutual benefit exchange between participants in a relationship is responsible for establishing the order and stability of the relationship (Fehr \& Falk, 2002; Huang \& Li, 2017; Lin, Hung, \& Chen, 2009; Tsaur \& Wang, 2011).

Recognized as a characteristic that drives the relationship between the organization and its legitimate stakeholders (Martinez, 2019), reciprocity is characterized by a more widespread exchange where returns are not necessarily immediate or similar but where over time, an exchange dynamic is achieved (Homans, 1958; Pervan, Bove, \& Johnson, 2009). The positive results achieved through the consistent exchange of goods and the productive response to problems, reflected by reciprocity, should lead to higher levels of satisfaction with the relationship (Pervan, Bove, \& Johnson, 2009).

Therefore, the reciprocity rule refers to a set of socially accepted rules concerning a transaction, establishing that a party, when extending a resource to another, obliges the latter to return the favor (Gouldner, 1960; Pervan, Bove, \& Johnson, 2009). This is a situation "in which a person is expected to cooperate with individuals who have done something for that person first" (Goldstein, Griskevicius, \& Cialdini, 2007, p.147), thus reflecting the individuals' involvement in mutual recognition and in the reaction to the other person's action, which adds interactional and bilateral dimensions (Liu et al., 2018; Martinez, 2019).

Reciprocity's core is the perception of the impartiality of transactions, observed through the process in which the total value is generated and divided between the parties in the relationship (Hu \& Korneliussen, 1997; Tsaur \& Wang, 2011). Reciprocity emphasizes the attitudes of the cooperating parties towards the mutual exchange of resources, fair distribution of benefits, mutual understanding, and trust (Chen \& Hung, 2010; Wasko \& Faraj, 2005).

Critical characteristics of reciprocity are highlighted in Illustration 5. As noted, this term is a multifaceted and complex concept (Hoppner \& Griffith, 2011; Liu et al., 2018; Pervan, Bove, \& Johsnon, 2009; Swärd, 2016).

The various characteristics of reciprocity point to the need for a first move, perceived as friendly, legitimate, and desirable by stakeholders, given that reciprocity is a friendly or unfriendly response to the behavior received (Hahn, 2015). In this process of exchanging 
positive behaviors, reciprocity emerges through two components: the first is goodwill reciprocity; the second is the equivalence of contributions (Liu et al., 2018).

\begin{tabular}{|c|c|}
\hline Characteristics & Source \\
\hline Balance in the exchange of resources over time & Goldstein, Griskevicius, and Cialdini (2011) \\
\hline Mutual benefit & Oliver (1991); Rawls (1971) \\
\hline Bilateral & Liu et al. (2018) \\
\hline Search for common interests and goals & Oliver (1991) \\
\hline $\begin{array}{l}\text { "Glue that connects parts where friendships or other social } \\
\text { dimensions are not evident" }\end{array}$ & Pervan, Bove, and Johnson (2009, p. 67) \\
\hline $\begin{array}{l}\text { It plays a major role in the governance of inter-organizational } \\
\text { relations }\end{array}$ & Muthusamy and White (2005) \\
\hline $\begin{array}{l}\text { Interactional dimension (involvement of individuals in } \\
\text { mutual recognition and reaction to the other person's action) }\end{array}$ & Martinez (2019) \\
\hline $\begin{array}{l}\text { Establishing two interrelated demands: (1) people must help } \\
\text { those who helped them, and (2) people must not harm those } \\
\text { who helped them }\end{array}$ & Gouldner (1960) \\
\hline Expectation of future behavior & Pervan, Bove, and Johnson (2009) \\
\hline Key source of resources and learning & $\begin{array}{c}\text { Chen and Hung (2010); Huang and Li } \\
\text { (2017); Lin, Hung, and Chen (2009); Wasko } \\
\text { and Faraj (2005) }\end{array}$ \\
\hline It demonstrates functionality in building cooperation & $\begin{array}{c}\text { Goldstein, Griskevicius, and Cialdini (2011); } \\
\text { Gouldner (1960) }\end{array}$ \\
\hline $\begin{array}{l}\text { Fundamental to social stability and relational exchange } \\
\text { supporter }\end{array}$ & Gouldner (1960); Homans (1958) \\
\hline Obligation to return favor & Cialdini (2001); Gouldner (1960) \\
\hline Perception of the fairness of transactions & $\mathrm{Hu}$ and Korneliussen (1997) \\
\hline Powerful exchange rule & $\begin{array}{l}\text { Capaldo (2014); Cropanzano and Mitchell } \\
\text { (2005); Emerson (1976) }\end{array}$ \\
\hline $\begin{array}{l}\text { A continuous process of satisfaction of expectations; } \\
\text { psychological contract }\end{array}$ & Levinson (1965) \\
\hline
\end{tabular}

Illustration 5 - Reciprocity's principal characteristics

Source: Author (2020).

Thus, in order to obtain relationships that have a positive reciprocity component, this research considers goodwill reciprocity as the company's first reciprocity movement concerning its stakeholders. Goodwill reciprocity refers to the mutually contingent exchange of gratifications and actions that can be interpreted by the stakeholders as signs of goodwill (Liu et al., 2018; Swärd, 2016), as elements that can be represented by the tangible and intangible resources provided by the organization (Harrison, Bosse, \& Phillips, 2010; Harrison \& Bosse, 2013; Tantalo \& Priem, 2016).

As benefits of reciprocity, its role as a critical element in inter-organizational exchanges is observed (Capaldo, 2014; Dwyer, Schurr, \& Oh, 1987; Liu et al., 2018; Zhang et al., 2016), as well as its role as a significant and robust driver for the formation of new ties of knowledge, acting in the stabilization of relationships over time and making interactions more fluid and spontaneous (Giuliani, 2013). Since the efforts invested in knowledge sharing, by following the norm of reciprocity, can be reciprocated, members are motivated to contribute more (Chang \& 
Chuang, 2011; Chen \& Hung, 2010; Huang \& Li, 2017). Thus, a positive reciprocity effort is observed (Fehr \& Gächter, 2000).

The action by the partner can be reciprocated in different ways, such as through showing solidarity (Dwyer, Schurr, \& Oh, 1987; Hoppner \& Griffith, 2011; Swärd, 2016), flexibility (Hoppner \& Griffith, 2011; Lusch \& Brown, 1996; Swärd, 2016), or exchanging information (Hoppner \& Griffith, 2011; Jap \& Anderson, 2007; Liu et al., 2018; Swärd, 2016). Reciprocity provides extra motivation, in addition to economic incentives, to develop and maintain relationships (Huang \& Li, 2017; Pervan, Bove, \& Johnson, 2009).

Organizations are more willing to share their knowledge when they expect to receive other knowledge, or future help in return (Huang \& Li, 2017; Wasko \& Faraj, 2005; Wincent et al., 2010), and so frequent learning or regular interaction is more likely to happen when there is a reciprocal relationship (Huang \& $\mathrm{Li}, 2017$ ). Reciprocity underpins repeated and recurrent participation in knowledge transfer and co-production processes, as well as in internal knowledge development processes (Capaldo, 2014). However, when reciprocal actions are absent, exchange partners have little motivation to engage in behaviors that benefit the relationship (Falk \& Fischbacher, 2006; Hoppner \& Griffith, 2011).

These benefits, arising from positive reciprocity, mainly the exchange of knowledge and information among stakeholders, are relevant drivers of open innovation. As demonstrated by Chesbrough (2004), the existence of diverse sources of information, technologies, and knowledge, whether internal or external, is relevant to the development and generation of open innovations. By accessing more sources, the organization increases its likelihood of gaining valuable insights into the innovation process (Leiponen \& Helfat, 2010), enabling the organization to achieve its objectives (Barney 2018).

An organization that has relationships with its stakeholders based on positive reciprocity benefits from cooperation, knowledge, and information exchange (Hoppner \& Griffith, 2011; Liu et al., 2018; Swärd, 2016), which are key drivers of open innovation (Bogers et al., 2017; Chesbrough, 2012), thus resulting in a higher probability of open innovation being generated. It is suggested that stakeholders' relationships based on positive reciprocity influence open innovation. Therefore, the first hypothesis is proposed:

Hypothesis 1: Stakeholders' relationships based on positive reciprocity are positively related to the development of open innovation. 


\subsection{Stakeholders' Relationships Based on Justice and Open Innovation}

Justice is perceived in Stakeholder Theory as a fundamental component, directly affecting the relationship between the organization and its stakeholders (Bosse, Phillips \& Harrison, 2009; Freeman, 1984; Harrison, Bosse, \& Phillips, 2010; Hayibor, 2017; Phillips, Freeman, \& Wicks, 2003). Viewed as a mechanism for bringing people together (Aguilera et al., 2007; Cropanzano et al., 2001), justice is used as a guide for the behavior of individuals, who are particularly sensitive to their perception of fair and unfair treatment (Bosse, Phillips, \& Harrison, 2009; Lind, 2001; Melé, 2014).

Both the perceived treatment of stakeholders of the focal organization and the treatment received by that company are essential in the evaluation of justice (Phillips, 1997). Therefore, considerations of justice are central in the understanding of company-stakeholder relationships (Hayibor, 2017). According to Cropanzano and Ambrose (2015), the word justice refers to ethical appropriateness and moral correctness, reflecting situations in which people have been treated and/or received what they deserve. In terms of Stakeholder Theory, justice can be understood as a fundamental equality among stakeholders in terms of their moral rights (Freeman, 1994).

Several theoretical frameworks explored an explanation for how the perception and/or evaluation of justice is formed, highlighting equity theory (Adams, 1965), cognition/fairness theory (Folger, 1986), and fairness heuristic theory (Lind, 2001). Among these, fairness heuristic theory demonstrates a more complete and relevant view of this cognitive process (Cropanzano et al., 2001). In general, what individuals mean by justice is not based on a single transaction, but a fair relationship. Therefore, the perception of fairness of treatment is better thought of in relational terms (Lind, 2001).

Justice, from the perspective of the individual-organization relationship, can be described as focusing on the antecedents and consequences of three types of subjective perceptions: (i) distributive justice, (ii) procedural justice, and (iii) interactional justice (Bosse, Phillips \& Harrison, 2009; Colquitt, 2001; Cropanzano et al., 2001). In terms of distributive justice, actors establish their perceptions of justice based on the distribution and/or allocation of material outcomes, the ultimate result of the system (Bosse, Phillips, \& Harrison, 2009; Colquitt et al., 2001; Goodstein \& Butterfield, 2010; Harrison \& Wicks, 2013). In this case, the individual determines if they are being treated fairly by analyzing the ratio between their inputs (effort, time, cognitive resources) and the outcomes they have received (pay, promotion, 
opportunities for professional development), and then they compare this ratio with the inputoutput ratio of another individual (Adams, 1965; Cropanzano et al., 2001).

Interactional justice concerns the treatment of actors in regular interactions, including respectful, polite, and civilized behavior, truthfulness of communication, and appropriate sensitivity and concern towards affected parties (Bosse, Phillips, \& Harrison, 2009; Colquitt et al., 2001; Goodstein \& Butterfield, 2010; Harrison \& Wicks, 2013). Interactional justice can be understood through four criteria (Bies, 2015; Colquitt \& Ambrose, 2015): (i) justification, which refers a thorough explanation of procedures; (ii) truthfulness, which refers to an honest explanation of procedures; (iii) respect, which refers to the polite and sincere enactment of procedures; and (iv) propriety, which refers to refraining from improper remarks in the enactment of procedures.

Finally, procedural justice corresponds to the definition of rules and procedures that guide the resource allocation process, as well as the procedures used to achieve the results (Bosse, Phillips, \& Harrison, 2009; Colquitt et al., 2001; Harrison \& Wicks, 2013; Leventhal, 1980). According to Leventhal (1980), there are six criteria that the processes should satisfy in order to be perceived as fair: (i) they must be consistent among individuals and over time; (ii) they must be free from bias, avoiding personal self-interest and blind allegiance to narrow preconceptions; (iii) they must be based on precise information, with minimum of error, highlighting their accuracy; (iv) they must have some mechanism to modify or reverse wrong decisions; (v) they must reflect and represent the primary concerns and values of individuals affected by the process; and (vi) they must be based on moral and ethical values.

In this sense, studies of organizational justice identify three classes of events that are evaluated in terms of justice: results - distributive justice; processes - procedural justice; and interpersonal interactions - interactional justice (Cropanzano et al., 2001). Stakeholders use their perceptions of justice in these events to choose the levels of resources they make available and the effort they devote to the organization. If the individual considers the interaction, distribution, and/or process to be fair, they will be inclined to apply more effort (Bosse, Phillips, \& Harrison, 2009).

Considering the three constructs that form justice, Cropanzano et al. (2001) propose an integrative perspective, which can be better understood through Illustration 6 . 


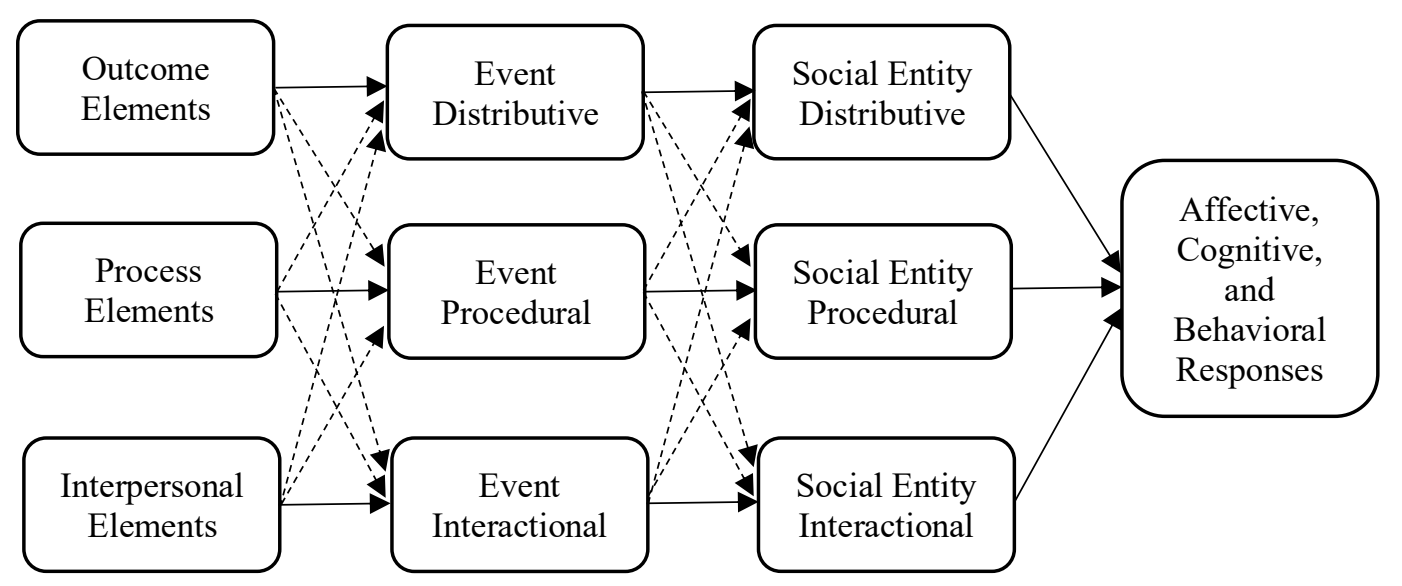

Illustration 6 - An integrative model of justice Source: Cropanzano et al. (2001).

The model exhibited in Illustration 6 exemplifies the two critical steps for the perception of justice, illustrated by the horizontal arrows. In the first phase, three events occur: (i) outcome elements cause perceptions of distributive justice; (ii) process elements cause perceptions of procedural justice; and (iii) interpersonal elements cause perceptions of interactional justice. In the second phase, the perceptions of justice are aggregated, helping the individual to form a judgment about a social entity (Cropanzano et al., 2001).

This integrative view shows a mutual influence between the three types of justice, something supported by the theory given the substitutability effect. The predominant type of justice, which has the most significant influence on others, depends on the incident or element observed at the time of the justice experience (Lind, 2001). To exemplify, consider three perceptions of events: a manager attributes an increase in the promotion (high distributive justice), in a respectful manner (high interactional justice), and using consistent procedures (high procedural justice). Based on this evidence, the employee will decide whether his manager is a fair person (a judgment by a social entity) and whether he or she works for a fair organization (a judgment by a different social entity). This judgment was generated considering the three perceptions of events, somehow, integrated and combined (Cropanzano et al., 2001).

The integrative model, therefore, highlights the link between actions (events) and the generators of actions (social entities) in the evaluation of justice. Briefly, the elements can cause the event to be viewed as fair/unfair, this perception that may impact assessments of social entities (Cropanzano et al., 2001). This integration between the typologies of justice emphasizes that we should be less concerned about differentiating between types of justice and more concerned about understanding the consequences of justice events (Lind, 2001). 
Despite the understanding of the components of justice and their relational nature, research on justice suffers from deficiencies in its measurement and consistency, a fact that encouraged Colquitt (2001) to construct an indirect measurement scale based on seminal works in the literature on justice. More details can be seen in Illustration 7.

\begin{tabular}{|l|}
\hline \multicolumn{1}{|c|}{ Procedural Justice } \\
\hline Have you been able to express your views and feelings during those procedures used to arrive at your outcome? \\
\hline Have you had influence over the outcome arrived at by those procedures? \\
\hline Have those procedures been applied consistently? \\
\hline Have those procedures been free of bias? \\
\hline Have those procedures been based on accurate information? \\
\hline Have you been able to appeal the outcome arrived at by those procedures? \\
\hline Have those procedures upheld ethical and moral standards? \\
\hline \\
\hline Does your outcome reflect the effort you have put into your work? \\
\hline Is your outcome appropriate for the work you have completed? \\
\hline Does your outcome reflect what you have contributed to the organization? \\
\hline Is your outcome justified, given your performance? \\
\hline \\
\hline Has the authority figure who enacted the procedure treated you in a polite manner? \\
\hline Has he/she treated you with dignity? \\
\hline Has he/she treated you with respect? \\
\hline Has he/she refrained from improper remarks or comments? \\
\hline Has he/she been candid in his/her communications with you? \\
\hline Has he/she explained the procedures thoroughly? \\
\hline Were his/her explanations regarding the procedures reasonable? \\
\hline Has he/she communicated details in a timely manner? \\
\hline Has he/she seemed to tailor (his/her) communications to individuals' specific needs? \\
\hline \\
Source: Adapted from Colquitt (2001, p.389). \\
\hline
\end{tabular}

It is emphasized that, in Colquitt's (2001) perspective, interactional justice can be subdivided into interpersonal justice and informational justice. Therefore, in Illustration 7, the items that represent interactional justice cover the combination of items from these two types of justice (interpersonal and informational).

As highlighted by Bridoux and Stoelhorst (2014), organizations that develop justicebased stakeholder interactions tend to sustain their relationships. Relationships based on justice can foster an organizational ethos based on an open, closer, and honest exchange of relevant information, with a willingness to solve problems through collaboration and optimal trust (Cropanzano et al., 2001; Wicks, Berman, \& Jones, 1999). So, an organization perceived as fair is also perceived as more reliable and less likely to act opportunistically when it comes to the disclosure of confidential information.

When impartiality and justice are evident, stakeholders and organizations are more likely to reveal their utility functions to each other in order to create value together (Harrison, 
Bosse, \& Phillips, 2010). These benefits lead to a situation where, in the long run, organizations that treat their stakeholders fairly outperform those that do not (Hayibor, 2017).

An open innovation process suggests the existence of various sources of information, technologies, and knowledge, whether internal or external, that are relevant to the development and generation of innovations (Chesbrough, 2004). By accessing more sources, the organization increases its access to valuable knowledge and information for the innovation process (Leiponen \& Helfat, 2010). This access is facilitated by the company's fair relationships with its stakeholders (Bridoux \& Stoelhorst, 2014; Harrison, Bosse, \& Phillips, 2010).

At the same time, the fair treatment of stakeholders by the company, demonstrated through distributive, procedural, and interactional justice, has a cumulative effect on stakeholders, encouraging them to contribute positively more than they would if the company presents fair treatment in just a dimension of justice (Bosse, Phillips, \& Harrison, 2009).

Consequently, it is suggested that stakeholders' relationships based on justice (based on distributive justice, interactional justice and/or procedural justice) influence the likelihood that a company will have open innovation processes.

Hypothesis 2: Stakeholders' relationships based on justice are positively related to the development of open innovation.

Hypothesis 2a: Stakeholders' relationships based on distributive justice are positively related to the development of open innovation.

Hypothesis 2b: Stakeholders' relationships based on interactional justice are positively related to the development of open innovation.

Hypothesis 2c: Stakeholders' relationships based on procedural justice are positively related to the development of open innovation.

\subsection{Stakeholders' Relationships Based on Temporal Consistency and Open Innovation}

Members of an organization should be consistent in how they treat their stakeholders (Jones, Harrison, \& Phelps, 2018), as the consistency of various management practices is preferred by employees and other stakeholder groups over inconsistency (Wang \& Choi, 2013). By maintaining consistent behavior over time, the organization creates standards that allow stakeholders to observe how the company interacts with different groups, and thus decide when and how to engage with it (Brickson, 2007). Therefore, the organization interacts with 
stakeholders through consistent standards (Bosse \& Coughlan, 2016; Brickson, 2007; Jones, Harrison, \& Phelps, 2018).

Once formed, relationship patterns serve as drivers by which organizations affect stakeholders (Brickson, 2007). The rule of consistency over time suggests that once such standards are established, a sudden or marked deviation from them will be perceived as a violation of fair procedures (Leventhal, 1980). When there is inconsistent behavior in its interactions and relationships, the credibility and trust of stakeholders concerning the organization can be lost (Chen \& Miller, 2015). In the absence of established standards breaking, there is the so-called temporal consistency, which portrays the reliability of the treatment that a company does with its stakeholders over time (Wang \& Choi, 2013).

Temporal consistency facilitates the understanding of a company by its stakeholders. When a company's treatment of stakeholders varies considerably over time, there is so-called low temporal consistency. On the other hand, good temporal consistency indicates that the way the organization treats its stakeholders today strongly predicts how they might be treated tomorrow (Wang \& Choi, 2013).

Considering that consistent social practices are not easily replicable by competitors (Wang \& Choi, 2013), organizations become more competitive by presenting a consistent strategy for dealing with and treating their stakeholders, acquiring expertise in these practices, and thus facilitating their incorporation into the company's culture (Harrison, Bosse, \& Phillips, 2010). Therefore, it turns out that the temporal consistency of an organization's management decisions and practices is crucial to sustaining the contributions of stakeholders in the processes of creating joint value (Bridoux \& Stoelhorst, 2016; Bridoux \& Stoelhorst, 2014).

Building valuable and good stakeholder relationships requires consistent efforts over a long period (Hillman \& Keim, 2001; Wang \& Choi, 2013). This also requires a perception of quality from stakeholders, illustrating the extent to which stakeholders consider the organization's activities to be genuine and unintended (Berman et al., 1999; Jones, 1995). When a company treats its stakeholders consistently well, in good and bad times, stakeholders are more likely to consider the company's behavior as genuine and predictable (Lee et al., 2004; Wang \& Choi, 2013). These factors, therefore, reveal that stronger relationships between stakeholders and the organization are built by maintaining consistent behavior of the organization in repeated interactions, which strengthens the company's ability to gain support and cooperation from its stakeholders (Wang \& Choi, 2013).

Good temporal consistency when developing solid relationships with stakeholders also encourages internal and external stakeholders to strive to help the organization in implementing 
their knowledge assets and acquire knowledge more efficiently (Coff, 2003; Wang \& Choi, 2013).

The advantages obtained through temporal consistency of the organization's behavior concerning its stakeholders, including cooperation (Wang \& Choi, 2013), access to information (Harrison, Bosse, \& Phillips, 2010), and knowledge (Coff, 2003; Wang \& Choi, 2013), are relevant to the generation and development of open innovation (Chesbrough, 2012; Huang \& Li, 2017; Simeone, Secundo \& Schiuma, 2017). As highlighted in the literature, the various forms of cooperation between the organization and its stakeholders play a central and relevant role in the process and development of innovation (Fisher \& Qualls, 2018), acting to generate unique knowledge for the company in this process (Kazadi, Lievens, \& Mahr, 2016).

Therefore, the following hypothesis is proposed:

Hypothesis 3: Stakeholders' relationships based on temporal consistency are positively related to the development of open innovation.

Hypothesis 3a: Stakeholders' relationships based on temporal consistency of positive reciprocity are positively related to the development of open innovation.

Hypothesis 3b: Stakeholders' relationships based on temporal consistency of justice are positively related to the development of open innovation.

Considering the hypotheses explained, the conceptual model of this research is shown in Illustration 8.

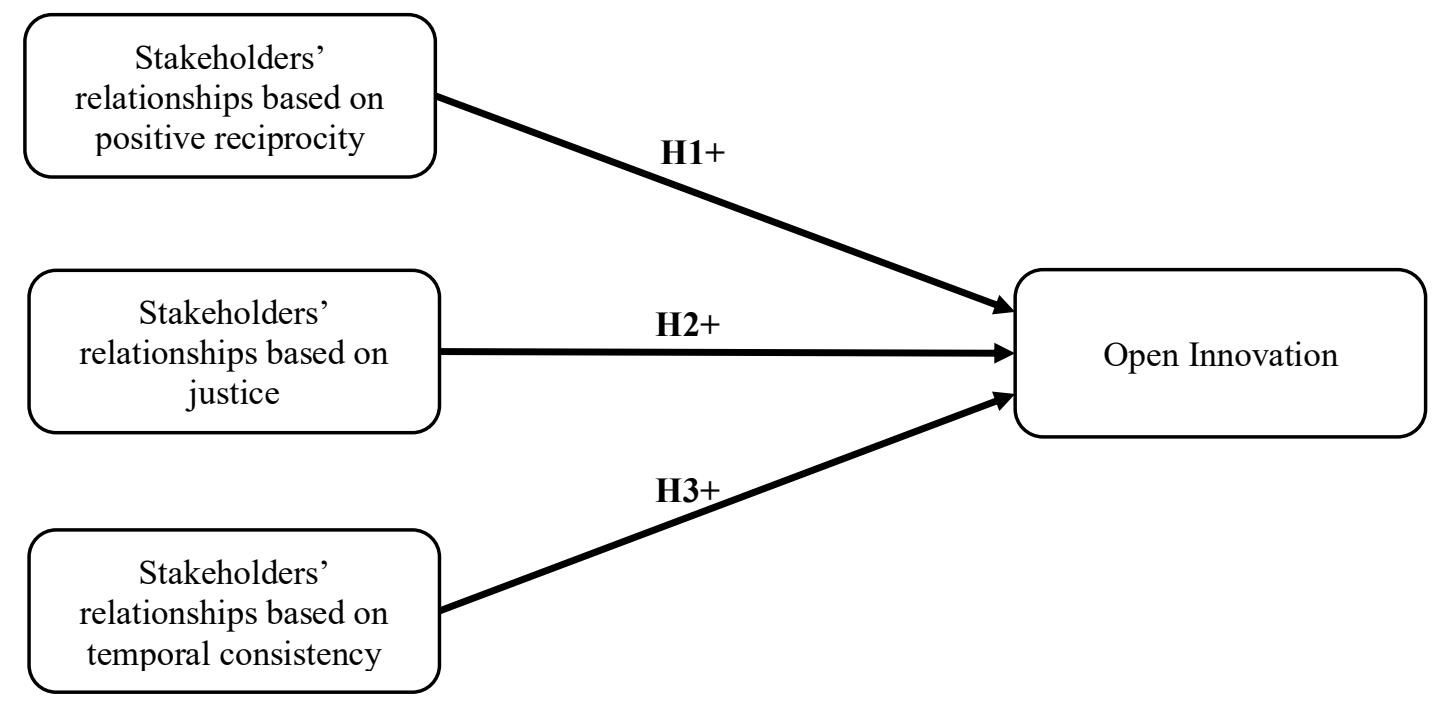

Illustration 8 - Research model.

Source: Author (2020). 


\section{METHODS}

This chapter briefly describes the methodological procedures adopted in this study. For a better clarification of these positions, the approach was divided into four topics. The first presents the characterization of the research, exhibiting an overview of how it was developed; the second presents the sample and data collection, describing how the sample was composed and from which sources the data were collected; the third topic presents the variables that were used in the research, describing them and explaining which concepts they represent; finally, the fourth topic describes the longitudinal logistic model and multinomial longitudinal logistic model, the fundamental statistical tools applied in the analysis.

\subsection{Research Characteristics}

This research fits into the positivist paradigm, as it considers reality as objective and separate from the researcher, being interested in the interrelationship of the objects they are studying and the operationalization of the concepts to be utilized (Collis \& Hussey, 2005).

It aims to explain the relationship between stakeholders' relationships and open innovation. Therefore, considering the purposes or objectives, it classifies as explanatory research, considering that it attempts to explain why two variables are related, as well as the reason for a phenomenon to occur and under what conditions (Collis \& Hussey, 2005; Sampieri, Collado, \& Lucio, 2013).

Regarding the approach to the problem, it is classified as quantitative. The quantitative approach, based on the hypothetical-deductive method, as explained by Sampieri, Collado, and Lucio (2013), is one that relies on numerical measurement, often using statistical techniques to answer research questions and test previously established hypotheses. In order to test the research hypotheses, the statistical techniques of longitudinal nonlinear logistic model and longitudinal logistic multinomial model were applied. Regarding data source, the data used are characterized as secondary data.

It is also classified as longitudinal research, as it analyzes the data on stakeholders' relationships and open innovation of Brazilian organizations from 2008 to 2017. This period was chosen due to the availability of ISE data, utilized to measure stakeholders' relationships. 


\subsection{Sample and Data Collection}

The population of this study comprises publicly traded companies listed on the São Paulo Stock Exchange (B3) and their subsidiaries. The sample was composed of São Paulo Stock Exchange companies responding to the Corporate Sustainability Index (ISE) questionnaire between 2008 and 2017. The final sample (110 companies, 710 observations) was reduced according to the availability of information. Those companies that presented the ISE questionnaire in at least two years of the analysis period were included in the sample.

The data regarding stakeholders' relationships, which use resources distributed to primary stakeholders (shareholders, customers, community, suppliers, and employees) as proxies, were collected from the ISE database. The ISE is a sustainability index that was created in 2005, inspired by indices adopted abroad, notably the Dow Jones Sustainability Index (DJSI). The questionnaire used to select the companies from the ISE portfolio was developed by the Sustainability Center of the Getúlio Vargas Foundation (FGV) with funding from the World Bank's International Finance Corporation (IFC) (ISE, 2018a).

ISE is a corporate sustainability benchmarking tool, aimed at companies listed on the B3, which deals with aspects such as economic efficiency, environmental balance, social justice, corporate governance, commitment to sustainable development, transparency and accountability, in addition to performance in the economic and financial, social, environmental and climate businesses. The questionnaire has 7 dimensions, with 28 indicators and 300 questions (BM\&FBovespa, 2018). Despite GRI and Integrated Reporting recognition and widespread use as meaningful sustainability communication and disclosure tools (Boiral \& Henri, 2017; Stacchezzini, Melloni, \& Lai, 2016), ISE was selected considering the reliability of its data, generated by the ISE demand that companies respondents provide evidential documentation of the information in the questionnaire, assuming responsibility for it before the Brazilian Securities Commission (BM\&FBovespa, 2018).

The data regarding innovation were obtained from the database of the National Institute for Intellectual Property (INPI), the federal agency responsible for the improvement, dissemination, and management of the Brazilian system for granting and guaranteeing intellectual property rights to industry (INPI, 2018). Data from the period from 2008 to 2018 were gathered, also covering 3-year and 5-year lags, seeking to capture the effect of stakeholders' relationships on open innovation.

The 3-year lag is applied following international literature that treats this temporal lag as one of the most used lags when analyzing innovation as a dependent variable (Fallah \& 
Lechler, 2008; Gerken, Moehrle, \& Walter, 2015; Park, 2015). When searching for data on the patent granting period for the initial period of the data analysis of this research, it was possible to locate INPI reports with this information from 2011. In that year, the patent granting period in Brazil was 5.4 years (INPI, 2012). Because of this, the present research also used the 5-year lag.

\subsection{Measurement of Analyzed Variables}

In order to test the hypotheses of the present research, the variables open innovation and stakeholders' relationships were measured. Stakeholders' relationships are operationally defined as interactions between two parties that encourage each party involved to experience emotions, establish some form of a psychological bond, and motivate those involved to take action on behalf of the other party (Bosse \& Coughlan, 2016). The proxies for the different types of stakeholders' relationships presented in the hypotheses were measured using the ISE questionnaire.

\begin{tabular}{|c|c|c|}
\hline Category & Themes & ISE 2017 Questions \\
\hline \multirow[t]{3}{*}{ Ethics } & Conformity & ECO 16, ECO 17, GOV 11, SOC 41.1, SOC 41.3 \\
\hline & Human Rights & SOC 1, SOC 1.2, SOC 1.4 \\
\hline & Transparency & $\begin{array}{c}\text { GER 1.1, GER 1.2, ECO 11, ECO 12, SOC 1.1, } \\
\text { SOC 1.3, SOC 2.2, SOC } 27\end{array}$ \\
\hline Environment & $\begin{array}{l}\text { Environmental Management and } \\
\text { Planning }\end{array}$ & GER 1, GER 1.3, GER 1.3.1 \\
\hline \multirow[t]{2}{*}{ Finances } & Financial Performance & ECO 10, ECO 14, GOV 5 \\
\hline & Investment & NAT 1.2 \\
\hline \multirow[t]{5}{*}{$\begin{array}{l}\text { Stakeholders' } \\
\text { Treatment }\end{array}$} & Work Conditions & $\begin{array}{c}\text { SOC } 8, \text { SOC } 9, \text { SOC } 11, \text { SOC } 20, \text { SOC } 21, \text { SOC } \\
22, \text { SOC } 23, \text { SOC } 25, \text { SOC } 26, \text { SOC } 29\end{array}$ \\
\hline & Community Management & SOC 15, SOC 15.1, SOC 15.2, SOC 15.4 \\
\hline & Supplier Management & SOC 35, SOC 35.1, SOC 37 \\
\hline & $\begin{array}{l}\text { Stakeholder Management and } \\
\text { Institutional Relations }\end{array}$ & SOC 1.3 .1 \\
\hline & Customer Relationship & $\begin{array}{c}\text { SOC 4, SOC 5, SOC 5.1, SOC 18.1, SOC 18.2, } \\
\text { SOC } 18.3, \text { SOC } 18.4\end{array}$ \\
\hline \multirow[t]{2}{*}{ Management } & Governance & $\begin{array}{l}\text { GOV 4, GOV 24, GOV 26, GOV 28, GOV } 32, \\
\text { GOV } 34\end{array}$ \\
\hline & $\begin{array}{l}\text { Quality and Safety of Products } \\
\text { and Services }\end{array}$ & NAT 1 \\
\hline
\end{tabular}

Illustration 9 - Questions used for different types of stakeholders' relationships. Source: Based on Barbosa (2019).

Fifty-five questions were used related to the following dimensions: general, social, nature of the product, corporate governance, and economic and financial. These questions were selected because they were present in the questionnaire throughout the period analyzed (2008- 
2017). The indicators were classified into material themes and categories according to the framework developed by Barbosa (2019). It is considered that the actions of companies, demonstrated through the ISE, meet the demands of various groups, especially all primary stakeholders, therefore, applying a synergistic view (Barbosa, 2019; Garcia-Castro \& Francoeur, 2016; Tantalo \& Priem, 2016). In this sense, the present study considers that all the primary stakeholders of an organization experience equal treatment, receiving the same amount of value. The selected ISE indicators, as well as their respective categories and themes, are shown in Illustration 9.

Values were attributed to the alternatives for the selected questionnaire questions, calculating the score per year, considering the value distributed by the company to stakeholders. The score ranges from 0 to 1 . By distributing value to its stakeholders, the company demonstrates its concern for them, aiming to build relationships with those stakeholders.

To measure the stakeholders' relationships based on positive reciprocity, one of the independent variables of the present study, the distribution of total resources to primary stakeholders was used as a proxy. Stakeholders' relationships based on positive reciprocity are understood in the present research as interactions between two parties that encourage actions that are seen as friendly and signs of goodwill reciprocity (Bosse \& Coughlan, 2016; Liu et al., 2018; Swärd, 2016).

Thirty-four questions were used, as observed in Illustration 10, obtaining a score for the stakeholders' relationships based on positive reciprocity for each company. This score was obtained by adding up all the positive answers, which was divided by the maximum score if the company answered positively to all questions.

\begin{tabular}{|c|c|c|}
\hline Category & Themes & ISE 2017 Questions \\
\hline \multirow[t]{2}{*}{ Ethics } & Human Rights & SOC 1, SOC 1.2, SOC 1.4 \\
\hline & Transparency & GER 1.2, ECO 11, ECO 12, SOC 2.2 \\
\hline Environment & $\begin{array}{l}\text { Environmental Management and } \\
\text { Planning }\end{array}$ & GER 1, GER 1.3, GER 1.3.1 \\
\hline \multirow[t]{2}{*}{ Finances } & Financial Performance & GOV 5 \\
\hline & Investment & NAT 1.2 \\
\hline \multirow[t]{4}{*}{$\begin{array}{l}\text { Stakeholders' } \\
\text { Treatment }\end{array}$} & Work Conditions & $\begin{array}{c}\text { SOC 20, SOC 21, SOC 22, SOC } 23, \text { SOC } \\
25, \text { SOC } 26\end{array}$ \\
\hline & Community Management & SOC 15, SOC 15.1, SOC 15.2, SOC 15.4 \\
\hline & Supplier Management & SOC 35, SOC 35.1, SOC 37 \\
\hline & Customer Relationship & SOC 4, SOC 18.2 \\
\hline \multirow[t]{2}{*}{ Management } & Governance & $\begin{array}{c}\text { GOV 4, GOV 24, GOV 26, GOV 28, GOV } \\
\text { 32, GOV } 34\end{array}$ \\
\hline & $\begin{array}{l}\text { Quality and Safety of Products and } \\
\text { Services }\end{array}$ & NAT 1 \\
\hline
\end{tabular}

Illustration 10 - Questions used to measure the stakeholders' relationships based on positive reciprocity. Source: Based on Barbosa (2019). 


$$
R e c=\frac{\sum \text { affirmative answers of positive reciprocity }}{\text { Maximum score for positive reciprocity }}
$$

In turn, the proxy for the stakeholders' relationships based on justice, which is an independent variable of this study, was the average score of the sum of the stakeholders' relationships based on distributive justice, the stakeholders' relationships based on interactional justice, and the stakeholders' relationships based on procedural justice. Stakeholders' relationships based on justice are understood to be interactions between two parties that encourage actions perceived as ethically and morally correct in terms of resource distribution, interpersonal interaction, and/or process establishment (Bosse \& Coughlan, 2016; Bosse, Phillips, \& Harrison, 2009; Cropanzano \& Ambrose, 2015; Cropanzano et al., 2001).

To measure each of these relationships, it was used the framework developed by Colquitt (2001), selecting the ISE questions that represent each item of the different types of justice. In order to increase the validity of the selection of questions and decrease its subjectivity, the framework was presented, tested and analyzed by two Stakeholder Theory experts, between $11 / 11 / 2019$ and 11/15/2019, who agreed with the selection (83\% agreement level), suggesting high levels of reliability (Weber, 1990). Illustration 11 shows the questions selected to represent stakeholders' relationships based on justice. In all, twenty-one questions were selected.

\begin{tabular}{|c|c|}
\hline Distributive Justice & ISE 2017 \\
\hline $\begin{array}{l}\text { Is your (outcome) appropriate for the work you have } \\
\text { completed? }\end{array}$ & \multirow{3}{*}{ ECO 10; ECO 14; SOC 11; SOC 27; SOC 29} \\
\hline $\begin{array}{c}\text { Does your (outcome) reflect what you have contributed } \\
\text { to the organization? }\end{array}$ & \\
\hline Is your (outcome) justified, given your performance? & \\
\hline Interactional Justice & ISE 2017 \\
\hline $\begin{array}{l}\text { Has the authority figure who enacted the procedure } \\
\text { been candid in his/her communications with you? }\end{array}$ & \multirow{2}{*}{ GER 1.1; SOC 1.1, SOC 1.3; SOC 1.3.1 } \\
\hline $\begin{array}{l}\text { Has the authority figure who enacted the procedure } \\
\text { explained the procedures thoroughly? }\end{array}$ & \\
\hline Procedural Justice & ISE 2017 \\
\hline $\begin{array}{l}\text { Have you been able to express your views and feelings } \\
\text { during those procedures used to arrive at your } \\
\text { outcome? }\end{array}$ & \multirow{2}{*}{$\begin{array}{c}\text { ECO 16; ECO 17; GOV 11; SOC 5; SOC 5.1; SOC } \\
\text { 8; SOC 9; SOC 18.1; SOC } 18.3 ; \text { SOC 18.4; SOC } \\
41.1 ; \text { SOC } 41.3\end{array}$} \\
\hline $\begin{array}{l}\text { Have those procedures been free of bias? } \\
\text { Have those procedures upheld ethical and moral } \\
\text { standards? }\end{array}$ & \\
\hline
\end{tabular}

Illustration 11 - Items for measuring the stakeholders' relationships based on justice.

Source: Author (2020) 


$$
\begin{gathered}
\text { JDis }=\frac{\sum \text { affirmative answers of distributive justice }}{\text { Maximum score for distributive justice }} \\
\text { JInt }=\frac{\sum \text { affirmative answers of interactional justice }}{\text { Maximum score for interactional justice }} \\
\text { JPro }=\frac{\sum \text { affirmative answers of procedural justice }}{\text { Maximum score for procedural justice }} \\
\text { Jus }=\frac{\sum \text { Dis., JInt. and JProc. }}{3}
\end{gathered}
$$

Stakeholders' relationships based on temporal consistency was proxied by the annual variation in both stakeholders' relationships based on positive reciprocity and stakeholders' relationships based on justice. Operationally, stakeholders' relationships based on temporal consistency are understood as the interaction between two parties that encourages actions that set and illustrate stable patterns (Bosse \& Coughlan, 2016; Brickson, 2007; Jones, Harrison, \& Phelps, 2018). The following formulas were used:

$$
\begin{aligned}
& \text { Consistency }_{r e c}=\operatorname{Rec}_{t}-\operatorname{Rec}_{t-1} \\
& \text { Consistency }_{j u s}=J u s_{t}-J u s_{t-1}
\end{aligned}
$$

Open innovation is considered as the dependent variable of the study and operationally refers to a process whereby an idea, object, practice, technology, or process is created, reinvented, developed, disseminated, approved, and used - having been created through various internal sources and/or acquired from external sources (Ram, Cui \& Wu, 2010).

In order to measure whether an organization had open innovation, the dependent variable of this study, data were collected from the website of the National Institute of Industrial Property (INPI), showing the presence or absence of patents. Despite their limitations, patentbased indicators are widely used and accepted proxies in research to measure innovation (Baba, Shichijo \& Sedita, 2009; Guan \& Liu, 2016). Unlike other innovation proxies, such as R\&D expenditure, number of patents citations, or sales revenues of R\&D projects (Quintane et al., 2011), the presence of patents and analysis of their information allow classify the innovation as closed or open innovation. Considering that, the patents found in INPI were analyzed, identifying if different organizations filed them.

The data collected from the website, related to patents of organizations filed in the years from 2008 to 2018, were coded as follows: for years when organizations filed a patent with depositors from different organizations, code 1 was used (presents open innovation); for years when organizations have patents with depositors from only one organization, code 0 was used 
(presents closed innovation). In turn, for information that includes the presence or not of innovation, data were coded as follows: for the years in which organizations did not have a patent, code 0 was used (null innovation); for years when organizations had patents with applicants from only one organization, code 1 was used (closed innovation); for years when organizations had patents with applicants from different organizations, code 2 was used (open innovation).

The control variable was the size, whose proxy was the logarithm of total assets, which was collected from the Economática ${ }^{\circledR}$ database. Studies in the field of innovation propose that larger firms have more resources, better in-house $R \& D$, larger knowledge bases and scale to generate more innovations, and are better prepared to participate in open innovation (CanoKollman, Hamilton III, \& Mudambi, 2017; Chen, Vanhaverbeke, \& Du, 2016; Wang, Cheng, \& Shen, 2015).

A synthesis of the variables (dependent and independent) utilized in the research is shown in Illustration 12, which contains the proxies used to represent each variable and the source of each one.

\begin{tabular}{|c|c|c|c|}
\hline Variable & Classification & Proxy & Source \\
\hline Innovation & Dependent & $\begin{array}{c}\text { Open innovation - patent presence with depositors } \\
\text { from more than one organization; closed } \\
\text { innovation - patent presence with depositors from } \\
\text { only one organization; null innovation - no patent. }\end{array}$ & INPI \\
\hline $\begin{array}{c}\text { Stakeholders' } \\
\text { relationships based on } \\
\text { positive reciprocity }\end{array}$ & Independent & $\begin{array}{c}\text { Goodwill reciprocity - total resources distributed } \\
\text { by the company to stakeholders divided by the } \\
\text { maximum possible score. }\end{array}$ & ISE \\
\hline $\begin{array}{c}\text { Stakeholders' } \\
\text { relationships based on } \\
\text { justice }\end{array}$ & Independent & $\begin{array}{c}\text { Average of the sum of distributive, interactional } \\
\text { and procedural justice distributed by the } \\
\text { organization }\end{array}$ & ISE \\
\hline $\begin{array}{c}\text { Stakeholders' } \\
\text { relationships based on } \\
\text { temporal consistency }\end{array}$ & Independent & $\begin{array}{c}\text { Annual variation in relationships based on positive } \\
\text { reciprocity and based on justice over the analysis } \\
\text { period }\end{array}$ & ISE \\
\hline Size & Control & Natural logarithm of total assets & Economática \\
\hline \multicolumn{2}{|l|}{ Illustration 12 - Summary of the variables used in the research. } \\
Source: Author (2020).
\end{tabular}

Succeeding, the procedure used to analyze the data and test the hypotheses, the techniques of longitudinal logistic model and multinomial longitudinal logistic model are described. The purpose of these types of analyzes, their underlying assumptions and models are presented. 


\subsection{Data Analysis}

According to the characteristics of the innovation variable, with its categories, two data analysis techniques were used. Including data about null innovation, closed innovation, and open innovation, the dependent variable is characterized as qualitative data with polytomous values (Pforr, 2014). From this perspective, the technique used was the multinomial logistic nonlinear longitudinal model. Pforr (2014) highlights that the multinomial logistic longitudinal model can be estimated through pooled multinomial logistic estimates (POMLogit), multinomial logistic estimates with random effects (REMLogit), and multinomial logistic estimates with fixed effects (FEMLogit). The choice of the most appropriate estimation is made through the significance analysis of the models and the log-likelihood analysis. The data were tested using the Stata ${ }^{\circledR} 13$ software.

Due to the existence of three response categories $(0,1$, and 2$)$, category 0 - null innovation - was used as a reference. Closed innovation is represented by category 1, and open innovation is represented by category 2 . In order to evaluate the probability $p_{2}$ of occurrence of event 2 (open innovation) at time $t$ for particular individual $i$, the following equation of the logistic multinomial longitudinal model was used:

$$
p_{2 i t}=\frac{e^{\left(\alpha_{2 i}+\beta_{12} \text { Relationship }_{2 i t}+\beta_{22} \text { Size }_{2 i t}\right)}}{1+e^{\left(\alpha_{1 i}+\beta_{11} \text { Relationship }_{1 i t}+\beta_{21} \text { Size }_{1 i t}\right)+e^{\left(\alpha_{2 i}+\beta_{12} \text { Relationship }_{2 i t}+\beta_{22} \text { Size }_{2 i t}\right)}}}
$$

Where:

$\mathrm{p}_{2}=$ probability of occurrence of event 2 (open innovation) at time $t$ for a given individual $i$ Relationship = explanatory variable stakeholders' relationships, which varies between individuals (companies) and over time (study analysis period: 2008 to 2017).

$\beta_{\mathrm{i} 1}=$ coefficient of each explanatory variable, a parameter to be estimated, for event 1 (closed innovation).

$\alpha_{\mathrm{i} 1}=$ terms of intercept, which varies between individuals (companies), for event 1 (closed innovation).

$\beta_{\mathrm{i} 2}=$ coefficient of each explanatory variable, a parameter to be estimated, for event 2 (open innovation).

$\alpha_{\mathrm{i} 2}=$ terms of intercept, which varies between individuals (companies), for event 2 (open innovation).

Size $=$ natural logarithm of the total assets of each company. 
In terms of the first hypothesis $\left(\mathrm{H}_{1}\right)$, the following equation was tested:

$$
p_{2 i t}=\frac{e^{\left(\alpha_{2 i}+\beta_{12} \text { Reciprocity }_{2 i t}+\beta_{22} \text { Size }_{2 i t}\right)}}{1+e^{\left(\alpha_{1 i}+\beta_{11} \text { Reciprocity }_{1 i t}+\beta_{21} \text { Size }_{1 i t}\right)+e^{\left(\alpha_{2 i}+\beta_{12} \text { Reciprocity }_{2 i t}+\beta_{22} \text { Size }_{2 i t}\right)}}}
$$

Where Reciprocity represents the explanatory variable stakeholders' relationships based on positive reciprocity, which varies between individuals (companies) and over time (research analysis period - 2008 to 2017).

In turn, for the second hypothesis $\left(\mathrm{H}_{2}\right)$, the following equation was tested:

$$
p_{2 i t}=\frac{e^{\left(\alpha_{2 i}+\beta_{12} \text { Justice }_{2 i t}+\beta_{22} \text { Size }_{2 i t}\right)}}{1+e^{\left(\alpha_{1 i}+\beta_{11} \text { Justice }_{1 i t}+\beta_{21} \text { Size }_{1 i t}\right)+e^{\left(\alpha_{2 i}+\beta_{12} \text { Justice }_{2 i t}+\beta_{22} \text { Size }_{2 i t}\right)}}}
$$

Where Justice represents the explanatory variable stakeholders' relationships based on justice, which varies between individuals (companies) and over time (research analysis period - 2008 to 2017).

Finally, the third hypothesis $\left(\mathrm{H}_{3}\right)$ was tested using the following equation:

$$
p_{2 i t}=\frac{e^{\left(\alpha_{2 i}+\beta_{12} \text { Consistency }_{2 i t}+\beta_{22} \text { Size }_{2 i t}\right)}}{1+e^{\left(\alpha_{1 i}+\beta_{11} \text { Consistency }_{1 i t}+\beta_{21} \text { Size }_{1 i t}\right)+e^{\left(\alpha_{2 i}+\beta_{12} \text { Consistency }_{2 i t}+\beta_{22} \text { Size }_{2 i t}\right)}}}
$$

Where Consistency represents the explanatory variable stakeholders' relationships based on temporal consistency, which varies between individuals (companies) and over time (research analysis period - 2008 to 2017).

Excluding data from the absence of innovation, the dependent variable becomes to be characterized as qualitative data with dichotomous values (Neuhaus, 1992). In this other scenario, the technique used was the longitudinal nonlinear logistic model estimated when the dependent variable is binary (0 or 1). According to Fávero and Belfiore (2017), the longitudinal logistic model can be estimated through Pooled Logit and Population-Average (PA) estimations, within the so-called GEE (Generalized Estimating Equations), and through fixed and random effects estimations. The choice of the most appropriate estimation is made through the significance analysis of the models and the log-likelihood analysis. Data were tested using the $\operatorname{Stata}{ }^{\circledR} 13$ software. 
In order to evaluate the probability $p$ of occurrence of the event (open innovation) at time $t$ for particular individual $i$, the following equation of the logistic longitudinal model was used:

$$
\ln \left(\frac{p_{i t}}{1-p_{i t}}\right)=\alpha_{i}+\beta_{1} \text { Relationship }{ }_{i t}+\beta_{2} \text { Size }_{i t}
$$

Which, when developed, comes to:

$$
p_{i t}=\frac{1}{1+e^{-\left(\alpha_{i}+\beta_{1}\right. \text { Relationship }} \text { it }^{\left.+\beta_{2} \text { Size }_{\text {it }}\right)}}
$$

Where:

p: probability of occurrence of the expected event (open innovation) at time $t$ for a given individual $i$

Relationship $=$ explanatory variable stakeholders' relationships, which varies between individuals (companies) and over time (study analysis period: 2008 to 2017).

$\beta_{\mathrm{i}}=$ coefficient of each explanatory variable, parameter to be estimated.

$\alpha_{i}=$ terms of the intercept that varies between individuals (companies).

Size $=$ natural logarithm of the total assets of each company.

In terms of the first hypothesis $\left(\mathrm{H}_{1}\right)$, the following equation was tested:

$$
p_{i t}=\frac{1}{1+e^{-\left(\alpha_{i}+\beta_{1} \text { Reciprocity }_{i t}+\beta_{2} \text { Size }_{i t}\right)}}
$$

Where Reciprocity represents the explanatory variable stakeholders' relationships based on positive reciprocity, which varies between individuals (companies) and over time (research analysis period - 2008 to 2017 ).

In turn, for the second hypothesis $\left(\mathrm{H}_{2}\right)$, the following equation was tested:

$$
p_{i t}=\frac{1}{\left.1+e^{-\left(\alpha_{i}+\beta_{1} \text { Justice }_{i t}+\beta_{2}\right. \text { Size }} \text { it }\right)}
$$

Where Justice represents the explanatory variable stakeholders' relationships based on justice, which varies between individuals (companies) and over time (research analysis period - 2008 to 2017).

Finally, the third hypothesis $\left(\mathrm{H}_{3}\right)$ was tested using the following equation: 


$$
p_{i t}=\frac{1}{1+e^{-\left(\alpha_{i}+\beta_{1} \text { Consistency }_{i t}+\beta_{2} \text { Size }_{i t}\right)}}
$$

Where Consistency represents the explanatory variable stakeholders' relationships based on temporal consistency, which varies between individuals (companies) and over time (research analysis period - 2008 to 2017). 


\section{RESULTS}

The results chapter was divided into two sections. First, a descriptive analysis of the data was performed, thus obtaining the characterization of the sample and variables over time and by an individual (company). Then, a multivariate analysis of the data was performed, testing the proposed hypotheses. It should be noted that in this section, two multivariate techniques (longitudinal logistic model and multinomial longitudinal logistic model) were carried out, in order to have a richer and more detailed view of the influence of the types of stakeholders' relationships on open innovation, under diverse perspectives.

\subsection{Descriptive Data Analysis}

The study sample comprised 110 companies, classified in nine different industries, as shown in Table 1. It can be observed that most of the sample is represented by companies operating in the utility sector (39\%). Following this, the most represented industries are: capital goods and services (15\%), basic materials (12\%), and financial (11\%).

Table 1 - Industries in the sample

\begin{tabular}{cccc}
\hline Industry & Observations & $\begin{array}{c}\mathrm{N}^{\mathbf{o}} \text { of } \\
\text { Companies }\end{array}$ & Percentual \\
\hline Capital goods and services & 118 & 17 & $15 \%$ \\
Consumer cyclical & 44 & 8 & $7 \%$ \\
Consumer noncyclical & 30 & 6 & $6 \%$ \\
Financial & 85 & 12 & $11 \%$ \\
Basic materials & 76 & 13 & $12 \%$ \\
Oil, gas and biofuels & 3 & 1 & $1 \%$ \\
Health & 12 & 4 & $4 \%$ \\
Communications & 29 & 6 & $5 \%$ \\
Utilities & 313 & 43 & $39 \%$ \\
\hline
\end{tabular}

Source: Research data.

The distribution of the number of companies per year can be seen in Table 2. As described in the methodology section, data were collected from the organizations from 2008 to 2017, totaling 710 observations.

Table 2 - Number of companies per year

\begin{tabular}{cc}
\hline Year & Companies \\
\hline 2008 & 59 \\
2009 & 67 \\
2010 & 72 \\
2011 & 84 \\
\hline
\end{tabular}


Source: Research data.

\begin{tabular}{ll}
\hline 2012 & 81 \\
2013 & 79 \\
2014 & 73 \\
2015 & 68 \\
2016 & 64 \\
2017 & 63 \\
\hline
\end{tabular}

As it is a data panel, the variables of interest in the present study (positive reciprocity, justice, temporal consistency) suffer variations in their values both between individuals (between variance) and over time for the same individual (within variance). These values can be seen in the Table 3 .

Table 3 - Descriptive statistics of independent variables

\begin{tabular}{|c|c|c|c|c|c|c|}
\hline Variable & & Mean & $\begin{array}{c}\text { Standard } \\
\text { Deviation } \\
\end{array}$ & Minimum & Maximum & Observations \\
\hline \multirow{3}{*}{ Positive reciprocity } & Overall & 0.61 & 0.16 & 0 & 0.91 & $\mathrm{~N}=710$ \\
\hline & Between & & 0.14 & 0.07 & 0.82 & $\mathrm{n}=110$ \\
\hline & Within & & 0.12 & 0.04 & 1.01 & \\
\hline \multirow{3}{*}{ Justice } & Overall & 0.56 & 0.19 & 0 & 0.91 & $\mathrm{~N}=710$ \\
\hline & Between & & 0.16 & 0.10 & 0.81 & $\mathrm{n}=110$ \\
\hline & Within & & 0.13 & 0.14 & 0.98 & \\
\hline \multirow{3}{*}{ Distributive justice } & Overall & 0.58 & 0.21 & 0 & 1 & $\mathrm{~N}=710$ \\
\hline & Between & & 0.17 & 0.14 & 0.82 & $\mathrm{n}=110$ \\
\hline & Within & & 0.15 & 0.11 & 1.06 & \\
\hline \multirow{3}{*}{ Interactional justice } & Overall & 0.58 & 0.29 & 0 & 1 & $\mathrm{~N}=710$ \\
\hline & Between & & 0.24 & 0 & 1 & $\mathrm{n}=110$ \\
\hline & Within & & 0.20 & 0.01 & 1.15 & \\
\hline \multirow{3}{*}{ Procedural justice } & Overall & 0.52 & 0.20 & 0 & 0.96 & $\mathrm{~N}=710$ \\
\hline & Between & & 0.14 & 0.14 & 0.77 & $\mathrm{n}=110$ \\
\hline & Within & & 0.15 & 0.04 & 0.92 & \\
\hline \multirow{3}{*}{$\begin{array}{l}\text { Temporal consistency of } \\
\text { positive reciprocity }\end{array}$} & Overall & 0.03 & 0.12 & -0.56 & 0.69 & $\mathrm{~N}=586$ \\
\hline & Between & & 0.08 & -0.39 & 0.31 & $\mathrm{n}=109$ \\
\hline & Within & & 0.11 & -0.56 & 0.63 & \\
\hline \multirow{3}{*}{$\begin{array}{l}\text { Temporal consistency of } \\
\text { justice }\end{array}$} & Overall & 0.03 & 0.14 & -0.64 & 0.64 & $\mathrm{~N}=584$ \\
\hline & Between & & 0.08 & -0.41 & 0.32 & $\mathrm{n}=109$ \\
\hline & Within & & 0.13 & -0.59 & 0.64 & \\
\hline
\end{tabular}

Source: Research data.

According to Table 3, we observed that the variables of stakeholders' relationships based on positive reciprocity, based on justice, based on distributive justice, and based on interactional justice demonstrate a greater between variance, demonstrating that for the sample organizations there is a more significant change in these relationships between different organizations, and a smaller variation of each of these relationships for the same company over the years analyzed.

Concerning stakeholders' relationships based on procedural justice, based on temporal consistency of positive reciprocity, and based on temporal consistency of justice, there is a greater within variance, demonstrating that for the sample organizations there is a more 
significant change in these variables over time for each company, a variation that is greater than the variation between different companies in the same period.

Analyzing the innovation, the descriptive data about null innovation, closed innovation, and open innovation can be seen in Table 4.

Table 4 - Observation frequency in terms of innovation

Source: Research data.

\begin{tabular}{cccc}
\hline Innovation & Year 0 & Year +3 & Year +5 \\
\hline Null innovation & 649 & 651 & 663 \\
Closed innovation & 34 & 33 & 26 \\
Open innovation & 27 & 26 & 21 \\
\hline Total & 710 & 710 & 710 \\
\hline
\end{tabular}

Data reveal that over the years analyzed, the Brazilian companies studied have a low percentage of innovation, on average $7.8 \%$, demonstrating that this phenomenon has low insertion among the large Brazilian companies that compose the sample. Focusing on the characterization of the innovation of the organizations analyzed, there is a more significant presence of closed innovation. Open innovation is restricted, on average, to $3.5 \%$ of the observations.

Table 5 - Distribution of observations in terms of innovation by industry

\begin{tabular}{cccc}
\hline Industry & Null innovation & Closed innovation & Open innovation \\
\hline Capital goods and services & 113 & 4 & 1 \\
Consumer cyclical & 44 & 0 & 0 \\
Consumer noncyclical & 19 & 8 & 3 \\
Financial & 83 & 2 & 0 \\
Basic materials & 53 & 9 & 14 \\
Oil, gas and biofuels & 0 & 1 & 2 \\
Health & 12 & 0 & 0 \\
Communications & 27 & 2 & 0 \\
Utilities & 298 & 8 & 7 \\
\hline
\end{tabular}

Source: Research data.

Table 5 shows that four of the nine industries do not present open innovation in any of their observations. These sectors are: i) consumer cyclical, ii) financial, iii) health, and iv) communications. Among the five remaining industries, the following stand out: the oil, gas, and biofuels sector, where $67 \%$ of the observations show open innovation; the basic materials sector, where $18 \%$ of the observations show open innovation; and the consumer noncyclical sector, where $10 \%$ of the observations show open innovation. It is also noteworthy that the basic materials and oil, gas, and biofuels sectors were the only ones that presented a higher percentage 
of open innovation than closed innovation, and they can thus be considered the sectors with the most open innovation in the research sample.

Table 6 - Means of stakeholders' relationships for innovation category

\begin{tabular}{cccc}
\hline Mean & Null innovation & Closed innovation & Open innovation \\
\hline Positive reciprocity & 0.61 & 0.60 & 0.69 \\
Justice & 0.56 & 0.57 & 0.59 \\
Distributive justice & 0.57 & 0.63 & 0.61 \\
Interactional justice & 0.58 & 0.60 & 0.60 \\
Procedural justice & 0.52 & 0.49 & 0.55 \\
Temporal consistency of positive & 0.03 & -0.03 & 0.02 \\
reciprocity & & -0.01 & 0.02 \\
Temporal consistency of justice & 0.03 & &
\end{tabular}
Source: Research data.

Table 6 demonstrates that stakeholders' relationships based on positive reciprocity, based on justice, based on interactional justice, and based on procedural justice, have the highest average in terms of organizations that develop open innovation. These data are aligned with the proposed hypotheses. In terms of temporal consistency, in absolute values, there is less variation in the temporal consistency of positive reciprocity in organizations that develop open innovation, thus also showing a possible alignment between these data and hypothesis $3 \mathrm{a}$. However, regarding the temporal consistency of justice, there is a smaller variation in absolute terms in organizations that present closed innovation. In terms of stakeholders' relationships based on distributive justice, a higher average is observed in organizations that develop closed innovation.

Table 7 - Means of stakeholders' relationships per year

\begin{tabular}{|c|c|c|c|c|c|c|c|c|c|c|}
\hline Mean & 2008 & 2009 & 2010 & 2011 & 2012 & 2013 & 2014 & 2015 & 2016 & 2017 \\
\hline Positive reciprocity & 0.53 & 0.54 & 0.55 & 0.47 & 0.55 & 0.67 & 0.69 & 0.70 & 0.71 & 0.75 \\
\hline Justice & 0.49 & 0.48 & 0.51 & 0.45 & 0.50 & 0.59 & 0.58 & 0.63 & 0.70 & 0.70 \\
\hline Distributive justice & 0.47 & 0.46 & 0.57 & 0.49 & 0.55 & 0.63 & 0.60 & 0.65 & 0.72 & 0.68 \\
\hline Interactional justice & 0.47 & 0.46 & 0.50 & 0.42 & 0.48 & 0.64 & 0.61 & 0.68 & 0.78 & 0.81 \\
\hline Procedural justice & 0.52 & 0.51 & 0.47 & 0.44 & 0.47 & 0.50 & 0.53 & 0.58 & 0.60 & 0.61 \\
\hline $\begin{array}{l}\text { Temporal consistency of } \\
\text { positive reciprocity }\end{array}$ & - & 0.04 & 0.02 & -0.07 & 0.07 & 0.11 & 0.03 & $\begin{array}{c}- \\
0.002\end{array}$ & 0.01 & 0.03 \\
\hline Temporal consistency of justice & - & 0.02 & 0.06 & -0.04 & 0.03 & 0.08 & -0.02 & 0.05 & 0.06 & $\begin{array}{c}- \\
0.001\end{array}$ \\
\hline
\end{tabular}

Source: Research data.

Table 7 exhibits the average values of the stakeholders' relationships exhibit in the years investigated. From a first exploratory analysis of the behavior of the variables, it is observed that, in most years of the period examined, the stakeholders' relationships based on positive reciprocity is the explanatory variable that has the highest average. Subsequent, the variables 
with the highest average are stakeholders' relationships based on distributive justice and stakeholders' relationships based on interactional justice.

Table 8 shows the mean of the different types of stakeholders' relationships in each industry and the total mean for all companies in the sample.

Table 8 - Mean values of stakeholders' relationships by industry

\begin{tabular}{cccccccc}
\hline Industry & Rec & Jus & JDis & JInt & JPro & T Rec & T Jus \\
\hline Capital goods and services & 0.60 & 0.57 & 0.62 & 0.52 & 0.56 & 0.04 & 0.04 \\
Consumer cyclical & 0.56 & 0.51 & 0.55 & 0.47 & 0.51 & 0.06 & 0.06 \\
& & & & & & & \\
Consumer noncyclical & 0.61 & 0.58 & 0.62 & 0.56 & 0.55 & 0.01 & 0.01 \\
Financial & 0.66 & 0.56 & 0.56 & 0.61 & 0.52 & 0.04 & 0.03 \\
Basic materials & 0.59 & 0.50 & 0.50 & 0.47 & 0.52 & 0.03 & 0.01 \\
Oil, gas and biofuels & 0.70 & 0.56 & 0.76 & 0.53 & 0.39 & 0.00 & -0.01 \\
Health & 0.54 & 0.51 & 0.57 & 0.39 & 0.56 & 0.02 & 0.04 \\
Communications & 0.56 & 0.46 & 0.51 & 0.48 & 0.37 & -0.01 & 0.01 \\
Utilities & 0.62 & 0.59 & 0.59 & 0.65 & 0.52 & 0.02 & 0.03 \\
\hline
\end{tabular}

Note: Rec. $=$ positive reciprocity; Jus $=$ justice; JDis $=$ distributive justice; JInt $=$ interactional justice; JPro $=$ procedural justice; $T \_R e c=$ temporal consistency of positive reciprocity; $T$ J Jus $=$ temporal consistency of justice. Source: Research data.

According to Table 8 , the sectors that have the highest means for stakeholders' relationships based on reciprocity are: (i) oil, gas and biofuels, (ii) financial, and (iii) utilities. Stakeholders' relationships based on justice present the highest mean in the sectors: (i) utilities, (ii) consumer noncyclical, and (iii) capital goods and services. Stakeholders' relationships based on distributive justice have the highest mean in the sectors: (i) oil, gas and biofuels, (ii) consumer noncyclical, and (iii) capital goods and services. As for stakeholders' relationships based on interactional justice, it presents the highest mean in the sectors: (i) utilities, (ii) financial, and (iii) consumer noncyclical. Finally, stakeholders' relationships based on procedural justice have the highest mean in the sectors: (i) health, (ii) capital goods and services, and (iii) consumer noncyclical.

In terms of stakeholders' relationships based on temporal consistency of positive reciprocity, the sectors that showed the least variation, in absolute numbers, were: (i) oil, gas and biofuels, (ii) consumer noncyclical, and (iii) communications. Finally, in terms of stakeholders' relationships based on temporal consistency of justice, the sectors that showed the least variation, in absolute numbers, were: (i) basic materials, (ii) consumer noncyclical, (iii) communications, and (iv) oil, gas and biofuels.

In order to identify whether such means between distinct sectors are statistically different, the One-way ANOVA test was performed. Means with statistically relevant differences are hatched in Table 8 . The means of stakeholders' relationships based on the 
temporal consistency of positive reciprocity and stakeholders' relationships based on temporal consistency of justice did not show statistically significant differences for distinct sectors. In terms of stakeholders' relationships based on positive reciprocity, a significant difference (pvalue of 0.048 ) was found between the means of the consumer cyclical sector and financial sector. Finally, regarding stakeholders' relationships based on justice, there is a significant difference (p-value of 0.013 ) between the means of the communications sector and utilities sector.

Specifically, regarding the relationships with stakeholders based on the different types of justice, we have: (i) regarding distributive justice, a significant difference (p-value 0.006) is noted between means of the industrial goods sector and the basic materials sector, significant difference (p-value 0.027 ) between means of the basic materials sector and utilities sector; (ii) regarding interactional justice, a significant difference ( $p$-value 0.001) is noted between means

of the capital goods and services sector and utilities sector, significant difference ( $p$-value 0.003 ) between means of the consumer cyclical sector and utilities sector, and significant difference ( $p$-value 0.000) between means of the basic materials sector and utilities sector; (iii) in terms of procedural justice, there is a significant difference ( $p$-value 0.000 ) between means of the capital goods and services sector and communications sector, a significant difference ( $\mathrm{p}$ value 0.013 ) between means of the consumer noncyclical sector and communications sector, significant difference ( $p$-value 0.022) between means of the financial sector and communications sector, significant difference ( $p$-value 0.023 ) between means of the basic materials sector and communications sector, and significant difference (p-value 0.006) between means of the utilities sector and communications sector.

It is noteworthy that such data should be analyzed with caution, given that the distribution of companies by sectors is diversified, with very different frequencies. However, given the little differentiation of independent variables between sectors, this control variable was not used in the models of multivariate data analysis.

\subsection{Multivariate Data Analysis}

This section presents the statistical relationships between the variables of interest and the multivariate analysis of the data, subdivided according to the analysis reference point. In the first subsection, the relations between the variables of interest are presented, having closed innovation as the reference category for open innovation. Therefore, the longitudinal logistic model is applied as an analysis technique. In the second subsection, relations between the 
variables of interest are presented, with null innovation as the reference category for open innovation, in addition to the presence of the closed innovation category. In this case, therefore, the longitudinal multinomial logistic model analysis technique is adopted.

\subsubsection{Longitudinal logistic model}

In this multivariate analysis, the dependent variable presented two categories: it presents closed innovation (category represented by the number 0 ); presents open innovation (category represented by number 1). Models were estimated for three different periods: (i) model without time lag - Year 0; (ii) model in which the dependent variable has a 3-year time lag - Year 3; (iii) model in which the dependent variable shows a 5-year time lag - Year 5.

\subsubsection{Estimation of hypothesis 1}

To estimate hypothesis 1, the logit, pooled average (P.A.), random effects (R.E.), and fixed effects (F.E.) models were performed. The models that revealed statistical significance are shown in Table 9.

Table 9 - Estimations of hypothesis 1 in the longitudinal logistic model

\begin{tabular}{|c|c|c|c|c|c|c|}
\hline \multirow{2}{*}{ Variable } & \multicolumn{3}{|c|}{ Year 0} & \multicolumn{3}{|c|}{ Year 5} \\
\hline & Logit & P.A. & R.E. & Logit & P.A. & R.E. \\
\hline Stakeholders' relationships based on & $5.75 * *$ & $7.98 * *$ & $10.79 * *$ & $9.53 * * *$ & $9.41 * * *$ & $11.83 * *$ \\
\hline positive reciprocity & $(2.60)$ & $(3.21)$ & $(5.12)$ & $(3.02)$ & $(3.11)$ & $(5.43)$ \\
\hline & 0.22 & 0.06 & 0.06 & $-0.46^{* *}$ & - & -0.69 \\
\hline Size & $(0.23)$ & $(0.23)$ & $(0.32)$ & $(0.20)$ & $\begin{array}{c}0.62 * * * \\
(0.22)\end{array}$ & $(0.47)$ \\
\hline Constant & $\begin{array}{l}-7.85 \\
(4.83)\end{array}$ & $\begin{array}{l}-6.78 \\
(5.48)\end{array}$ & $\begin{array}{c}-8.75^{* *} \\
(5.81)\end{array}$ & $\begin{array}{c}1.52 \\
(3.42)\end{array}$ & $\begin{array}{c}4.11 \\
(3.62)\end{array}$ & $\begin{array}{c}3.76 \\
(6.48)\end{array}$ \\
\hline Log-likelihood & -37.51 & & -35.09 & -25.40 & & -25.05 \\
\hline N. obs. & 61 & 61 & 61 & 47 & 47 & 47 \\
\hline N. groups & 25 & 25 & 25 & 25 & 25 & 25 \\
\hline Prob. $>$ chi $^{2}$ & 0.084 & 0.023 & 0.028 & 0.002 & 0.001 & 0.089 \\
\hline Pseudo-R $^{2}$ & $10.43 \%$ & & & $21.4 \%$ & & \\
\hline Rho & & & 0.468 & & & 0.261 \\
\hline
\end{tabular}

With closed innovation as the reference category, and establishing the statistical significance of the model as a 5\% cut, it can be noted that stakeholders' relationships based on positive reciprocity are relevant in the period without time lag and in the period with a 5-year temporal lag. 
In the model in which the dependent variable was tested without time lag, three estimates were considered statistically significant: logit, P.A., and random effects. In logit estimation, it is observed that the increase of 0.1 unit of positive reciprocity in relationships with stakeholders increases by $3,132 \%$ the probability of the organization presenting open innovation instead of closed innovation. In turn, in the estimation by P.A., the increase of 0.1 unit of positive reciprocity in relationships with stakeholders increases the likelihood of the organization presenting open innovation by $29,209 \%$. Finally, in the estimation by random effects, the increase of 0.1 unit of positive reciprocity in relationships with stakeholders increases $485,320 \%$ the probability of the organization presenting open innovation instead of closed innovation. In none of these estimations did the size control variable prove to be statistically significant.

In the first year, the model estimated by random effects showed better adequacy to the data, presenting a greater log-likelihood. By analyzing the rho (intraclass correlation) in greater detail, it can be said that $46.8 \%$ of the variation that occurs between the data is due to the difference between panels. Therefore, the random effects of reciprocity compose approximately $46.8 \%$ of the total variance of the residues, showing that open innovation is correlated with the stakeholders' relationships based on positive reciprocity of the organizations.

Table 10 - Measures of intra-class manifest association in random-effects logistic

Source: Research data.

\begin{tabular}{lccc}
\hline \multicolumn{1}{c}{ Measure } & Estimate & \multicolumn{2}{c}{$95 \%$ Conf. Interval } \\
\hline Marginal prob. & 0.40 & 0.36 & 0.45 \\
Joint prob. & 0.24 & 0.15 & 0.37 \\
Odds ratio & 4.09 & 1.39 & 27.66 \\
Pearson's r & 0.33 & 0.08 & 0.68 \\
Yule's Q & 0.61 & 0.16 & 0.93 \\
\hline
\end{tabular}

Table 10 reveals that for an organization whose observed propensity is in the median of the sample, the marginal probability of presenting open innovation in any year of the sample is 0.40 . The joint probability of presenting open innovation in two years is 0.24 . Considering the odds ratio of 4.09, it means that the probability of presenting open innovation in 2017 for an organization that presented open innovation in 2008 is approximately four times greater than the corresponding probability for an organization with the same observed characteristics that did not present open innovation in 2008.

In the model in which the dependent variable was tested with a 5-year time lag, three estimates were considered significant (logit, P.A., and R.E.). In terms of estimation by logit, it is observed that the increase of 0.1 unit of positive reciprocity in stakeholders' relationships 
increases by $137,656 \%$ the probability of the organization presenting open innovation in relation to closed innovation. In this estimation, the size control variable showed a statistically significant value, demonstrating that the increase of 1 unit of the size proxy decreases by $37 \%$ the probability of the organization presenting open innovation. In the case of P.A. estimation, it is observed that the increase of 0.1 unit of positive reciprocity in stakeholders' relationships increases by $122,089 \%$ the probability of the organization presenting open innovation instead of closed innovation. The size control variable was also proved to be statistically significant, demonstrating that the increase of 1 unit of the size proxy decreases by about $46 \%$ the probability of the organization presenting open innovation. In the model estimated by random effects, it is noted that the increase of 0.1 unit of positive reciprocity in the relationships with stakeholders increases the likelihood of the organization to present open innovation by $1,373,095 \%$.

In the estimations for the period with a lag of 5 years, the model estimated by random effects showed better adequacy to the data, presenting greater log-likelihood. Analyzing the rho (intraclass correlation) in greater detail, it can be said that $26.1 \%$ of the variation that occurs between the data is due to the difference between panels. Therefore, the random effects of reciprocity compose approximately $26.1 \%$ of the total variance of the residues, indicating that open innovation is correlated with stakeholders' relationships based on positive reciprocity.

Table 11 - Measures of intra-class manifest association in random-effects logistic (lag 5 years)

\begin{tabular}{lccc}
\hline \multicolumn{1}{c}{ Measure } & Estimate & \multicolumn{2}{c}{$95 \%$ Conf. Interval } \\
\hline Marginal prob. & 0.37 & 0.35 & 0.46 \\
Joint prob. & 0.18 & 0.12 & 0.40 \\
Odds ratio & 2.20 & 1.03 & 50.72 \\
Pearson's r & 0.19 & 0.01 & 0.75 \\
Yule's Q & 0.37 & 0.17 & 0.96 \\
\hline
\end{tabular}

Source: Research data.

Table 11 demonstrates that for an organization whose observed propensity is in the sample's median, the marginal probability of presenting open innovation in any year of the sample is 0.37 . The joint probability of presenting open innovation in two years is 0.18 . Considering the odds ratio of 2.20, it means that the probability of presenting open innovation in 2017 for an organization that presented open innovation in 2008 is approximately twice as high as the corresponding probability for an organization with the same characteristics observed that did not present open innovation in 2008. All of this considering that the positive reciprocity was distributed to the stakeholders five years before. 
It is possible to infer that positive reciprocity in relationships with stakeholders has a prolonged and lasting influence on the organization, remaining relevant to innovation even after five years. The most prolonged period revealed to have the most substantial influence of positive reciprocity, with higher probabilities of generating open innovation. It is also noted the strong power that this phenomenon has under the differentiation between closed and open innovation, exerting a strong influence on open innovation.

\subsubsection{Estimation of hypothesis 2}

To estimate hypothesis 2, the logit, population-averaged (P.A.), random effects and fixed effects models were performed. As exhibited in Table 12, two models showed statistical significance.

Table 12 - Estimations of hypothesis 2 in the longitudinal logistic model

\begin{tabular}{|c|c|c|}
\hline \multirow{2}{*}{ Variable } & \multicolumn{2}{|c|}{ Year 5} \\
\hline & Logit & P.A. \\
\hline Stakeholders' relationships based on justice & $\begin{array}{l}6.48^{* *} \\
(2.52)\end{array}$ & $\begin{array}{c}6.88 * * * \\
(2.52)\end{array}$ \\
\hline Size & $\begin{array}{l}-0.36 \\
(0.25)\end{array}$ & $\begin{array}{c}-0.52^{*} \\
(0.28)\end{array}$ \\
\hline Constant & $\begin{array}{c}1.91 \\
(4.28) \\
\end{array}$ & $\begin{array}{c}4.24 \\
(4.41) \\
\end{array}$ \\
\hline Log-likelihood & -27.44 & \\
\hline N. obs. & 47 & 47 \\
\hline N. groups & 25 & 25 \\
\hline Prob. $>$ chi $^{2}$ & 0.014 & 0.009 \\
\hline Pseudo- $\mathrm{R}^{2}$ & $15.1 \%$ & \\
\hline
\end{tabular}

Source: Research data.

With closed innovation as a reference category, it can be noted that stakeholders' relationships based on justice are statistically relevant in the period with a 5-year lag. In terms of logit estimation, parameter 6.48 of the variable relationships based on justice indicates that an increase of 0.1 unit of justice in relationships with stakeholders, on average, makes $6,510 \%$ greater the chance of presenting open innovation instead of closed innovation. Given the differentiation between these two types of innovation, it is possible to infer that relationships with stakeholders based on justice present themselves as a relevant factor for the presence of open innovation, with strong long-term influence.

As for the estimation by P.A., the parameter 6.88 of the variable relationships based on justice suggests that the increase of 0.1 unit of justice in relationships with stakeholders, on 
average, makes $9,716 \%$ greater the chance of the same organization presenting open innovation instead of closed innovation. Such estimation also indicated that the size control variable was significant at $5 \%$, demonstrating that the increase of 1 unit of the size proxy, on average, makes $40.5 \%$ less likely that the same organization will present open innovation instead of closed innovation. Therefore, given the distinction between closed and open innovation, it is possible to infer that relationships with stakeholders based on justice present themselves as a relevant factor for the presence of open innovation, with strong long-term influence.

By analyzing the relationships with stakeholders based on the different types of justice, in periods without time lag and with a 3-year lag, no model was considered statistically significant at the 5\% level. Regarding the 5-year lag models, stakeholders' relationships based on distributive justice and based on interactional justice were considered statistically significant, as shown in Tables 13 and 14.

Table 13 - Estimations of hypothesis $2 \mathrm{a}$ in the longitudinal logistic model

\begin{tabular}{|c|c|c|}
\hline \multirow{2}{*}{ Variable } & \multicolumn{2}{|c|}{ Year 5} \\
\hline & Logit & P.A. \\
\hline Stakeholders' relationships based on distributive justice & $\begin{array}{l}3.53 * \\
(2.03)\end{array}$ & $\begin{array}{l}3.36^{*} \\
(1.96)\end{array}$ \\
\hline Size & $\begin{array}{l}-0.33 \\
(0.21)\end{array}$ & $\begin{array}{c}-0.46^{* *} \\
(0.23)\end{array}$ \\
\hline Constant & $\begin{array}{c}3.23 \\
(3.69) \\
\end{array}$ & $\begin{array}{c}5.30 \\
(3.79) \\
\end{array}$ \\
\hline Log-likelihood & -29.35 & \\
\hline N. obs. & 47 & 47 \\
\hline N. groups & 25 & 25 \\
\hline Prob. $>$ chi $^{2}$ & 0.070 & 0.048 \\
\hline Pseudo- $\mathrm{R}^{2}$ & $9.2 \%$ & \\
\hline
\end{tabular}

$* \mathrm{p}<0.1 \% ; * * \mathrm{p}<0 . \overline{05 ; * * * \mathrm{p}<0.01}$

Source: Research data.

For the estimation of hypothesis $2 \mathrm{a}$, the logit and population-averaged (P.A.) models exhibited statistical significance, as shown in Table 13. In terms of logit estimation, parameter 3.53 of the variable relationships based on distributive justice implies that an increase of 0.1 unit of distributive justice in relationships with stakeholders, on average, makes $331.2 \%$ more likely to present open innovation instead of closed innovation. Given the differentiation between closed innovation and open innovation, from these results, it is possible to infer that the stakeholders' relationships based on distributive justice present themselves as a relevant factor for the presence of open innovation.

In the case of P.A. estimation, parameter 3.36 of the variable relationships based on distributive justice demonstrates that an increase of 0,1 unit of distributive justice in relationships with stakeholders, on average, makes $277.9 \%$ more likely to present open 
innovation instead of closed innovation. Such estimation also exhibited the size control variable as significant at a $5 \%$ level, demonstrating that the increase of 1 unit of the size proxy, on average, makes $36.9 \%$ less likely that the same organization will present open innovation instead of closed innovation. Because of the differentiation between these two types of innovation, it is possible to infer that stakeholders' relationships based on distributive justice present themselves as a relevant factor for the presence of open innovation in the long term.

Table 14 - Estimations of hypothesis $2 \mathrm{~b}$ in the longitudinal logistic model

\begin{tabular}{|c|c|c|}
\hline \multirow{2}{*}{ Variable } & \multicolumn{2}{|c|}{ Year 5} \\
\hline & Logit & P.A. \\
\hline Stakeholders' relationships based on interactional justice & $\begin{array}{c}3.94 * * * \\
(1.40)\end{array}$ & $\begin{array}{c}4.61^{* * *} \\
(1.39)\end{array}$ \\
\hline Size & $\begin{array}{l}-0.30 \\
(0.27)\end{array}$ & $\begin{array}{l}-0.49 \\
(0.32)\end{array}$ \\
\hline Constant & $\begin{array}{c}2.28 \\
(4.52) \\
\end{array}$ & $\begin{array}{c}4.71 \\
(5.01) \\
\end{array}$ \\
\hline Log-likelihood & -26.96 & \\
\hline N. obs. & 47 & 47 \\
\hline N. groups & 25 & 25 \\
\hline Prob. $>$ chi $^{2}$ & 0.011 & 0.003 \\
\hline Pseudo-R ${ }^{2}$ & $16.6 \%$ & \\
\hline
\end{tabular}

${ }^{*} \mathrm{p}<0.1 \% ; * * \mathrm{p}<0.05 ; * * * \mathrm{p}<0.01$

Source: Research data.

For the estimation of hypothesis $2 \mathrm{~b}$, the logit and population-averaged (P.A.) models presented statistical significance, as exhibited in Table 14. In terms of the estimation by logit, parameter 3.94 of the variable stakeholders' relationships based on interactional justice implies that the increase of 0.1 unit of interactional justice in relationships with the stakeholders, on average, makes $504 \%$ greater the chance of presenting open innovation rather than closed innovation.

Regarding P.A. estimation, parameter 4.61 of the variable stakeholders' relationships based on interactional justice indicates that the increase of 0.1 unit of interactional justice in relationships with the stakeholders, on average, makes $994.8 \%$ greater the chance of presenting open innovation rather than closed innovation. Considering the distinction between open innovation and closed innovation, logit and P.A. models demonstrate that it is possible to infer that stakeholders' relationships based on interactional justice present themselves as a relevant factor for the presence of open innovation in the long term. 


\subsubsection{Estimation of hypothesis 3}

Stakeholders' relationships based on the temporal consistency of positive reciprocity are statistically relevant, as exhibited in Table 15.

Table 15 - Estimations of hypothesis $3 \mathrm{a}$ in the longitudinal logistic model

\begin{tabular}{ccc}
\hline \multirow{2}{*}{ Variable } & \multicolumn{2}{c}{ Year 0 } \\
\cline { 2 - 3 } & Logit & P.A. \\
\hline Stakeholders' relationships based on temporal consistency of positive reciprocity & $8.09^{* *}$ & $7.57^{* *}$ \\
& $(3.71)$ & $(3.34)$ \\
Size & 0,27 & 0.21 \\
& $(0.22)$ & $(0.23)$ \\
Constant & -4.69 & -3.86 \\
& $(3.65)$ & $(3.89)$ \\
\hline Log-likelihood & -33.11 & \\
N. obs. & 52 & 52 \\
N. groups & 25 & 25 \\
Prob. $>$ chi $^{2}$ & 0.059 & 0.073 \\
Pseudo-R & $7.7 \%$ & \\
\hline
\end{tabular}

${ }^{*} \mathrm{p}<0.1 \% ; * * \mathrm{p}<0.05 ; * * * \mathrm{p}<0.01$

Source: Research data.

In terms of the estimates that have relationships based on temporal consistency of positive reciprocity as an independent variable, it is observed that such a variable is statistically relevant only for the period without time lag.

Among the estimates for the period without time lag, those estimated by logit and P.A. were considered statistically significant. In terms of the estimation by logit, the 0.1 unit increase in temporal consistency of positive reciprocity in relationships with stakeholders, on average, increases in $32,607 \%$ the probability of the organization presenting open innovation instead of closed innovation. In turn, in terms of P.A. estimation, the 0.1 unit increase in temporal consistency of positive reciprocity in relationships with stakeholders, on average, increases in $19,381 \%$ the probability of the organization presenting open innovation rather than closed innovation.

Hypothesis 3b was also tested, analyzing the relationship between stakeholders' relationships based on temporal consistency of justice and open innovation. However, none of the models tested with this independent variable were significant at $5 \%$ level of significance. It can be inferred, therefore, that relationships with stakeholders based on the temporal consistency of justice do not present themselves as a relevant factor in the differentiation between closed innovation and open innovation, not influencing the latter. 


\subsubsection{Longitudinal multinomial logistic model}

In this multivariate analysis, the dependent variable presented three categories: null innovation (category represented by the number 0); presents closed innovation (category represented by number 1); presents open innovation (category represented by number 2). Models were estimated for three different periods: (i) model without time lag - Year 0; (ii) model in which the dependent variable has a 3-year time lag - Year 3; (iii) model in which the dependent variable shows a 5-year time lag - Year 5.

\subsubsection{Estimation of hypothesis 1}

To estimate hypothesis 1, pooled, random effects (R.E.) and fixed effects (F.E.) models were estimated. Table 16 presents the models that showed statistical significance.

Table 16 - Estimations of hypothesis 1 in the longitudinal multinomial logistic model

\begin{tabular}{|c|c|c|c|c|c|c|c|}
\hline \multirow{2}{*}{\multicolumn{2}{|c|}{ Variable }} & \multicolumn{2}{|c|}{ Year 0} & \multicolumn{2}{|c|}{ Year 3} & \multicolumn{2}{|c|}{ Year 5} \\
\hline & & Pooled & R.E. & Pooled & R.E. & Pooled & R.E. \\
\hline 0 & \multicolumn{7}{|c|}{ (base outcome) } \\
\hline & $\begin{array}{l}\text { Stakeholders' relationships } \\
\text { based on positive reciprocity }\end{array}$ & $\begin{array}{l}-0.60 \\
(1.04)\end{array}$ & $\begin{array}{l}-1.61 \\
(1.63)\end{array}$ & $\begin{array}{c}0.47 \\
(1.13)\end{array}$ & $\begin{array}{c}0.75 \\
(1.58)\end{array}$ & $\begin{array}{c}-2.17^{* *} \\
(1.08)\end{array}$ & $\begin{array}{c}- \\
3.27^{* *} \\
(1.51)\end{array}$ \\
\hline 1 & Size & $\begin{array}{c}0.26^{* * *} \\
(0.09)\end{array}$ & $\begin{array}{c}0.67^{* * *} \\
(0.23)\end{array}$ & $\begin{array}{c}0.23^{* *} \\
(0.09)\end{array}$ & $\begin{array}{l}0.31^{*} \\
(0.17)\end{array}$ & $\begin{array}{l}0.26 * * \\
(0.11)\end{array}$ & $\begin{array}{c}0.31 \\
(0.18)\end{array}$ \\
\hline & Constant & $\begin{array}{l}-6.94 * * * \\
(1.58)\end{array}$ & $\begin{array}{c}- \\
14.71 * * * \\
(4.04)\end{array}$ & $\begin{array}{c}- \\
7.01^{* * *} \\
(1.58)\end{array}$ & $\begin{array}{l}-9.72 * * * \\
(2.89)\end{array}$ & $\begin{array}{c}- \\
6.27^{* * *} \\
(1.80)\end{array}$ & $\begin{array}{c}- \\
7.62^{* *} \\
(3.02)\end{array}$ \\
\hline & $\begin{array}{l}\text { Stakeholders' relationships } \\
\text { based on positive reciprocity }\end{array}$ & $\begin{array}{l}2.87^{*} \\
(1.55)\end{array}$ & $\begin{array}{l}6.55^{*} \\
(3.36)\end{array}$ & $\begin{array}{l}3.73^{* *} \\
(1.63)\end{array}$ & $\begin{array}{l}6.70^{* *} \\
(2.78)\end{array}$ & $\begin{array}{l}2.78^{*} \\
(1.68)\end{array}$ & $\begin{array}{c}2.46 \\
(2.07)\end{array}$ \\
\hline 2 & Size & $\begin{array}{c}0.34 * * * \\
(0.10)\end{array}$ & $\begin{array}{l}0.81 * * \\
(0.30)\end{array}$ & $\begin{array}{l}0.20^{* *} \\
(0.10)\end{array}$ & $\begin{array}{c}0.28 \\
(0.22)\end{array}$ & $\begin{array}{c}0.02 \\
(0.11)\end{array}$ & $\begin{array}{c}0.01 \\
(0.19)\end{array}$ \\
\hline & Constant & $\begin{array}{c}- \\
10.79^{* * *} \\
(1.75) \\
\end{array}$ & $\begin{array}{c}- \\
24.27 * * * \\
(5.99)\end{array}$ & $\begin{array}{c}- \\
8.93^{* * *} \\
(1.80)\end{array}$ & $\begin{array}{c}- \\
14.36^{* * *} \\
(4.15)\end{array}$ & $\begin{array}{c}- \\
5.60^{* * * *} \\
(2.05)\end{array}$ & $\begin{array}{c}- \\
6.46^{* *} \\
(3.19)\end{array}$ \\
\hline & $\operatorname{Var}(\alpha c i)$ & & $\begin{array}{r}6.49 \\
(3.23) \\
\end{array}$ & & $\begin{array}{c}3.56 \\
(1.70) \\
\end{array}$ & & $\begin{array}{c}3.25 \\
(1.86)\end{array}$ \\
\hline & $\operatorname{Var}(\alpha \mathrm{oi})$ & & $\begin{array}{l}12.51 \\
(6.52) \\
\end{array}$ & & $\begin{array}{c}6.11 \\
(3.09) \\
\end{array}$ & & $\begin{array}{c}3.37 \\
(1.99) \\
\end{array}$ \\
\hline & $\operatorname{Cov}(\alpha \operatorname{ci}, \alpha \mathrm{oi})$ & & $\begin{array}{l}8.44 * * \\
(4.17)\end{array}$ & & $\begin{array}{l}4.14^{* *} \\
(1.88) \\
\end{array}$ & & $\begin{array}{l}3.22 * * \\
(1.60)\end{array}$ \\
\hline & Log-likelihood & -236.30 & -188.93 & -234.57 & -205.57 & -199.34 & $-\overline{1}$ \\
\hline & $\begin{array}{l}\text { N. obs. } \\
\text { N. groups }\end{array}$ & 710 & 710 & 710 & 710 & 710 & 710 \\
\hline & Prob. $>$ chi $^{2}$ & 0.000 & & 0.001 & & 0.017 & \\
\hline & Pseudo-R ${ }^{2}$ & $5.44 \%$ & & $3.76 \%$ & & $2.92 \%$ & \\
\hline
\end{tabular}

$* \mathrm{p}<0.1 \% ; * * \mathrm{p}<0.05 ; * * * \mathrm{p}<0.01$

Source: Research data. 
Considering null innovation as a reference category, it can be noted that stakeholders' relationships based on positive reciprocity are statistically relevant for open innovation in all periods analyzed. Therefore, the presence of positive reciprocity in stakeholders' relationships proves to be a perennial factor of differentiation between the null innovation and the presence of open innovation.

In all models tested, two estimates were considered significant, pooled and random effects, with the latter model showing a higher log-likelihood value. In the model where the dependent variable was tested without a temporal lag, in terms of pooled estimation, it is observed that the increase of 0.1 unit of positive reciprocity in relationships with stakeholders increases by $166 \%$ the probability of the organization presenting open innovation in relation to not presenting innovation. The size was also shown to be statistically significant, demonstrating that the increase of 1 unit in the natural logarithm of total assets increases the probability of the organization to present open innovation by $40.5 \%$.

Random effects estimation shows that a 0.1 increase in positive reciprocity in relationships with stakeholders increases the probability of the organization presenting open innovation by $6,982 \%$ compared to it not presenting innovation. In turn, in terms of the size control variable, the 0.81 parameter demonstrates that an increase of 1 unit in the natural logarithm of total assets increases the likelihood of open innovation by $124.8 \%$.

In models where the dependent variable was tested with a 3-year time lag, the pooled estimation demonstrates that a 0.1 increase in positive reciprocity in stakeholders' relationships increases the likelihood of open innovation in the organization by $407 \%$ in relation to it not presenting innovation. The size was also proved to be statistically significant, demonstrating that the increase of 1 unit in the natural logarithm of total assets increases the probability of the organization presenting open innovation by $22 \%$.

Random effects estimation demonstrates that a 0.1 increase in positive reciprocity in stakeholders' relationships increases the likelihood of open innovation in the organization by $8,114 \%$, in relation to it not presenting innovation.

In the estimates in which the dependent variable was tested with a 5-year temporal lag, two estimates were considered statistically significant: pooled and random effects. In the pooled effects estimation, it is noted that a 0.1 increase in positive reciprocity in relationships with stakeholders increases the probability of open innovation by $151 \%$ in relation to not presenting innovation. In terms of the random effects estimation, the independent variable was not statistically significant for open innovation and only for closed innovation compared to null innovation. 


\subsubsection{Estimation of hypothesis 2}

To estimate hypothesis 2, the pooled, random effects, and fixed effects models were predicted. Table 17 exhibits the models that presented statistical significance.

Table 17 - Estimations of hypothesis 2 in the longitudinal multinomial logistic model

\begin{tabular}{|c|c|c|c|}
\hline & \multirow{2}{*}{ Variable } & \multicolumn{2}{|c|}{ Year 5} \\
\hline & & Pooled & R.E. \\
\hline \multicolumn{4}{|c|}{0} \\
\hline & Stakeholders' relationships based on justice & $\begin{array}{c}-0.59 \\
(1.00)\end{array}$ & $\begin{array}{c}0.05 \\
(1.44)\end{array}$ \\
\hline 1 & Size & $\begin{array}{l}0.22 * * \\
(0.10)\end{array}$ & $\begin{array}{c}0.26 \\
(0.17)\end{array}$ \\
\hline & Constant & $\begin{array}{c}-6.64 * * * \\
(1.78)\end{array}$ & $\begin{array}{c}-8.71 * * \\
(3.14)\end{array}$ \\
\hline \multirow{10}{*}{2} & Stakeholders' relationships based on justice & $\begin{array}{l}3.12^{* *} \\
(1.44)\end{array}$ & $\begin{array}{l}4.89^{* *} \\
(2.09)\end{array}$ \\
\hline & Size & $\begin{array}{c}0.05 \\
(0.21)\end{array}$ & $\begin{array}{c}0.05 \\
(0.20)\end{array}$ \\
\hline & Constant & $\begin{array}{c}-6.24 * * * \\
(2.08)\end{array}$ & $\begin{array}{c}-8.58 * * \\
(3.60)\end{array}$ \\
\hline & $\operatorname{Var}(\alpha \mathrm{ci})$ & & $\begin{array}{c}3.14 \\
(1.83) \\
\end{array}$ \\
\hline & $\operatorname{Var}(\alpha \mathrm{oi})$ & & $\begin{array}{c}4.01 \\
(2.34) \\
\end{array}$ \\
\hline & $\operatorname{Cov}(\alpha \operatorname{ci}, \alpha o i)$ & & $\begin{array}{c}3.30 \\
(1.68)\end{array}$ \\
\hline & Log-likelihood & -199.99 & -185.85 \\
\hline & $\begin{array}{l}\text { N. obs. } \\
\text { N. groups }\end{array}$ & 710 & 710 \\
\hline & Prob. $>$ chi $^{2}$ & 0.030 & \\
\hline & Pseudo-R ${ }^{2}$ & $2.60 \%$ & \\
\hline
\end{tabular}

$* \mathrm{p}<0.1 \% ; * * \mathrm{p}<0.05 ; * * * \mathrm{p}<0.01$

Source: Research data.

Considering null innovation as a reference category, it can be noted that stakeholders' relationships based on justice are statistically relevant for open innovation only in the 5-year lag tests. Therefore, the presence of justice/fairness in stakeholders' relationships proves to be a differentiating factor between the absence of innovation and the presence of open innovation for long-term innovations.

Regarding the 5-year temporal lag tests, the pooled and random effects estimates were also considered statistically significant. Regarding the pooled effects estimation, it is observed that a 0.1 increase of justice in relationships with stakeholders increases the probability of the organization presenting open innovation by $216.5 \%$ compared to it not presenting innovation. In terms of the random effects estimation, it can be noted that a 0.1 increase of justice in 
stakeholders' relationship increases the probability of the organization presenting open innovation by $1,319.5 \%$ compared to null innovation.

In terms of stakeholders' relationships based on the different types of justice, none of the estimated models without a temporal lag and with a 3-year time lag proved to be statistically significant. As for the models with a 5-year lag, stakeholders' relationships based on interactional justice proved to be relevant at the 5\% level, as presented in Table 18 .

Table 18 - Estimations of hypothesis $2 \mathrm{~b}$ in the longitudinal multinomial logistic model

\begin{tabular}{|c|c|c|c|}
\hline \multirow{2}{*}{\multicolumn{2}{|c|}{ Variable }} & \multicolumn{2}{|c|}{ Year 5} \\
\hline & & \multirow[t]{2}{*}{ Pooled } & \multirow[t]{2}{*}{ R.E. } \\
\hline 0 & (base outcome) & & \\
\hline \multirow{3}{*}{1} & Stakeholders' relationships based on interactional justice & $\begin{array}{c}-0.82 \\
(0.69)\end{array}$ & $\begin{array}{l}-0.40 \\
(0.93)\end{array}$ \\
\hline & Size & $\begin{array}{c}0.24 * * \\
(0.10)\end{array}$ & $\begin{array}{c}0.26 \\
(0.17)\end{array}$ \\
\hline & Constant & $\begin{array}{c}-6.76^{* * *} * \\
(1.74) \\
\end{array}$ & $\begin{array}{c}-8.71 * * \\
(3.14) \\
\end{array}$ \\
\hline \multirow{10}{*}{2} & Stakeholders' relationships based on interactional justice & $\begin{array}{l}2.01 * * \\
(0.87)\end{array}$ & $\begin{array}{l}3.42 * * \\
(1.43)\end{array}$ \\
\hline & Size & $\begin{array}{c}0.02 \\
(0.12)\end{array}$ & $\begin{array}{l}-0.001 \\
(0.21)\end{array}$ \\
\hline & Constant & $\begin{array}{c}-5.10 * * * \\
(1.94)\end{array}$ & $\begin{array}{c}-7.32 * * \\
(3.60)\end{array}$ \\
\hline & $\operatorname{Var}(\alpha c i)$ & & $\begin{array}{c}2.94 \\
(1.71)\end{array}$ \\
\hline & $\operatorname{Var}(\alpha \mathrm{oi})$ & & $\begin{array}{c}4.61 \\
(2.74)\end{array}$ \\
\hline & $\operatorname{Cov}(\alpha \operatorname{ci}, \alpha o i)$ & & $\begin{array}{l}3.25^{*} \\
(1.69)\end{array}$ \\
\hline & Log-likelihood & -199.10 & -184.74 \\
\hline & $\begin{array}{l}\text { N. obs. } \\
\text { N. groups }\end{array}$ & 710 & 710 \\
\hline & Prob. $>$ chi $^{2}$ & 0.014 & \\
\hline & Pseudo- $\mathrm{R}^{2}$ & $3.03 \%$ & \\
\hline
\end{tabular}

$* \mathrm{p}<0.1 \% ; * \mathrm{*}<0.05 ; * * * \mathrm{p}<0.01$

Source: Research data.

Regarding the 5-year temporal lag tests, the pooled and random effects estimates were also considered statistically significant. Concerning pooled estimation, it is observed that the increase of 0.1 unit of interactional justice in relationships with stakeholders increases by $64.6 \%$ the probability of the organization presenting open innovation in relation to null innovation. In terms of estimation by random effects, it can be noted that the increase of 0.1 unit of interactional justice in relationships with stakeholders increases by $295.7 \%$ the likelihood of the organization presenting open innovation in relation to not presenting innovation. 


\subsubsection{Estimation of hypothesis 3}

Hypothesis 3 was tested using three different estimates for the analysis periods, obtaining as statistically relevant the estimates of the period without a temporal lag, as shown in Table 19.

Table 19 - Estimations of hypothesis $3 \mathrm{a}$ in the longitudinal multinomial logistic model

\begin{tabular}{|c|c|c|c|}
\hline & \multirow{2}{*}{ Variable } & \multicolumn{2}{|c|}{ Year 0} \\
\hline & & Pooled & R.E. \\
\hline 0 & \multicolumn{3}{|l|}{ (base outcome) } \\
\hline \multirow{3}{*}{1} & Stakeholders' relationships based on temporal consistency of positive reciprocity & $\begin{array}{c}-3.63^{* *} \\
(1.44)\end{array}$ & $\begin{array}{c}-5.63 * * * \\
(2.12)\end{array}$ \\
\hline & Size & $\begin{array}{c}0.20^{* *} \\
(0.10)\end{array}$ & $\begin{array}{c}0.45^{* *} \\
(0.21)\end{array}$ \\
\hline & Constant & $\begin{array}{c}-6.22 * * * \\
(1.69) \\
\end{array}$ & $\begin{array}{c}-11.81 * * * \\
(3.68)\end{array}$ \\
\hline \multirow{11}{*}{2} & Stakeholders' relationships based on temporal consistency of positive reciprocity & $\begin{array}{c}-0.92 \\
(1.79)\end{array}$ & $\begin{array}{l}-0.71 \\
(2.97)\end{array}$ \\
\hline & Size & $\begin{array}{c}0.32 * * * \\
(0.10)\end{array}$ & $\begin{array}{c}0.71 * * \\
(0.28)\end{array}$ \\
\hline & Constant & $\begin{array}{c}-8.48 * * * \\
(1.78) \\
\end{array}$ & $\begin{array}{c}-17.21 * * * \\
(5.11)\end{array}$ \\
\hline & $\operatorname{Var}(\alpha \mathrm{ci})$ & & $\begin{array}{c}4.41 \\
(2.30)\end{array}$ \\
\hline & $\operatorname{Var}(\alpha \mathrm{oi})$ & & $\begin{array}{c}7.83 \\
(4.17) \\
\end{array}$ \\
\hline & $\operatorname{Cov}(\alpha c i, \alpha o i)$ & & $\begin{array}{l}5.10^{*} \\
(2.64)\end{array}$ \\
\hline & Log-likelihood & -201.90 & -170.81 \\
\hline & N. obs. & 586 & 586 \\
\hline & N. groups & & \\
\hline & Prob. $>$ chi $^{2}$ & 0.001 & \\
\hline & Pseudo-R ${ }^{2}$ & $4.52 \%$ & \\
\hline
\end{tabular}

${ }^{*} \mathrm{p}<0.1 \% ; * * \mathrm{p}<0.05 ; * * * \mathrm{p}<0.01$

Source: Research data.

Considering null innovation as a reference category, it can be noted that relationships based on the temporal consistency of positive reciprocity are statistically relevant only in the period without a lag. However, the presence of temporal consistency of positive reciprocity in stakeholders' relationships is a differentiating factor between null innovation and the presence of closed innovation.

In both estimations that are considered statistically valid, it is observed that as the amount of temporal consistency of positive reciprocity in stakeholders' relationships increases, the likelihood of the organization presenting closed innovation decreases. Variations in the temporal consistency of positive reciprocity, therefore, have a negative effect on innovation generation, specifically on closed innovation generation. 
Estimations were also performed to test the influence of the temporal consistency of justice. However, none of the models tested for different periods showed statistical significance.

\subsection{Summary of Results}

Illustration 13 exhibits a summary of the results of this research in comparison with its objectives and hypotheses.

\begin{tabular}{|c|c|c|}
\hline Objective & Hypothesis & Result \\
\hline $\begin{array}{l}\text { Analyze the relationship between } \\
\text { stakeholders' relationships based on } \\
\text { positive reciprocity and open innovation }\end{array}$ & $\begin{array}{c}\mathrm{H}_{1} \text { : Stakeholders' relationships based on positive } \\
\text { reciprocity are positively related to the } \\
\text { development of open innovation }\end{array}$ & Confirmed \\
\hline \multirow{4}{*}{$\begin{array}{l}\text { Analyze the relationship between } \\
\text { stakeholders' relationships based on } \\
\text { justice and open innovation }\end{array}$} & $\begin{array}{c}\mathrm{H}_{2} \text { : Stakeholders' relationships based on justice } \\
\text { are positively related to the development of open } \\
\text { innovation }\end{array}$ & Confirmed \\
\hline & $\begin{array}{l}\mathrm{H}_{2 \mathrm{a}} \text { : Stakeholders' relationships based on } \\
\text { distributive justice are positively related to the } \\
\text { development of open innovation }\end{array}$ & Confirmed \\
\hline & $\begin{array}{l}\mathrm{H}_{2 b} \text { : Stakeholders' relationships based on } \\
\text { interactional justice are positively related to the } \\
\text { development of open innovation }\end{array}$ & Confirmed \\
\hline & $\begin{array}{l}\mathrm{H}_{2 \mathrm{c}} \text { : Stakeholders' relationships based on } \\
\text { procedural justice are positively related to the } \\
\text { development of open innovation }\end{array}$ & Refuted \\
\hline \multirow{3}{*}{$\begin{array}{l}\text { Analyze the relationship between } \\
\text { stakeholders' relationships based on } \\
\text { temporal consistency and open } \\
\text { innovation }\end{array}$} & $\begin{array}{c}\mathrm{H}_{3} \text { : Stakeholders' relationships based on temporal } \\
\text { consistency are positively related to the } \\
\text { development of open innovation }\end{array}$ & $\begin{array}{l}\text { Partially } \\
\text { confirmed }\end{array}$ \\
\hline & $\begin{array}{l}\mathrm{H}_{3 \mathrm{a}} \text { : Stakeholders' relationships based on temporal } \\
\text { consistency of positive reciprocity are positively } \\
\text { related to the development of open innovation }\end{array}$ & Confirmed \\
\hline & $\begin{array}{l}\mathrm{H}_{3 b} \text { : Stakeholders' relationships based on } \\
\text { temporal consistency of justice are positively } \\
\text { related to the development of open innovation }\end{array}$ & Refuted \\
\hline
\end{tabular}

As shown in Illustration 13, most of the study's hypotheses were confirmed by statistical analysis. It is noteworthy that these results are restricted to the sample analyzed, making it impossible to generalize. 


\section{DISCUSSION}

The discussion of the results involves the resumption of the research question, the objectives, and hypotheses of the study. The variables and their respective indicators are also evaluated in order to present the contributions of this study, emerging from the relationships demonstrated in the conceptual model. Thus, the research problem identified in theory is presented through the following question: What is the relationship between the different types of stakeholders' relationships and open innovation? In response to this issue, initially, three specific objectives were established, precisely, (i) analyze the relationship between stakeholders' relationships based on positive reciprocity and open innovation; (ii) analyze the relationship between stakeholders' relationships based on justice and open innovation; and (iii) analyze the relationship between stakeholders' relationships based on temporal consistency and open innovation.

According to the results obtained in the data analysis, it was found that, in isolation, two of the three proposed stakeholders' relationships types have a positive and statistically significant relationship with the presence of open innovation, as shown in Tables 9, 12, 16 and 17.

Stakeholders' relationships based on positive reciprocity refer to the first hypothesis of the study $\left(\mathrm{H}_{1}\right)$ : Stakeholders' relationships based on positive reciprocity are positively related to the development of open innovation. This hypothesis was confirmed, showing that, in the companies studied, relationships with stakeholders based on positive reciprocity, delivering higher reciprocity value, can result in a higher probability of presenting open innovation.

The results are consistent with previous studies demonstrating that reciprocity is a driver for the formation of knowledge ties (Giuliani, 2013; Swärd, 2016; Liu et al., 2018). However, this study provides a deeper understanding of how stakeholders' relationships, by focusing on delivering positive reciprocity, contribute to the better collective performance of the organization by generating open innovation.

Recognition and understanding of the unique, additive, and interactional effects of stakeholders' relationships, taking a more in-depth and more detailed look at such relationships and their stakeholders, is enabled through the analysis of microfoundations (Barney \& Felin, 2013; Bridoux \& Stoelhorst, 2014; Felin, Foss, \& Ployhart, 2015). It is recognized that individuals, involved in multiple intra-organizational and inter-organizational interactions, feel motivated to contribute and collaborate positively when they receive positive reciprocity 
actions from the organization (Axelrod, 2006; Hoppner \& Griffith, 2011; Huang \& Li, 2017; Pervan, Bove, \& Johnson, 2009), a fact that is proven by the present research.

Therefore, the dynamics and complexity of these relationships, marked by the movements and behavioral variations of the multiple stakeholders involved in these interactions, are contingent on the way the organization treats them (Bridoux \& Stoelhorst, 2014; Bosse \& Coughlan, 2016; Griffin, 2016). So, by delivering more positive reciprocity to stakeholders in their relationships, the organization receives mutually contingent bonuses such as flexibility, information, and solidarity, among others (Gouldner 1960; Harrison, Bosse \& Phillips, 2010; Hoppner \& Griffith, 2011; Liu et al., 2018).

The results demonstrate the centrality and importance of positive reciprocity in relationships with stakeholders, a relevant factor for the generation of open innovation instead of closed innovation, as well as for the generation of open innovation compared to null innovation. It is observed that the influence of stakeholders' relationships based on positive reciprocity is even stronger in the differentiation between open innovation and closed innovation. So, it can be inferred that this type of relationship is essential for the stakeholder to feel willing to collaborate in a closer and more reliable way to the organization.

Literature shows that reciprocity exchanges are not necessarily accomplished through immediate equivalent returns, but also through returns over the length of the relationship, seeking to balance the exchange (Liu et al., 2018). This characteristic is proven in the present research since the results show the immediate exchanges (tests without a time lag), as well as exchanges over more extended periods (tests with a 5-year time lag). As open innovation needs richer and differentiated knowledge and information (Bogers et al., 2017; Chesbrough, 2012; Gould, 2012), the prolonged reciprocal exchange favors the recognition of the actors involved of the goodwill of the other party, giving reliability and stability to relationships and thus favoring collaboration and information sharing (Gouldner, 1960; Hoppner \& Griffith, 2011; Jap \& Anderson, 2007; Liu et al., 2018; Swärd, 2016).

These findings allow it to be emphasized that the immediate and residual/prolonged effect (perceived by the influence of positive reciprocity in years $t+3$ and $t+5$ ) present similar dimensions, leading to the conclusion that the high power of reciprocity does not disperse over time. As evidenced by the literature, in the present study, reciprocity is actually shown to be a continuous process of satisfying mutual expectations in the stakeholder-organization relationship (Levinson, 1965), encouraging the maintenance of relationships in anticipation of future returns (Bignoux, 2006; Swärd, 2016). 
The second hypothesis of the study concerns stakeholders' relationships based on justice $\left(\mathrm{H}_{2}\right)$ : Stakeholders' relationships based on justice are positively related to the development of open innovation. This hypothesis was confirmed in the present empirical research, demonstrating that, among the companies studied, those that have relationships with stakeholders based on justice, delivering greater justice value, can have as a result a higher probability of presenting open innovation.

Results demonstrate that justice in relationships with stakeholders influences the probability of presenting open innovation, both in the estimates that have closed innovation as a reference category, and null innovation. In both cases, justice in relationships with stakeholders influences the probability of presenting open innovation only in the period with a 5-year lag.

Because of its characteristic of being a value judgment of previously taken actions distribution of results, interpersonal treatment, established processes and procedures (Bosse, Phillips, \& Harrison, 2009; Colquitt, 2001; Cropanzano et al., 2001) - it is understandable that the justice variable has no influence on the period without a lag. Time lags allow stakeholders to better evaluate and respond to justice actions in their relationships with the organization.

The findings highlight the need for the 'justice' phenomenon of subsequent periods in the analysis and consequent response to the company's actions. It is also shown that actions that deliver justice in stakeholders' relationships have a longer-term effect, which is pertinent to the literature in terms of a tendency to sustain relationships (Bridoux \& Stoelhorst, 2014).

Aforesaid results enrich the integrative perspective of justice highlighted by Cropanzano et al. (2001), exemplifying the link between justice events (represented here by the organization's actions) and the responses of individuals/stakeholders (illustrated here by innovation typologies). The relevance of the justice variable, calculated by weighing distributive justice, interactional justice, and procedural justice, demonstrates the importance of the integrative view of the 'justice' construct, considering the mutual influence of the perceptions of the three types of justice (Cropanzano et al., 2001; Lind, 2001).

Specifically, distinct statistical models tested demonstrate the importance of different relationships with stakeholders based on the types of justice. The longitudinal logistical model highlights the influence of relationships with stakeholders based on distributive justice and relationships with stakeholders based on interactional justice for the generation of open innovation, confirming hypotheses $\mathrm{H}_{2 \mathrm{a}}$ and $\mathrm{H}_{2}$. In turn, the multinomial longitudinal logistic model highlights the influence of relationships with stakeholders based on interactional justice for the generation of open innovation, confirming the hypothesis $\mathrm{H}_{2 b}$. 
These findings emphasize the relevance of interpersonal elements in the treatment of stakeholders in interactions with the organization (Bies, 2015; Bosse, Phillips, \& Harrison, 2009; Harrison \& Wicks, 2013), elements with more significant presence in the organization when adopting an approach of stakeholder management focused on the specificities of stakeholders, recognizing them as individuals with motivations, emotions, and perceptions (Bridoux \& Stoelhorst, 2016; Bosse \& Coughlan, 2016; McVea \& Freeman, 2005).

More than distinctions in terms of economic results, the findings demonstrate that organizations that develop open innovation are different from those that present null innovation or closed innovation in terms of socio-emotional results, specifically by the way they interact and treat their stakeholders. By having human trust and dignity as central properties (Bies, 2015), interactional justice, by being present in relationships with stakeholders, effectively provides essential elements so that these individuals feel involved and willing to share information and more in-depth knowledge with the organization (Bies, 2015; Cropanzano et al., 2001; Harrison, Bosse \& Phillips, 2010; McVea \& Freeman, 2005).

Especially in cooperative schemes, interactional justice and its outcomes, including trust between those individuals involved, facilitate the effectiveness of the relationship (Bies, 2015; Colquitt et al., 2001). The dignified, respectful, and transparent treatment of stakeholders is essential for the creation and maintenance of collaborative, friendly, and long-lasting relationships (Flammer \& Bansal, 2017; Harrison \& Bosse, 2013; Hayibor, 2017; Tantalo \& Priem, 2016; Wang \& Choi, 2013). These diverse forms of cooperation are fundamental for the generation of open innovation (Fisher \& Qualls, 2018; Randhawa, Wilden, \& Hohberger, 2016; West \& Gallagher, 2006), considering that they are relationships marked by the exchange of resources, critical knowledge, and technologies, with the creation and exploration of new ways to create value between stakeholders and the organization (Barney, 2018; Griffin, 2016).

Focusing on the relationship between open innovation and closed innovation, the relevance of relationships with stakeholders based on distributive justice emerges as a differential. However, this type of relationship with stakeholders did not prove to be statistically significant when considering the presence of open innovation to the detriment of null innovation.

Such results illustrate that in situations in which there is no innovation, it is not enough for the company to invest only in the allocation of distributive justice, more interconnected to economic factors (Leventhal, 1976), for the organization to develop innovation, specifically open innovation. However, in situations where closed innovation already exists, the 
organization's investment in relationships with a fairer distribution of outcomes generates a higher propensity for open innovation.

Considering that closed innovation is focused on the development of in-house innovation, resulting from the interactions of internal stakeholders, collaboration is more limited in this type of innovation, occurring basically through a network of employees (Berchicci, 2013; Chesbrough, 2003; Lee, Olson, \& Trimi, 2012). Aforesaid an approach, therefore, has its perspective of distributive justice focused on internal actors, with relationships with stakeholders producing a smaller range of actions of this type of justice than organizations that develop open innovation, which should be concerned with relationships based on distributive justice with both internal stakeholders and external stakeholders. Therefore, due to the intrinsic characteristics of the types of innovation (Almirall \& Casadesus-Masanell, 2010; Chesbrough, 2003), there is an expectation of relationships with stakeholders based on the most diverse and rich distributive justice when focused on the generation of open innovation.

The relevance of relationships with stakeholders based on distributive justice for open innovation, demonstrated in this research, is in line with the results of other studies, which illustrate the role of distributive justice for partnerships such as joint ventures (Arslan, 2018) and strategic alliances (Luo, 2007). As the organization encourages a more significant presence of distributive justice in relationships with stakeholders, consequently generating higher productivity, harmony, and solidarity (Leventhal, 1976), a more collaborative environment is promoted, with encouragement to communication and less fear of exploration (Luo, 2007). Over time, if there is no fair distribution, the relationship tends to be broken (Arslan, 2018; Luo, 2007).

Regarding relationships with stakeholders based on procedural justice, hypothesis $\mathrm{H}_{2 \mathrm{c}}$ was rejected, since no statistically significant model was found with such a variable. It should be noted that this type of justice has always presented the lowest averages concerning the other types, as shown in Tables 3 and 6, in addition to having the lowest value in 7 years out of the 10 years analyzed, as shown in Table 7.

Such data highlight the scarcity, in the analyzed environment, of actions and events of procedural justice. The sample of Brazilian organizations analyzed, whether composed of companies that present innovation or not, is characterized for similar lack of fair process criteria, maybe for lack of voice during the decision-making process or influence over the outcome (Colquitt et al., 2001; Leventhal, 1980). In this sense, all of them seem to present a similar level of procedural justice in the stakeholders' relationships, not having this typology of justice as a distinctive attribute. The demands of ISE in terms of ethical and moral standards 
in terms of procedures (ISE, 2018b) may create a pattern followed by the majority of organizations, not differentiating them in this term.

The third hypothesis of the study concerns the stakeholders' relationships based on temporal consistency $\left(\mathrm{H}_{3}\right)$ : Stakeholders' relationships based on temporal consistency are positively related to the development of open innovation. This hypothesis was partially confirmed in the research, considering that no statistically significant relationship was found between the temporal consistency of justice and the generation of open innovation. Considering the longitudinal logistic models, stakeholders' relationships based on temporal consistency of positive reciprocity were positively related to open innovation generation in the model with no lag.

Considering the perspective of justice in terms of its evaluation based on the event at the time of justice experience (Cropanzano et al., 2001; Lind, 2001), each event has a unique context and actions, and it is difficult to present a standard behavior for different realities. In this sense, it would be problematic to compare justice experiences occurred in different years. Also, as highlighted by Wang and Choi (2013), it would be interesting to investigate the temporal consistency of justice for each stakeholder separately, as distinct stakeholder groups may construct different relationships with the firm (Bosse \& Coughlan, 2016; Brickson, 2007; Bridoux \& Stoelhorst, 2014; Jones, Harrison, \& Phelps, 2018).

In the longitudinal logistic model tested without time lag, relationships with stakeholders based on the consistency of positive reciprocity proved to be significant for open innovation, having a positive parameter, demonstrating that the higher the value of the variation of positive reciprocity, the greater the chance of presenting open innovation compared to closed innovation. Therefore, in order to have open innovation, it is expected, over the years, that relationships with stakeholders will deliver higher positive reciprocity value, year after year. Considering that, on average, according to Table 7 , such variations of positive reciprocity in relationships with stakeholders were not accentuated, it can be inferred that the rule of temporal consistency was not violated (Leventhal, 1980; Wang \& Choi, 2013).

The results reveal that the pattern established by the analyzed organizations, specifically, in terms of increased delivery of positive reciprocity in relationships with stakeholders compared to the delivery of the previous year, affected stakeholders, causing them to trust and cooperate more with such companies (Brickson, 2007; Chen \& Miller, 2015), resulting in the development of open innovation.

It is also observed, according to Tables 3, 6 and 7, that the annual variations of the relationships with the stakeholders based on the temporal consistency of positive reciprocity 
and of the relationships with the stakeholders based on the temporal consistency of justice present, on average, tiny values that do not reach one-tenth of the maximum value that these relationships can reach. In terms of the temporal consistency of justice, there is not much differentiation between the values of null innovation, closed innovation, and open innovation. However, in terms of the temporal consistency of positive reciprocity, closed innovation stands out negatively, presenting a very different value concerning open innovation and null innovation.

The results also highlight the distinctive amount of requirements and actions needed to develop open innovation, considering the starting point or the reference category. It is observed that when the organization does not have any kind of innovation (null innovation), to develop open innovation, it is necessary to focus actions and efforts, investing on the construction or improvement of a small number of relationships with stakeholders, particularly in stakeholders' relationships based on positive reciprocity, based on justice, and based on interactional justice. So, as exhibited in Tables 16, 17, and 18, it is required for organizations a greater focus on actions of justice/fairness, socio-emotional aspects, followed by positive actions considered as signs of goodwill.

Notwithstanding, in the circumstances in which the organization already has a kind of innovation (closed innovation), to develop open innovation, it is necessary to care about more different actions and more widespread efforts. So, organizations have to invest in the construction or improvement of a diverse number of relationships with stakeholders, particularly in stakeholders' relationships based on positive reciprocity, based on justice, based on distributive justice, based on interactional justice and based on temporal consistency of positive reciprocity. As exhibited in Tables 9, 12, 13, 14, and 15, besides the required focus on actions of justice, socio-emotional aspects, and positive actions considered as signs of goodwill, the organizations have to care more about the allocation of tangible outcomes and with establishing and sustaining a consistent behavior.

Based on the fact that the development of open innovation requires critical resources, exclusive knowledge and collaboration between internal and external stakeholders to the organization (Barney, 2018; Bogers et al., 2018; Flammer \& Bansal, 2017; Harrison, Bosse, \& Phillips, 2010; Kazadi, Lievens, \& Mahr, 2016), the results of the tests performed in this study support the thesis that stakeholders' relationships are positively related to the development of open innovation, influencing it through relationships based on positive reciprocity, based on justice, based on interactional justice, and based on distributive justice, as well as through relationships based on temporal consistency of positive reciprocity. 
Therefore, the main contribution of this study is to provide a model that explains, from a view of the microfoundations of Stakeholder Theory (Bridoux \& Stoelhorst, 2014; Bosse \& Coughlan, 2016; Hall, Bachor, \& Matos, 2014; Jones, Harrison, \& Phelps, 2018), the development of open innovation, highlighting the importance of the different types of relationships developed with stakeholders, thus meeting the call for studies that advance in understanding the role and motivation of the actors involved in this type of innovation (Bogers et al., 2017; Lüttgens et al ., 2014) and understanding the open innovation relationship network as a whole (Flammer \& Kacperczyk, 2016; Randhawa, Wilden, \& Hohberger, 2016; West \& Bogers, 2014). 


\section{CONCLUDING REMARKS}

When discussing the theoretical field of open innovation, little is understood about the functioning, management, and integration of the network of relationships between the organization and the various stakeholders, internal and external, as a whole (Bogers et al., 2017;

Flammer \& Kacperczyk, 2016; Randhawa, Wilden, \& Hohberger, 2016). Little is also understood about the motivations and interrelations of relevant stakeholders to the generation of open innovation (Bogers et al., 2017; Lüttgens et al., 2014). In an effort to begin filling the gaps presented in the problem of this study, this dissertation was concerned with answering the following research question: what is the relationship between the different stakeholders' relationships and open innovation?

In this context, the aim of this research was to explain the relationship between different stakeholders' relationships and open innovation. To achieve this broader objective, it was divided into some specific objectives. Thus, after data collection and subsequent analysis, the relationship between stakeholders' relationships based on positive reciprocity and open innovation, stakeholders' relationships based on justice and open innovation, and stakeholders' relationships based on temporal consistency and open innovation were verified.

In methodological terms, a quantitative approach was adopted, using secondary data collected from the ISE questionnaire and the INPI website. After data collection, descriptive and multivariate statistical analyses were performed. First, to characterize the sample, the frequency and mean of the variables were analyzed, also using Anova One way to verify the statistical difference between the means. Subsequently, for testing the proposed hypotheses, the multivariate techniques of a longitudinal logistic model and a longitudinal multinomial logistic model were performed.

Summarily, the results demonstrated that stakeholders' relationships based on positive reciprocity are positively related to open innovation $\left(\mathrm{H}_{1}\right)$, as well as stakeholders' relationships based on justice $\left(\mathrm{H}_{2}\right)$. Besides, covering the typologies of justice, it has been shown that stakeholders' relationships based on distributive justice $\left(\mathrm{H}_{2 \mathrm{a}}\right)$ and stakeholders' relationships based on interactional justice $\left(\mathrm{H}_{2 b}\right)$ are also positively related to the development of open innovation. However, stakeholders' relationships based on procedural justice $\left(\mathrm{H}_{2 \mathrm{c}}\right)$ were not related to open innovation development. Regarding stakeholders' relationships based on temporal consistency $\left(\mathrm{H}_{3}\right)$, relationships based on temporal consistency of reciprocity $\left(\mathrm{H}_{3} \mathrm{a}\right)$ proved to be positively related to open innovation development; in turn, relationships based on 
the temporal consistency of justice $\left(\mathrm{H}_{3 b}\right)$ were not related to the development of open innovation.

That said, different contributions emerge from this dissertation. The first contribution refers to the identification of the types of relationships with stakeholders that collaborate for the development of open innovation. In consideration of the need for further theoretical deepening on open innovation, its processes, levels and constituent elements (Bogers et al., 2017; Lopes \& Carvalho, 2008; Randhawa, Wilden, \& Hohberger, 2016), the recognition of the roles of these relationships contributes to a greater understanding and clarification of the discussions on the inter-organizational level, knowing about their nature, configuration and integration of key stakeholders (Bogers et al., 2017; Lüttgens et al., 2014).

Given the lack of work that investigates, from the perspective of open innovation, the network of relationships between the various actors as a whole (Flammer \& Kacperczyk, 2016; Randhawa, Wilden, \& Hohberger, 2016; West \& Bogers, 2014), the results of this dissertation contribute by using a synergistic prism (Garcia-Castro \& Francoeur, 2016; Tantalo \& Priem, 2016), considering the investigated relationships as intrinsic and representative of all primary stakeholders.

The third contribution refers to the empirical addition to the Stakeholder Theory, specifically to its microfoundations. By statistically proving the relationship between different classifications of stakeholders' relationships and open innovation, the results of this dissertation demonstrate peculiarities and elements of relationships that motivate stakeholders to collaborate with the organization (Barney \& Felin, 2013; Felin, Foss, \& Ployhart, 2015; Gambeta, Koka, \& Hoskisson, 2019; Garcia-Castro \& Francoeur, 2016), consequently generating better organizational performance (Berman et al., 1999; Harrison, Bosse \& Phillips, 2010; Hillman \& Keim, 2001; Parmar et al., 2010).

In summary, from the perspective of the microfoundations of Stakeholder Theory (Bridoux \& Stoelhorst, 2014; Bosse \& Coughlan, 2016; Hall, Bachor, \& Matos, 2014; Jones, Harrison, \& Phelps, 2018), the main contribution of this study was to provide a model that explains the development of open innovation, emphasizing the importance of the different types of relationships developed with stakeholders, thus answering the request for studies that advance in comprehending the role and motivation of the actors involved in this type of innovation (Bogers et al ., 2017; Lüttgens et al., 2014) and understanding the open innovation relationship network as a whole (Flammer \& Kacperczyk, 2016; Randhawa, Wilden, \& Hohberger, 2016; West \& Bogers, 2014). 
In practical terms, this research guides managers of organizations focused on the development of open innovation, demonstrating which attributes and characteristics to focus efforts and resources in the relationship with stakeholders in order to achieve better organizational performance through the generation of open innovation.

\subsection{Research Limitations}

Despite the theoretical and practical contributions resulting from the present dissertation, it is emphasized that the study has some limitations. The first limitation refers to the database utilized to measure the relationships with stakeholders. Although data used come from reliable and truthful sources (ISE, 2018b) and are applied in researches that address the Stakeholder Theory (Barakat, 2018; Barbosa, 2019; Mascena, 2018), the questionnaire created by ISE was not developed to measure stakeholders' relationships.

The second limitation concerns the use of patents as a proxy for the types of innovation. Although patents are extensively accepted and applied to measure innovation (Baba, Shichijo \& Sedita, 2009; Guan \& Liu, 2016), patents provide limited information regarding their quantity, presence or not of this record and citations. Furthermore, not all innovations developed by organizations necessarily proceed with the patent registration process.

Another limitation refers to the research sample, limited to Brazilian companies listed on B3 and ISE respondents. Before-mentioned characteristics and specificities may incur different environments to encourage innovation and different stakeholders' relationships, perhaps not found in companies that are not able to participate in the ISE portfolio.

\subsection{Recommendations for Future Studies}

Considering the efforts applied to explain the relationship between different types of stakeholders' relationships and open innovation, this dissertation offers an introductory overview for understanding this phenomenon, a panorama that can be extended and expanded through the incorporation of new theoretical elements.

Thus, as a suggestion for future research, considering the limitations of this dissertation, it is proposed: (i) an analysis of data on organizations from different countries, enabling an investigation of country-level factors that can impact open innovation; (ii) use of other databases, such as KLD, with data from more diverse organizations, thus enabling a crosscountry analysis; (iii) adoption of multiple data sources, also obtaining qualitative information 
about open innovation and stakeholders' relationships, which would allow for greater detail about this relation; (iv) development of studies with primary data of the organizations' open innovation, understanding the impact of relationships with stakeholders in the different stages of development of this type of innovation. 


\section{REFERENCES}

Adams, J. S. (1965). Inequity in social exchange. In Berkowitz, L. (Ed.). Advances in experimental social psychology (Vol. 2, pp. 267-299). New York: Academic Press.

Adner, R., \& Kapoor, R. (2010). Value creation in innovation ecosystems: how the structure of technological interdependence affects firm performance in new technology generations. Strategic Management Journal, 31(3), 306-333.

Aghion, P., \& Tirole, J. (1994). The management of innovation. Quartely Journal of Economics, 109(4), 1185-1209.

Aguilera, R. V., Rupp, D. E., Williams, C. A., \& Ganapathi, J. (2007). Putting the S back in corporate social responsibility: a multilevel theory of social change in organizations. Academy of Management Review, 32(3), 836-863.

Alexander, A. T., \& Martin, D. P. (2013). Intermediaries for open innovation: A competencebased comparison of knowledge transfer offices practices. Technological Forecasting \& Social Change, 80(1), 38-49.

Alexy, O., George, G., \& Salter, A. J. (2013). Cui bono? The selective revealing of knowledge and its implications for innovative activity. Academy of Management Review, 38(2), 270291.

Almirall, E., \& Casadesus-Masanell, R. (2010). Open versus closed innovation: a model of discovery and divergence. Academy of Management Review, 35(1), 27-47.

Almirall, E., Lee, M., \& Majchrzak, A. (2014). Open innovation requires integrated competition-community ecosystems: lessons learned from civic open innovation. Business Horizons, 57(3), 391-400.

Antons, D., \& Piller, F. T. (2015). Opening the Black Box of 'Not Invented Here': Attitudes, Decision Biases, and Behavioral Consequences. Academy of Management Perspectives, 29 (2), 193-217.

Appleyard, M. M., \& Chesbrough, H. W. (2017). The dynamics of open strategy: from adoption to reversion. Long Range Planning, 50(3), 310-321.

Arslan, B. (2018). The interplay of competitive and cooperative behavior and differential benefits in alliances. Strategic Management Journal, 39(12), 3222-3246.

Autio, E., Dahlander, L., \& Frederiksen, L. (2013). Information exposure, opportunity evaluation, and entrepreneurial action: an investigation of an online user community. Academy of Management Journal, 56(5), 1348-1371.

Axelrod, R. (2006). The Evolution of Cooperation. New York: Basic Books.

Azoulay, P., Graff Zivin, J.S., \& Manso, G. (2011). Incentives and creativity: Evidence from the academic life sciences. RAND Journal of Economics, 42(3), 527-554.

Baba, Y., Shichijo, N., \& Sedita, S. R. (2009). How do collaborations with universities affect firms' innovative performance? The role of "Pasteur scientists" in the advanced materials field. Research Policy, 38(5), 756-764.

Barakat, S. R. (2018). Capacidades organizacionais e a sinergia na criação de valor para stakeholders. (Doctoral dissertation, University of São Paulo, São Paulo, Brazil). https://teses.usp.br/teses/disponiveis/12/12139/tde-18062018-170624/pt-br.php 
Baregheh, A., Rowley, J., \& Sambrook, S. (2009). Toward a multidisciplinar definition of innovation. Management Decision, 47(8), 1323-1339.

Barbosa, R. A. (2019). Alinhamento da materialidade à distribuição de valor aos stakeholders e sua relação com o desempenho (Doctoral dissertation, University of São Paulo, São Paulo, Brazil). https://www.teses.usp.br/teses/disponiveis/12/12139/tde-28052019155821/pt-br.php

Barney, J. B. (2018). Why resource-based theory's model of profit appropriation must incorporate a stakeholder perspective. Strategic Management Journal, 39(13), 3305-3325.

Barney, J., \& Felin, T. (2013). What are microfoundations? Academy Management Perspectives, 27(2), 138-155.

Battistella, C., de Toni, A. F., \& Pessot, E. (2017). Practising open innovation: a framework of reference. Business Process Management Journal, 23(6), 1311-1336.

Beaulieu, S., \& Pasquero, J. (2002). Reintroducing stakeholder dynamics in stakeholder thinking: a negotiated-order perspective. The Journal of Corporate Citizenship, 6(summer), 53-69.

Belmi, P., \& Pfeffer, J. (2015). How "organization" can weaken the norm of reciprocity: the effects of attributions for favors and a calculative mindset. Academy of Management Discoveries, 1(1), 36-57.

Berchicci, L. (2013). Towards an open R\&D system: internal R\&D investment, external knowledge acquisition and innovative performance. Research Policy, 42(1), 117-127.

Berman, S.L., Wicks, A.C., Kotha, S., \& Jones, T.M. (1999). Does stakeholder orientation matter? The relationship between stakeholder management models and firm financial performance. Academy of Management Journal, 42(5), 488-506.

Bianchi, M., Cavaliere, A., Chiaroni, D., Frattini, F., \& Chiesa, V. (2011). Organisational modes for open innovation in the bio-pharmaceutical industry: an exploratory analysis. Technovation, 31(1), 22-33.

Bies, R. J. (2015). Interactional justice: looking backward, looking forward. In Cropanzano, R. S., \& Ambrose, M. L. (Eds.). The Oxford Handbook of Justice in the Workplace (pp. 3-14). New York: Oxford University Press.

Bignoux, S. (2006). Short-term strategic alliances: A social exchange perspective. Management Decision, 44(5), 615-627.

BM\&FBovespa. (2018). Índice de Sustentabilidade Empresarial (ISE). Retrieved March 30, 2018 from <http://www.bmfbovespa.com.br/pt_br/produtos/indices/indices-desustentabilidade/indice-de-sustentabilidade-empresarial-ise.htm\#panel3a>.

Bogers, M., Zobel, A.-K., Afuah, A., Almirall, E., Brunswicker, S., Dahlander, L., Frederiksen, L., Gawer, A., Gruber, M., Haefliger, S., Hagedoorn, J., Hilgers, D., Laursen, K., Magnusson, M. G., Majchrzak, A., McCarthy, I. P., Moeslein, K. M., Nambisan, S., Piller, F. T., Radziwon, A., Rossi-Lamastra, C., Sims, J., \& Ter Wal, A. L. J. (2017). The open innovation research landscape: established perspectives and emerging themes across different levels of analysis. Industry and Innovation, 24(1), 8-40.

Bogers, M., Afuah, A., \& Bastian, B. (2010). Users as innovators: a review, critique, and future research directions. Journal of Management, 36(4), 857-875. 
Bogers, M., \& Lhuillery, S. (2011). A functional perspective on learning and innovation: investigating the organization of absorptive capacity. Industry and Innovation, 18(6), 581610.

Boiral, O., \& Henri, J.-F. (2017). Is Sustainability Performance Comparable? A Study of GRI Reports of Mining Organizations. Business \& Society, 56(2), 283-317.

Bonaccorsi, A., \& Lipparini, A. (1994). Strategic Partnerships in the new product development: an Italian case study. Journal of Product Innovation Management, 11(2), 134-145.

Bosse, D. A., \& Coughlan, R. (2016). Stakeholder relationship bonds. Journal of Management Studies, 53(7), 1197-1222.

Bosse, D. A., Phillips, R. A., \& Harrison, J. S. (2009). Stakeholders, reciprocity, and firm performance. Strategic Management Journal, 30(4), 447-456.

Bosse, D. A., \& Phillips, R. A. (2016). Agency theory and bounded self-interest. Academy of Management Review, 41(2), 276-297.

Brickson, S. L. (2007). Organizational identity orientations: the genesis of the role of the firm and distinct forms of social value. Academy of Management Review, 32(3), 864-888.

Bridoux, F., \& Stoelhorst, J. W. (2014). Microfoundations for stakeholder theory: Managing stakeholders with heterogeneous motives. Strategic Management Journal, 35(1), 107-125.

Bridoux, F. M., \& Stoelhorst, J. W. (2016). Stakeholder relationships and social welfare: a behavioral theory of contributions to joint value creation. Academy of Management Review, 41(2), 229-251.

Cano-Kollman, M., Hamilton III, R. D., \& Mudambi, R. (2017). Public support for innovation and openness of firms' innovation activities. Industrial and Corporate Change, 26(3), 421442 .

Capaldo, A. (2014). Network governance: a cross-level study of social mechanisms, knowledge benefits, and strategic outcomes in joint-design alliances. Industrial Marketing Management, 43(4), 685-703.

Caputo, M., Lamberti, E., Cammarano, A., \& Michelino, F. (2016). Exploring the impact of the open innovation on firm performances. Management Decision, 54(7), 1788-1812.

Cassiman, B., \& Valentini, G. (2016). Open innovation: are inbound and outbound knowledge flows really complementary? Strategic Management Journal, 37(6), 1034-1046.

Chang, H. H., \& Chuang, S.-S. (2011). Social capital and individual motivations on knowledge sharing: participant involvement as a moderator. Information \& Management, 48(1), 9-18.

Chen, C. J., \& Hung, S. W. (2010). To give or to receive? Factors influencing members' knowledge sharing and community promotion in professional virtual communities. Information \& Management, 47(4), 226-236.

Chen, M.-J., \& Miller, D. (2015). Reconceptualizing competitive dynamics: a multidimensional framework. Strategic Management Journal, 36(5), 758-775.

Chen, Y., Vanhaverbeke, W., \& Du, J. (2016). The interaction between internal R\&D and different types of external knowledge sourcing: an empirical study of Chinese innovative firms. $R \& D$ Management, 46(S3), 1006-1023.

Cheng, C. C. J., \& Huizingh, E. K. R. E. (2014). When is open innovation beneficial? The role of strategic orientation. Journal of Product Innovation Management, 31(6), 1235-1253. 
Chesbrough, H. W. (2003). The era of open innovation. MIT Sloan Management Review, 44(3), $34-42$.

Chesbrough, H. (2004). Managing Open Innovation. Research-Technology Management, 47(1): 23-26.

Chesbrough, H. W. (2006a). Open innovation: the new imperative for creating and profiting from technology. Boston, Massachusetts: Harvard Business School Press.

Chesbrough, H. (2006b). Open innovation: A new paradigm for understanding industrial innovation. In Open Innovation: Researching a New Paradigm, ed. H. Chesbrough, W. Vanhaverbeke, and J. West, 1 - 12. New York, NY: Oxford University Press.

Chesbrough, H. (2011). Open Services Innovation: Rethinking Your Business to Grow and Compete in a New Era. San Francisco, CA: Jossey-Bass.

Chesbrough, H. (2012). Open innovation: where we've been and where we're going. ResearchTechnology Management, 55(4), 20-27.

Chesbrough, H. (2017). The future of open innovation. Research-Technology Management, 60(1), 35-38.

Chiaroni, D., Chiesa, V., \& Frattini, F. (2011). The open innovation journey: how firms dynamically implement the emerging innovation management paradigm. Technovation, 31(1), 34-43.

Cialdini, R. B. (2001). Influence, science, and practice (4th ed.) Boston: Allyn \& Bacon.

Clarkson, M. B. E. (1995). Stakeholder framework for analyzing and evaluating corporate social performance. Academy of Management Review, 20(1), 92-117.

Coff, R. W. (2003). Bidding wars over R\&D-intensive firms: Knowledge, opportunism, and the market for corporate control. Academy of Management Journal, 46(1), 74-85.

Collis, J., \& Hussey, R. (2005). Pesquisa em administração: um guia prático para alunos de graduação e pós-graduação. 2. ed. Porto Alegre: Bookman.

Colquitt, J. A. (2001). On the dimensionality of organizational justice: a construct validation of a measure. Journal of Applied Psychology, 86(3), 386-400.

Colquitt, J. A., \& Rodell, J. B. (2011). Justice, trust, and trustworthiness: a longitudinal analysis integrating three theoretical perspectives. Academy of Management Journal, 54(6), 11831206.

Colquitt, J. A., Conlon, D. E., Wesson, M. J., Porter, C. O. L. H., \& Ng, K. Y. (2001). Justice at the millennium: A meta-analytic review of 25 years of organizational justice research. Journal of Applied Psychology, 86(3), 425-445.

Cova, B., Prévot, F., \& Spencer, R. (2010). Navigating between dyads and networks. Industrial Marketing Management, 39(6), 879-886.

Cropanzano, R., Byrne, Z. S., Bobocel, D. R., \& Rupp, D. E. (2001). Moral virtues, fairness heuristics, social entities, and other denizens of organizational justice. Journal of Vocational Behavior, 58(2), 164-209.

Cropanzano, R., \& Mitchell, M. S. (2005). Social exchange theory: An interdisciplinary review. Journal of Management, 31(6), 874-900. 
Cropanzano, R. S., \& Ambrose, M. L. (2015). Organizational justice: where we have been and where we are going. In Cropanzano, R. S., \& Ambrose, M. L. (Eds.). The Oxford Handbook of Justice in the Workplace (pp. 3-14). New York: Oxford University Press.

Crossan, M. M., \& Apaydin, M. (2010). A multi-dimensional framework of organizational innovation: a systematic review of the literature. Journal of Management Studies, 47(6): 1154-1191.

Cui, A. S., \& Wu, F. (2016). Utilizing customer knowledge in innovation: antecedents and impact of customer involvement on new product performance. Journal of the Academy Marketing Science, 44(4), 516-538.

Dahlander, L., \& Gann, D. M. (2010). How open is innovation? Research Policy, 39(6), 699709.

Dahlander, L., O’Mahony, S., \& Gann, D. M. (2016). One foot in, one foot out: How does individuals' external search breadth affect innovation outcomes? Strategic Management Journal, 37(2), 280-302.

David, P., Hitt., M.A., \& Gimeno, J. (2001). The influence of activism by institutional investors on R\&D. Academy of Management Journal, 44(1), 144-157.

Desouza, K. C., Awazu, Y., Jha, S., Dombrowski, C., Papagari, S., Baloh, P., \& Kim, J. Y. (2008). Customer-Driven Innovation. Research-Technology Management, 51(3), 35-44.

Dew, N., \& Sarasvathy, S. D. (2007). Innovations, stakeholders \& entrepreneurship. Journal of Business Ethics, 74(3), 267-283.

Dingler, A., \& Enkel, E. (2016). Socialization and innovation: insights from collaboration across industry boundaries. Technological Forecasting \& Social Change, 109, 50-60.

Dittrich, K., \& Duysters, G. (2007). Networking as a means to strategy change: the case of open innovation in mobile telephony. The Journal of Product Innovation Management, 24(6), $510-521$.

Dodgson, M., Gann, D., \& Salter, A. (2006). The role of technology in the shift towards open innovation: the case of Procter \& Gamble. $R \& D$ Management, 36(3), 333-346.

Donaldson, T., \& Preston, L. E. (1995). The stakeholder theory of the corporation: concepts, evidence, and implications. Academy of Management Review, 20(1), 65-91.

Dwyer, F. R., Schurr, P. H., \& Oh, S. (1987). Developing buyer-seller relationships. Journal of Marketing, 51(2), 11-27.

Emerson, R. M. (1976). Social exchange theory. Annual Review of Sociology, 2, 335-362.

Enkel, E. (2010). Attributes required for profiting from open innovation in networks. International Journal of Technology Management, 52(3/4), 344-71.

Enkel, E., Gassman, O., \& Chesbrough, H. (2009). Open R\&D and open innovation: exploring the phenomenon. $R \& D$ Management, 39(4), 311-316.

Enkel, E., \& Gassmann, O. (2010). Creative imitation: Exploring the case of cross-industry innovation. $R \& D$ Management, 40(3), 256-70.

Falk, A., \& Fischbacher, U. (2006). A Theory of Reciprocity. Games and Economic Behavior, 54(2), 293-315. 
Fallah, M. H., Lechler, T. G. (2008). Global innovation performance: strategic challenges for multinational corporations. Journal of Engineering and Technology Management, 28(1-2), 58-74.

Fávero, L. P., \& Belfiore, P. (2017). Manual de Análise de Dados: estatística e modelagem multivariada com Excel, SPSS e Stata. Rio de Janeiro: Elsevier.

Fehr, E., \& Falk, A. (2002). Psychological foundations of incentives. European Economic Review, 46(4-5), 687-724.

Fehr, E., \& Gächter, S. (2000). Fairness and retaliation: the economics of reciprocity. Journal of Economic Perspectives, 14(3),159-181.

Felin, T., \& Zenger, T. R. (2014). Closed or open innovation? Problem solving and the governance choice. Research Policy, 43(5), 914-925.

Felin, T., Foss, N. J., \& Ployhart, R. E. (2015). The microfoundations movement in strategy and organization theory. Academy of Management Annals, 9(1), 575-632.

Feller, J., Finnegan, P., Hayes, J., \& O'Reilly, P. (2009). Institutionalising information asymmetry: governance structures for open innovation. Information Technology \& People, 22(4), 297-316.

Feranita, F., Kotlar, J., \& De Massis, A. (2017). Collaborative innovation in family firms: past research, current debates and agenda for future research. Journal of Family Business Strategy, 8(3), 137-156.

Ferreira, J. J. M., Fernandes, C. I., \& Raposo, M. L. (2015). Drivers of innovation strategies: Testing the Tidd and Bessant (2009) model. Journal of Business Research, 68(7), 13951403.

Fisher, G. J., \& Qualls, W. J. (2018). A framework of interfirm open innovation: relationship and knowledge-based perspectives. Journal of Business \& Industrial Marketing, 33(2), 240-250.

Flammer, C., \& Kacperczyk, A. (2016). The impact of stakeholder orientation on innovation: evidence from a natural experiment. Management Science, 62(7), 1982-2001.

Flammer, C., \& Bansal, P. (2017). Does a long-term orientation create value? Evidence from a regression discontinuity. Strategic Management Journal, 38(9), 1827-1847.

Folger, R. (1986). Rethinking equity theory: A referent cognitions model. In Beirhoff, H. W., Cohen, R. L., \& Greenberg, J. (Eds.). Justice in social relations (pp. 145-162). New York: Plenum Press.

Foss, N. J., Lyngsie, J., \& Zahra. S. A. (2013). The role of external knowledge sources and organizational design in the process of opportunity exploitation. Strategic Management Journal, 34(12), 1453-1471.

Fredberg, T., \& Piller, F. T. (2011). The paradox of tie strength in customer relationships for innovation: a longitudinal case study in the sports industry. $R \& D$ Management, 41(5), 470484.

Freeman, R. E. (1984). Strategic management: a stakeholder approach. Boston: Pitman.

Freeman, R. E. (1994). The politics of stakeholder theory: some future directions. Business Ethics Quartely, 4(4), 409-421.

Freeman, R.E., Wicks, A. C., \& Parmar, B. (2004). Stakeholder theory and "the corporate objective revisited". Organization Science, 15(3), 364-369. 
Freeman, R. E., Harrison, J.S., \& Wicks, A. C. (2007). Managing for Stakeholders: Survival, Reputation and Success. Yale University Press: New Haven, CT.

Freeman, R.E., Harrison, J. S., Wicks, A.C., Parmar, B., \& de Colle, S. (2010). Stakeholder theory: the state of the art. Cambrigde: Cambridge University Press.

Freeman, R.E. (2017). Five challenges to stakeholder theory: a report on research in progress. In Stakeholder Management (pp. 1-20). Emerald Publishing Limited

Gambeta, E., Koka, B. R., \& Hoskisson, R. E. (2019). Being too good for your own good: A stakeholder perspective on the differential effect of firm-employee relationships on innovation search. Strategic Management Journal, 40(1), 108-126.

Garcia-Castro, R., \& Aguilera, R. (2015). Incremental value creation and appropriation in a world with multiple stakeholders. Strategic Management Journal, 36(1), 137-147.

Garcia-Castro, R., \& Francoeur, C. (2016). When more is not better: complementarities, costs and contingencies in stakeholder management. Strategic Management Journal, 37(2), 406424.

Gassmann, O. (2006). Opening up the innovation process: towards an agenda. $R \& D$ Management, 36(3), 223-228.

Gassman, O., Enkel, E., \& Chesbrough, H. (2010). The future of open innovation. $R \& D$ Management, 40(3), 213-221.

Gebauer, J., Füller, J., \& Pezzei, R. (2013). The dark and the bright side of co-creation: Triggers of member behavior in online innovation communities. Journal of Business Research, 66(9), 1516-1527.

Gerken, J. M., Moehrle, M. G., \& Walter L. (2015). One year ahead! Investigating the time lag between patent publication and market launch: insights from a longitudinal study in the automotive industry. $R \& D$ Management, 45(3), 287-303.

Gesing, J., Antons, D., Piening, E. P., Rese, M., \& Salge, T. O. (2015). Joining Forces or Going It Alone? On the Interplay among External Collaboration Partner Types, Interfirm Governance Modes, and Internal R\&D. Journal of Product Innovation Management, 32(3), 424-440.

Giuliani, E. (2013). Network dynamics in regional clusters: evidence from Chile. Research Policy, 42(8), 1406-1419.

Goldstein, N. J., Griskevicius, F., \& Cialdini, R. B. (2007). Invoking social norms: A social psychology perspective on improving hotels' linen-reuse programs. Cornell Hotel and Restaurant Administration Quarterly, 48(2), 145-150.

Goldstein, N. J., Griskevicius, V., \& Cialdini, R. B. (2011). Reciprocity by proxy: A novel influence strategy for stimulating cooperation. Administrative Science Quarterly, 56(3), 441-473.

Goodstein, J., \& Butterfield, K. D. (2010). Extending the horizon of business ethics: restorative justice and the aftermath of unethical behavior. Business Ethics Quartely, 20(3), 453-480.

Gould, R. W. (2012). Open innovation and stakeholder engagement. Journal of Technology Management \& Innovation, 7(3), 1-11.

Gouldner, A. W. (1960). The norm of reciprocity: A preliminary statement. American Sociological Review, 25(2), 161-178. 
Greco, M., Grimaldi, M., \& Cricelli, L. (2016). An analysis of the open innovation effect on firm performance. European Management Journal, 34(5), 501-516.

Griffin, J. J. (2016). Managing corporate impacts: co-creating value. New York: Cambridge University Press.

Grossman, G.M., \& Helpman, E. (1994). Endogenous innovation in the theory of growth. Journal of Economic Perspectives, 8(1), 23-44.

Guan, J., \& Liu, N. (2016). Exploitative and exploratory innovations in knowledge network and collaboration network: A patent analysis in the technological field of nano-energy. Research Policy, 45(1), 97-112.

Hahn, T. (2015). Reciprocal stakeholder behavior: a motive-based approach to the implementation of normative stakeholder demands. Business \& Society, 54(1), 9-51.

Hall, J., \& Martin, M. (2005). Disruptive technologies, stakeholders and the innovation value chain: a framework for evaluating radical technology development. $R \& D$ Management, 35(3), 273-284.

Hall, J., Bachor, V., \& Matos, S. (2014). The impact of stakeholder heterogeneity on risk perceptions in technological innovation. Technovation, 34(8), 410-419.

Harrison, J. S., Bosse, D. A., \& Phillips, R. A. (2010). Managing for stakeholders, stakeholder utility functions, and competitive advantage. Strategic Management Journal, 31(1), 58-74.

Harrison, J. S., \& Bosse, D. A. (2013). How much is too much? The limits to generous treatment of stakeholders. Business Horizons, 56(3), 313-322.

Harrison, J. S., \& Wicks, A. C. (2013). Stakeholder theory, value, and firm performance. Business Ethics Quartely, 23(1), 97-124.

Hayibor, S. (2017). Is fair treatment enough? Augmenting the fairness-based perspective on stakeholder behaviour. Journal of Business Ethics, 140(1), 43-64.

Hillman, A.J, \& Keim, GD. (2001). Shareholder value, stakeholder management, and social issues: what's the bottom line? Strategic Management Journal, 22(2), 125-139.

Homans, G. C. (1958). Social behavior as exchange. American Journal of Sociology, 63(6), 597-606.

Hoppner, J. J., \& Griffith, D. A. (2011). The role of reciprocity in clarifying the performance payoff of relational behavior. Journal of Marketing Research, 48(5), 920-928.

Hörisch, J., Freeman, R. E., \& Schaltegger, S. (2014). Applying stakeholder theory in sustainability management: links, similarities, dissimilarities, and a conceptual framework. Organization \& Environment, 27(4), 328-346.

Hu, Y., \& Korneliussen, T. (1997). The effects of personal ties and reciprocity on the performance of small firms in horizontal strategic alliances. Scandinavian Journal of Management, 13(2), 159-173.

Huang, J.-W., \& Li, Y.-H. (2017). Green innovation and performance: the view of organizational capability and social reciprocity. Journal of Business Ethics, 145(2), 309324.

Huizingh, E. K. R. E. (2011). Open innovation: state of the art and future perspectives. Technovation, 31(1), 2-9. 
INPI. (2018). Instituto Nacional da Propriedade Industrial. Retrieved March 30, 2018 from < http://www.inpi.gov.br/sobre/estrutura>.

INPI. (2012). Relatório de Gestão - Prestação de Contas 2011. Retrieved December 23, 2019 from $<$ http://www.inpi.gov.br/acesso-a-

informacao/auditorias/arquivos/relatorio_de_gestao_da_prestacao_de_contas_2011.pdf $>$.

ISE. (2018a). O que é o ISE. Retrieved March 30, 2018 from <http://isebvmf.com.br/o-que-eo-ise?locale $=$ pt-br $>$.

ISE. (2018b). Processo de seleção. Retrieved March 30, 2018 from $<$ http://isebvmf.com.br/processo-de-selecao?locale=pt-br $>$.

Iturrioz, C., Aragón, C., \& Narvaiza, L. (2015). How to foster shared innovation within SMEs' network: social capital and the role of intermediaries. European Management Journal, 33(2), 104-115.

Jap, S. D., \& Anderson, E. (2007). Testing a life-cycle theory of cooperative interorganizational relationships: Movement across stages and performance. Management Science, 53(2), 260-275.

Janeiro, P., Proença, I., \& Gonçalves, V. C. (2013). Open innovation: factors explaining universities as service firm innovation sources. Journal of Business Research, 66(10), 2017-2023.

Jones, T. M. (1995). Instrumental Stakeholder Theory: a synthesis of ethics and economics. Academy of Management Review, 20(2), 404-437.

Jones, T. M., Harrison, J. S., \& Phelps, W. (2018). How applying instrumental stakeholder theory can provide sustainable competitive advantage. Academy of Management Review, 53(3), 371-391.

Kazadi, K., Lievens, A., \& Mahr, D. (2016). Stakeholder co-creation during the innovation process: identifying capabilities for knowledge creation among multiple stakeholders. Journal of Business Research, 69(2): 525-540.

Lamberti, E., Michelino, F., Cammarano, A., \& Caputo, M. (2017). Open innovation scorecard: a managerial tool. Business Process Management Journal, 23(6), 1216-1244.

Laursen, K., \& Salter, A. J. (2006). Open for innovation: the role of openness in explaining innovation performance among U.K. manufacturing firms. Strategic Management Journal, 27(2), 131-150.

Lazzarotti, V., \& Manzini, R. (2009). Different modes of open innovation: a theoretical framework and an empirical study. International Journal of Innovation Management, 13(4), 615-636.

Lee, F., Edmondson, A. C., Thomke, S., \& Worline, M. (2004). The mixed effects of inconsistency on experimentation in organizations. Organization Science, 15(3), 310-326.

Lee, S. M., Olson, D. L., \& Trimi, S. (2012) Co-innovation: convergenomics, collaboration, and co-creation for organizational values. Management Decision, 50(5), 817-831.

Leiponen, A., \& Helfat, C. A. 2010. Innovation objectives, knowledge sources, and the benefits of breadth. Strategic Management Journal, 31(2): 224-236.

Leventhal, G. S. (1976). The distribution of rewards and resources in groups and organizations. In: Berkowitz, L., \& Walster, W. (eds.). Advances in experimental social psychology, 9, 91-131. 
Leventhal, G. S. (1980). What should be done with equity theory? New approaches to the study of fairness in social relationships. In: Gergen, K. J., Greenberg, M. S., \& Willis, R. H. (eds). Social Exchange: Advances in Theory and Research. New York: Plenum Press.

Levine, S. S., \& Prietula, M. J. (2014). Open collaboration for innovation: principles and performance. Organization Sciente, 25(5), 1-20.

Levinson, H. (1965). Reciprocation: The Relationship between Man and Organization. Administrative Science Quartely, 9(4), 370-390.

Li, J., Xia, J., \& Zajac, E. (2018). On the duality of political and economic stakeholder influence on firm innovation performance: Theory and evidence from Chinese firms. Strategic Management Journal, 39(1): 193-216.

Lichtenthaler, U. (2008). Open innovation in practice: an analysis of strategic approaches to technology transactions. IEEE Transactions on Engineering Management, 55(1), 148-157.

Lichtenthaler, U. (2011). Open innovation: past research, current debates, and future directions. Academy of Management Perspectives, 25(1), 75-93.

Lin, M. J., Hung, S. W., \& Chen, C. J. (2009). Fostering the determinants of knowledge sharing in professional virtual communities. Computers in Human Behavior, 25(4), 929-939.

Lind, E. A. (2001). Fairness heuristic theory: Justice judgments as pivotal cognitions in organizational relations. In: Greenberg, J., \& Cropanzano, R. (Eds.). Advances in organizational justice (pp. 56-88). Stanford: Stanford University Press

Liu, Y.-H. S., Deligonul, S., Cavusgil, E., \& Chiou, J-S. (2018). Always trust in old friends? Effects of reciprocity in bilateral asset specificity on trust in international B2B partnership. Journal of Business Research, 90 (september), 171-185.

Lopes, A. P. V. B. V., \& Carvalho, M. M. (2018). Evolution of the open innovation paradigm: towards a contingent conceptual model. Technological Forecasting \& Social Change, 132(July), 284-298.

Lopez-Vega, H., Tell, F., \& Vanhaverbeke, W. (2016). Where and how to search? Search paths in open innovation. Research Policy, 45(1), 125-136.

Love, J. H., Roper, S., \& Vahter, P. (2014). Learning from openness: the dynamics of breadth in external innovation linkages. Strategic Management Journal, 35(11), 1703-1716.

Luo, Y. (2007). The independent and interactive roles of procedural, distributive, and interactional justice in strategic alliances. Academy of Management Journal, 50(3), 644664.

Luo, X., \& Bhattacharya, C.B. (2006). Corporate social responsibility, customer satisfaction, and market value. Journal of Marketing, 70(4), 1-18.

Lusch, R. F., \& Brown, J. R. (1996). Interdependency, contracting, and relational behavior in marketing channels. Journal of Marketing, 60(Oct), 19-38.

Lüttgens, D., Pollok, P., Antons, D., \& Piller, F. (2014). Wisdom of the crowd and capabilities of a few: internal success factors of crowdsourcing for innovation. Journal of Business Economics, 84(3), 339-374.

Mainardes, E. W., Alves, H., \& Raposo, M. (2011). Stakeholder theory: issues to resolve. Management Decision, 49(2), 226-252.

Manso, G. (2011). Motivating innovation. Journal of Finance, 66(5),1823-1860. 
Martinez, F. (2019). On the role of faith in sustainability management: a conceptual model and research agenda. Journal of Business Ethics, 155(3), 787-807.

Martinez-Conesa, I., Soto-Acosta, P., \& Carayannis, E. G. (2017). On the paths towards open innovation: assessing the role of knowledge management capability and environmental dynamism in SMEs. Journal of Knowledge Management, 21(3), 553-570.

Mascena, K. M. C. (2018) Distribuição de valor para stakeholders e desempenho financeiro corporativo (Doctoral dissertation, University of São Paulo, São Paulo, Brazil). https://teses.usp.br/teses/disponiveis/12/12139/tde-12062018-113757/pt-br.php

McVea, J. F., \& Freeman, R. E. (2005). A names-and-faces approach to stakeholder management. Journal of Management Inquiry, 14(1), 57-69.

Meireles, F. R. S., Boaventura, J. M. G., \& Griffin, J. J. (2019). Stakeholders' relationships as a microfoundation for open innovation. 79th Annual Meeting of Academy of Management, Chicago, IL.

Melé, D. (2014). "Human quality treatment": five organizational levels. Journal of Business Ethics, 120(4), 457-471.

Mitchell, R. K., Agle, B. R., \& Wood, D. J. (1997). Toward a theory of stakeholder identification and salience: defining the principle of who and what really counts. Academy of Management Review, 22(4), 853-886.

Mooi, E. A., \& Frambach, R. T. (2012). Encouraging innovation in business relationships - A research note. Journal of Business Research, 65(7), 1025-1030.

Muthusamy, S. K., \& White, M. A. (2005). Learning and knowledge transfer in strategic alliances: A social exchange view. Organization Studies, 26(3), 415-441.

Neuhaus, J. M. (1992). Statistical methods for longitudinal and clustered designs with binary responses. Statistical Methods in Medical Research, 1(3), 249-273.

Nieto, M. J., \& Santamaría, L. (2007). The importance of diverse collaborative networks for the novelty of product innovation. Technovation, 27(6-7), 367-377.

OECD. (2005). Oslo Manual: guidelines for collecting and interpreting innovation data. 3rd edition. Paris: OECD.

Oliver, C. (1991). Strategic response to institutional processes. Academy of Management Review, 16(1), 145-179.

Park, S. (2015). Evaluating the efficiency and productivity change within government subsidy recipients of a national technology innovation research and development program. $R \& D$ Management, 45(5), 549-568.

Parmar, B. L., Freeman, R. E., Harrison, J. S., Wicks, A. C., Purnell, L., \& de Colle, S. (2010). Stakeholder theory: the state of the art. The Academy of Management Annals, 4(1), 403445.

Paulo, A. F., Carvalho, L. C., Costa, M. T. G. V., \& Galina, S. V. R. (2017). Mapping open innovation: a bibliometric review to compare developed and emerging countries. Global Business Review, 18(2), 291-307.

Perkmann, M., \& Walsh, K. (2007). University-industry relationships and open innovation: towards a research agenda. International Journal of Management Reviews, 9(4), 259-280. 
Pervan, S. J., Bove, L. L., \& Johson, L. W. (2009). Reciprocity as a key stabilizing norm of interpersonal marketing relationships: scale development and validation. Industrial Marketing Management, 38(1), 60-70.

Pforr, K. (2014). Femlogit-Implementation of the multinomial logit model with fixed effects. The Stata Journal, 14(4), 847-862.

Phillips, R. A. (1997). Stakeholder theory and a principle of fairness. Business Ethics Quarterly, 7(1), 51-66.

Phillips, R. (2003). Stakeholder theory and organizational ethics. San Francisco: BerrettKoehler Publishers.

Phillips, R., Freeman, R. E., \& Wicks, A. C. (2003). What stakeholder theory is not. Business Ethics Quartely, 13(4), 479-502.

Porter, M. (1990). The Competitive Advantage of Nations. New York: Free Press.

Priem, R. L., Krause, R., Tantalo, C., \& McFadyen, M. A. (2019). Promoting long-term shareholder value by "competing" for essential stakeholders: a new, multi-sided market logic for top managers. Academy of Management Perspectives, In-Press. https://doi.org/10.5465/amp.2018.0048

Quintane, E., Casselman, R. M., Reiche, B. S., \& Nylund, P. A. (2011). Innovation as a knowledge-based outcome. Journal of Knowledge Management, 15(6), 928-947.

Ram, J., Cui, B., \& Wu, M.-L. (2010). The Conceptual Dimensions of Innovation: A Literature Review. International Conference on Business and Information, Sapporo, Japan, 3rd-5th July, 2010.

Randhawa, K., Wilden, R., \& Hohberger, J. (2016). A bibliometric review of open innovation: setting a research agenda. Journal of Product Innovation Management, 33(6), 750-772.

Rawls, J. (1971). A Theory of Justice. Harvard Business Press: Cambridge, MA.

Rohrbeck, R., Hölzle, K., \& Gemünden, H. G. (2009). Opening up for competitive advantage: how Deutsche telekom creates an open innovation ecosystem. R\&D Management, 39(4), 420-430.

Rowley, T. J. (1997). Moving beyond dyadic ties: a network theory of stakeholder influences. Academy of Management, 22(4), 887-910.

Salem, M. A., Shawtari, F. A., Shamsudin, M. F., \& Hussain, H. I. (2016). The relation between stakeholders' integration and environment competitiveness. Social Responsibility Journal, 12(4), 755-769.

Sampieri, R. H., Collado, C. F., \& Lucio, P. B. (2013). Metodologia de pesquisa. 5. ed. Porto Alegre: Penso.

Schumpeter, J.A. (1942). Capitalism, Socialism, and Democracy. New York: Harper \& Brothers.

Sharifi, H., Ismail, H.S., \& Reid, I. (2006). Achieving agility in supply chain through simultaneous "design of" and "design for" supply chain. Journal of Manufacturing Technology Management, 17(8), 1078-1098.

Sen, S., \& Bhattacharya, C.B. (2001). Does doing good always lead to doing better? Consumer reactions to corporate social responsibility. Journal of Marketing Research, 38(2), 225243. 
Simeone, L., Secundo, G., \& Schiuma, G. (2017). Knowledge translation mechanisms in open innovation: the role of design in R\&D projects. Journal of Knowledge Management, 21(6), 1406-1429.

Sluss, D. M., \& Ashforth, B. E. (2008). How relational and organizational identification converge: Processes and conditions. Organization Science, 19(6), 807-823.

Spender, J.-C., Corvello, V., Grimaldi, M., \& Rippa, P. (2017). Startups and open innovation: a review of the literature. European Journal of Innovation Management, 20(1), 4-30.

Spithoven, A., Vanhaverbeke, W., \& Roijakkers, N. (2013). Open innovation practices in SMEs and large enterprises. Small Business Economics, 41(3), 537-562.

Stacchezzini, R., Melloni, G, \& Lai, A. (2016). Sustainability management and reporting: the role of integrated reporting for communicating corporate sustainability management. Journal of Cleaner Production, 136(Part A), 102-110.

Stankevičienè, J., \& Vaiciukevičiūtè, A. (2016). Value creation for stakeholders in higher education management. Ekonomika a Management, 19(1), 17-32.

Surroca, J., Tribó, J. A., \& Waddock, S. (2010). Corporate responsibility and financial performance: the role of intangible resources. Strategic Management Journal, 31(5), 463490.

Susnienè, D., \& Vanagas, P. (2006). Development of stakeholder relationships by integrating their needs into organizations' goals. Engineering Economics, 48(3), 83-87.

Susnienè, D., \& Vanagas, P. (2007). Means for satisfaction of stakeholders' needs and interests. Engineering Economics, 55(5), 24-28.

Swärd, A. (2016). Trust, reciprocity, and actions: the development of trust in temporary interorganizational relations. Organization Studies, 37(12), 1841-1860.

Tantalo, C., \& Priem, R. L. (2016). Value creation through stakeholder synergy. Strategic Management Journal, 37 (2), 314-329.

Tavani, S. N., Sharifi, H., Soleimanof, S., \& Najmi, M. (2013). An empirical study of firm's absorptive capacity dimensions, supplier involvement and new product development performance. International Journal of Production Research, 51(11), 3385-3403.

Tsaur, S.-H., \& Wang, C.-H. (2011). Personal ties, reciprocity, competitive intensity, and performance of the strategic alliances in Taiwan's travel industry. The Service Industries Journal, 31(6), 911-928.

Un, C. A., Cuervo-Cazurra, A., \& Asakawa, K. (2010). R\&D collaborations and product innovation. Journal of Product Innovation Management, 27(5), 673-89.

van der Borgh, M., Cloodt, M., \& Romme, A. G. L. (2012). Value creation by knowledge-based ecosystems: evidence from a field study. R\&D Management, 42(2), 150-169.

Veer, T., Lorenz, A., \& Blind, K. (2016). How open is too open? The mitigating role of appropriation mechanisms in $\mathrm{R} \& \mathrm{D}$ cooperation settings. $R \& D$ Management, 43(S3), 11131128.

Wang, C.-H., Cheng, C.-H., \& Shen, G. C. (2015). The effect of inbound open innovation on firm performance: Evidence from high-tech industry. Technological Forecasting \& Social Change, 99, 222-230. 
Wang, H., \& Choi, J. (2013). A new look at the corporate social-financial performance relationship: the moderating roles of temporal and interdomain consistency in corporate social performance. Journal of Management, 39(2), 416-441.

Wasko, M. M., \& Faraj, S. (2005). Why should I share? Examining social capital and knowledge contribution in electronic networks of practice. MIS Quarterly, 29(1), 35-57.

Weber, R. P. (1990). Basic content analysis. Newbury Park, CA: Sage.

West, J. \& Bogers, M. (2014). Leveraging external sources of innovation: a review of research on open innovation. Journal of Product Innovation Management, 31(4), 814-831.

West, J., \& Gallagher, S. (2006). Challenges of open innovation: the paradox of firm investment in open-source software. $R \& D$ Management, 36(3), 319-331.

West, J., \& Lakhani, K. R. (2008). Getting clear about communities in open innovation. Industry and Innovation, 15(2), 223-231.

Wicks, A. C., Berman, S. L, \& Jones, T. M. (1999). The structure of optimal trust: moral and strategic implications. Academy of Management Review, 24(1), 99-116.

Wincent, J., Anokhin, S., Örtqvist, D., \& Autio, E. (2010). Quality meets structure: Generalized reciprocity and firm-level advantage in strategic networks. Journal of Management Studies, 47(4), 597-624.

Zhang, J. Z., Watson, I. G. F., Palmatier, R. W., \& Dant, R. P. (2016). Dynamic relationship marketing. Journal of Marketing, 80(5), 53-75.

Zobel, A.-K., Balsmeier, B., \& Chesbrough, H. (2016). Does patenting help or hinder open innovation? Evidence from new entrants in the solar industry. Industrial and Corporate Change, 25(2), 307-331. 


\section{APPENDIX A - ISE QUESTIONS 2017/2018 SELECTED TO MEASURE STAKEHOLDERS' RELATIONSHIPS BASED ON POSITIVE RECIPROCITY}

\section{Economic and Financial Dimension}

ECO 11. Select the alternatives that characterize the company's practices about the financial statements:

a) It does not prepare monetarily updated financial statements but prepares monetarily updated management reports for internal use

b) It prepares the financial statements updated monetarily, but they are not published

c) It prepares and publishes the monetarily updated financial statements

d) It does not make monetary adjustment

ECO 12. The Explanatory Notes quantify:
a) Post-employment benefits
b) Social and Environmental Risk Management
c) None of the above

\section{$\underline{\text { General Dimension }}$}

GER 1. Is the commitment to Sustainable Development formally inserted in the company's culture and strategy?

\section{(GRI G4) Organizational Profile 1 e Ethics and Integrity 56}
a) Yes
b) No

GER 1.2. If the answer was YES for QUESTION 1, select the themes expressly contemplated in this commitment:

(Select one or more alternatives)

\section{(ISO 26000) Table 2}
a) Respect for the environment
b) Fair operating practices
c) Promotion of Human Rights

${ }^{1}$ Translated by the author. 
d) Improvement of working, employment and income conditions

e) Relationships with customers and consumers

f) Involvement with the community and its development

g) Organizational Governance

h) Fight against corruption

i) Reduction of social inequalities

j) None of the above

GER 1.3. If the answer was YES for QUESTION 1, does the company have an awareness and education program on the topic?
a) Yes
b) No

GER 1.3.1. If the answer was YES for QUESTION 1.3, this program effectively reaches:

(Select one or more alternatives)
a) Internal audience at management level and leadership
b) Internal audience of all other levels
c) Critical suppliers
d) All other suppliers
e) Consumers and/or customers
f) Stakeholders other than those mentioned above

\section{Corporate Governance Dimension}

GOV 4. Does the company's Bylaws establish arbitration as a means of resolving corporate conflicts?
a) Yes
b) No

GOV 5. Do the Bylaws clearly provide that the economic and financial bases for the shareholders' recess, delisting, and the withdrawal of a B3 listing segment are not inferior to the economic value?
a) Yes, it provides economic value for all shareholders, except for cases of shareholder recess
b) Yes, it provides economic value for all shareholders
${ }^{1}$ Translated by the author. 
c) No

GOV 24. Is there a formal process for assessing the performance of the chief executive by the Board of Directors, at least annually?

(GRI G4) Organizational Profile 45 and 47
a) Yes
b) No

GOV 26. There is an updated and formalized succession plan, approved by the Board of Directors, for:

(Select one or more alternatives)
a) Chief Executive
b) Other key company executives
c) There are no updated succession plans

GOV 28. Regarding the Audit Committee, indicate the alternatives that apply: (Select one or more alternatives)

a) It is formally established in the bylaws

b) It has a majority (or all) of independent advisors in its composition

c) It has at least one member specialized in accounting matters, internal controls, financial information and operations, and independent auditing

d) It is coordinated by an independent advisor

e) It does not have advisors who accumulate executive functions in the organization in its composition

f) It has no organization executives as committee members

g) It does not have an Audit Committee

GOV 32. Does the Board of Directors ensure that the internal control system is evaluated at least annually?
a) Yes
b) No 
GOV 34. Is there a Fiscal Council installed?

a) Yes, there is an "Improved" Fiscal Council, on a permanent basis

b) Yes, on a non-permanent basis

c) Yes, on a permanent basis

d) No

\section{Nature of the Product Dimension}

NAT 1. Can the consumption or regular use of products and services by the company or its subsidiaries cause:

- death of the user/consumer or third parties, and/or

- chemical or psychological dependence of the user/consumer, and/or

- risks or damage to the health and physical integrity of the user/consumer or third parties?

(ISO 26000) Subsections 4.8, 6.3 and 6.7
a) Yes
b) No

NAT 1.2. If the answer was NO for QUESTION 1, does the company finance or invest in companies that produce or sell this type of product?
a) Yes
b) No

\section{Society Dimension}

SOC 1. Select the topics for which the company has a formal commitment:

(Select one or more alternatives)

(GRI G4) Indicators HR1, HR3, HR4, HR5, HR6 and HR10

(ISO 26000) Subsection 4.7
a) Eradication of child labor (TI)
b) Eradication of forced or compulsory labor (TF)
c) Combating discrimination in all its forms (DI)
d) Appreciation of diversity (DV)
e) Prevention of bullying and sexual harassment (AS)
f) Respect for free union association and the right to collective bargaining (LA)
g) None of the above 
SOC 1.2. Regarding the commitments indicated in QUESTION 1, indicate which actions are explicitly contemplated in the referred document(s):

(P) Answer considering:

TI - Eradication of child labor

TF - Eradication of forced or compulsory labor

DI - Combating discrimination in all its forms

DV - Appreciation of diversity

AS - Prevention of bullying and sexual harassment

LA - Respect for free union association and the right to collective bargaining

\begin{tabular}{|l|l|l|l|l|l|}
\hline ACTION & $\begin{array}{c}\text { TI and } \\
\text { TF }\end{array}$ & $\begin{array}{c}\text { DI and } \\
\text { DV }\end{array}$ & AS & LA & None \\
\hline $\begin{array}{l}\text { a) Establishment of guidelines related to the management of the } \\
\text { company with a view to the theme focused on the commitment }\end{array}$ & & & & & \\
\hline $\begin{array}{l}\text { b) Prevention of direct involvement in situations that contradict the } \\
\text { commitment assumed }\end{array}$ & & & & & \\
\hline c) It contemplates the promotion of this commitment in its value chain & & & & & \\
\hline d) Establishes guidelines for management along your supply chain & & & & & \\
\hline
\end{tabular}

SOC 1.4. Does the company have a formal commitment to combating the sexual exploitation of children and adolescents?

a) Yes, for the whole company

b) Yes, for the entire company and with a corporate policy for its effective adoption

c) Yes, with a corporate policy for its effective adoption and specifying sectors and activities that require greater care, in the company and its suppliers

d) No

SOC 2.2. Is the corporate policy that addresses the issue of relationship with the local community available in the free access area of the company's website?

a) Yes

b) No

SOC 4. Does the company have a corporate policy aimed at preventing information about customers/consumers or other parties with whom it relates in the course of its usual activities or in its commercial efforts from being used in an unauthorized manner, in order to preserve the privacy of the customer/consumer and of the citizen in general?

(Select one or more alternatives)

${ }^{1}$ Translated by the author. 
(GRI G4) Indicator PR8

(ISO 26000) Subsection 6.7.7

a) Yes, including guidance for areas responsible for commercial activity (such as marketing and sales)

b) Yes, including guidance for the areas responsible for collecting, storing and analyzing data (such as information technology and systems)

c) Yes, identifying those responsible for implementing and complying with this policy

d) Yes, establishing sanctions for those responsible for failures in applying this policy

e) No

SOC 15. Does the company promote Private Social Investment (PSI) initiatives?

(GRI G4) Indicator EC1 and EC7

(ISO 26000) Subsection 6.8.9
a) Yes
b) No

SOC 15.1. If the answer was YES for QUESTION 15, about the relationship between social investments and public policies and/or collective agendas for sustainable development, the company:

(Select one or more alternatives)

a) Considers them as a general reference for defining social investments, but without direct impact on policies

b) Operates in partnership with the government at the municipal, state or federal level in the formulation or execution of any public policy

c) Operates in partnership with the community and other stakeholders in the formulation or execution of any collective agenda

d) Does not consider them in the construction or implementation of its social investments

SOC 15.2. If the answer was YES for QUESTION 15, among the criteria for defining social investments, the company considers the importance of obtaining concrete results, and considers:

(Select one or more alternatives) 
a) The evaluation of the results of the supported initiatives

b) The audit on the results and management of the supported initiatives

c) Creation of conditions for financial and organizational self-sufficiency of projects (long term view)

d) None of the above

SOC 15.4. If the answer was YES for QUESTION 15, does the company make social investments with available resources through tax incentives?

a) Yes

b) No

SOC 18.2. Respond if the company has its products and services predominantly aimed at individuals. In its service to meet consumer demands, the company:

(Select one or more alternatives)

(GRI G4) Indicator PR5

(ISO 26000) Subsection 6.7.6

a) Monitors the performance of this process by subject and problem

b) Establishes and monitors compliance with deadlines agreed with the customer/consumer

c) Encourages and favors the use of this access channel by the target audience

d) Enables service with flexibility and customization, with resolving power compatible with the demands of users

e) provides a secondary service channel, in cases where the main customer/consumer service channel has not resolved the demand

f) None of the above

SOC 20. Regarding the difference in proportion between management positions held by men and women, the company:

(GRI G4) Indicator LA12

(ISO 26000) Subsection 6.3.7

a) Has a medium-term goal (3 years) to reduce this difference in proportion, to a value less than 0.9 or greater than 1.1 , to both genders

b) Has a medium-term goal ( 3 years) to reduce this difference in proportion to a value between 0.9 and 1.1 , for both genders

${ }^{1}$ Translated by the author. 
c) Does not present goals, since the difference in proportion is already between 0.9 and 1.1 , for both genders

d) Does not establish goals

SOC 21. Regarding the proportion of the difference between executive positions held by men and women, the company:

(GRI G4) Indicator LA12

(ISO 26000) Subsection 6.3.7

a) Has a medium-term goal (3 years) to reduce this difference in proportion, to a value less than

0.9 or greater than 1.1 , to both genders

b) Has a medium-term goal ( 3 years) to reduce this difference in proportion to a value between 0.9 and 1.1, for both genders

c) Does not present goals, since the difference in proportion is already between 0.9 and 1.1 , for both genders

d) Does not establish goals

SOC 22. Regarding the proportion of difference between management positions occupied by blacks (as) and people of other races/colors, the company:

(GRI G4) Indicator LA12

(ISO 26000) Subsection 6.3.7

a) Has a medium-term goal (3 years) to reduce this difference in proportion, to a value below 0.9 or higher than 1.1, for the different race/color groups existing in the regions where the company operates

b) Has a medium-term goal (3 years) to reduce this difference in proportion to a value between 0.9 and 1.1 , for the different race/color groups existing in the regions where the company operates

c) Does not present goals, since the difference in proportion is already in a value between 0.9 and 1.1 , for the different race/color groups existing in the regions where the company operates d) Does not establish goals

SOC 23. Regarding the proportion of the difference between executive positions held by blacks and people of other races / colors, the company: 
(GRI G4) Indicator LA12

(ISO 26000) Subsection 6.3.7

a) Has a medium-term goal ( 3 years) to reduce this difference in proportion, to a value below 0.9 or higher than 1.1 , for the different race/color groups existing in the regions where the company operates

b) Has a medium-term goal (3 years) to reduce this difference in proportion to a value between 0.9 and 1.1, for the different race/color groups existing in the regions where the company operates

c) Does not present goals, since the difference in proportion is already in a value between 0.9 and 1.1 , for the different race/color groups existing in the regions where the company operates

d) Does not establish goals

e) Not available

SOC 25. Regarding the difference in the remuneration of people occupying management positions and executive positions associated with the gender, the company:

(GRI G4) Indicator LA13

(ISO 26000) Subsection 6.4.3

a) Has a short-term goal to place its Equity Factor in Remuneration in the range between 0.9 and 1.1

b) Has a medium-term goal of placing its Equity Factor in Remuneration in the range between

0.9 and 1.1

c) Has different goals for these

d) Is in the range between 0.9 and 1.1

e) Has no goals

SOC 26. Regarding the difference in the remuneration of people occupying management positions and executive positions associated with race/color, the company:

(GRI G4) Indicator LA12

(ISO 26000) Subsection 6.4.3

a) Has a short-term goal to place its Equity Factor in Remuneration in the range between 0.9 and 1.1

b) Has a medium-term goal of placing its Equity Factor in Remuneration in the range between

0.9 and 1.1

${ }^{1}$ Translated by the author. 
c) Has different goals for these

d) Is in the range between 0.9 and 1.1

e) Has no goals

SOC 35. Does the company maintain management practices for its suppliers that make it possible to identify and monitor critical suppliers, from the point of view of sustainability?

(GRI G4) Indicator G4-12, EN32 to EN34, LA14 to LA16, HR4 to HR6, HR10 to HR12, and SO9 to SO11

a) Yes

b) No

SOC 35.1. If the answer was YES for QUESTION 35, based on the total number of critical suppliers active during the last year, indicate a percentage that corresponds to those included in each of the indicated activities:

\begin{tabular}{|c|c|c|c|c|}
\hline ACTIVITY & $0 \%$ & $\leq 25 \%$ & $>25 \%$ e $\leq 75 \%$ & $>75 \%$ \\
\hline $\begin{array}{c}\text { a) Activities } \\
\text { promoted by the } \\
\text { company, aimed at } \\
\text { raising awareness } \\
\text { of issues related to } \\
\text { sustainability, as } \\
\text { well as sharing } \\
\text { visions and } \\
\text { commitments }\end{array}$ & & & & \\
\hline $\begin{array}{l}\text { b) Support for the } \\
\text { development of } \\
\text { productive and } \\
\text { managerial } \\
\text { practices aimed at } \\
\text { sustainability, } \\
\text { including } \\
\text { adaptation to the } \\
\text { company's } \\
\text { demands }\end{array}$ & & & & \\
\hline $\begin{array}{c}\text { c) Suppliers } \\
\text { eligible for } \\
\text { recognition through } \\
\text { awards or } \\
\text { communication } \\
\text { campaigns that } \\
\text { value the adoption } \\
\text { of socio- } \\
\text { environmental } \\
\text { practices }\end{array}$ & & & & \\
\hline $\begin{array}{l}\text { d) Management } \\
\text { processes } \\
\text { (approval, } \\
\text { selection, etc.) that }\end{array}$ & & & & \\
\hline
\end{tabular}

${ }^{1}$ Translated by the author. 


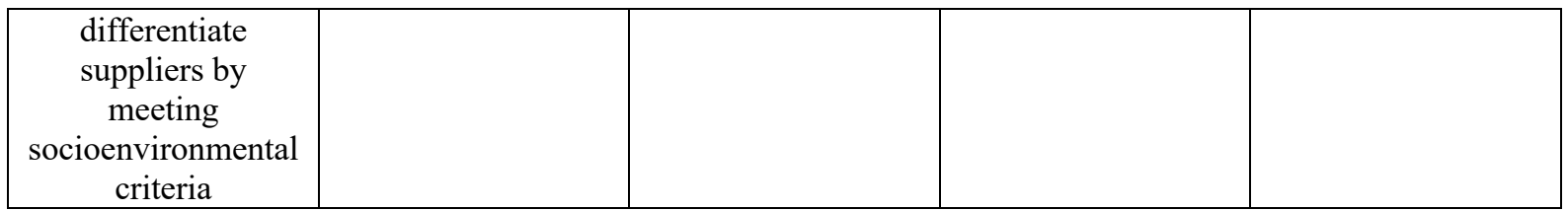

SOC 37. Please indicate the business volume carried out with suppliers that are monitored by the company and subject to independent external verification, based on each of the principles below:

(GRI G4) Indicator G4-12, EN32 to EN34, LA14 to LA16, HR4 to HR6, HR10 to HR12, and SO9 to SO11

\begin{tabular}{|c|c|c|c|c|}
\hline & $0 \%$ & $\leq 25 \%$ & $>25 \%$ e $\leq 75 \%$ & $>75 \%$ \\
\hline \multicolumn{5}{|l|}{$\begin{array}{l}\text { a) No use of child } \\
\text { labor }\end{array}$} \\
\hline $\begin{array}{l}\text { b) No use of forced } \\
\text { or compulsory } \\
\text { labor }\end{array}$ & & & & \\
\hline $\begin{array}{l}\text { c) Valuing } \\
\text { diversity }\end{array}$ & & & & \\
\hline $\begin{array}{l}\text { d) Combating the } \\
\text { practice of } \\
\text { discrimination }\end{array}$ & & & & \\
\hline $\begin{array}{l}\text { e) Punctual and } \\
\text { correct payment of } \\
\text { your obligations to } \\
\text { suppliers, } \\
\text { employees and } \\
\text { taxes }\end{array}$ & & & & \\
\hline
\end{tabular}

${ }^{1}$ Translated by the author. 


\section{APPENDIX B - ISE QUESTIONS 2017/2018 SELECTED TO MEASURE STAKEHOLDERS' RELATIONSHIPS BASED ON JUSTICE}

\section{$\underline{\text { Stakeholders' Relationships Based on Distributive Justice }}$}

ECO 10. Is there a performance management system based on indicators linked to strategic planning?
a) Yes
b) No

ECO 14. Does the company calculate economic profit or other measures to generate economic value?
a) Yes
b) No

SOC 11. When establishing the remuneration of its employees, the company:

(Select one or more alternatives)

(GRI G4) Indicator EC5

(ISO 26000) Subsection 6.4.4

a) Considers the relationship between the lowest salary in the company and the current minimum wage and/or the local cost of living for establishing employee remuneration

b) Includes research to measure employee satisfaction with the remuneration and benefits offered by the company

c) Includes representative union(s) of employee(s) in the negotiation of their salary policy, in addition to the negotiation of adjustments in the base dates of each category

d) None of the above

SOC 27. Does the company disclose in its Sustainability Report the ratio between the highest salary paid and the average salary of all other company employees?

\section{(GRI G4) Indicator 54 and EC5}
a) Yes
b) No 
SOC 29. Does the company establish goals to reduce the distance between the highest and lowest paid remuneration?

(ISO 26000) Subsection 6.4.4

a) Yes, but do not publish them

b) Yes, and publish them

c) It is subject to legislation that prevents this type of management

d) No

\section{Stakeholders' Relationships Based on Interactional Justice}

GER 1.1. The commitment to Sustainable Development is formally expressed:

(Select one or more alternatives)

(ISO 26000) Subsection 7.4

a) In the Vision, or statement of a similar nature

b) In the Mission, or statement of a similar nature

c) In the Code of Conduct that explains the values and principles that guide the company's operation

d) In the organization's policies

e) In the objectives and goals of socio-environmental performance assumed in a public and formal document

f) None of the above

SOC 1.1. Please indicate how this formal commitment is expressed:

TI - Eradication of child labor

$\mathrm{TF}$ - Eradication of forced or compulsory labor

DI - Combating discrimination in all its forms

DV - Appreciation of diversity

AS - Prevention of bullying and sexual harassment

LA - Respect for free union association and the right to collective bargaining

\begin{tabular}{|c|c|c|c|c|c|}
\hline Document & $\begin{array}{l}\text { TI and } \\
\text { TF }\end{array}$ & $\begin{array}{l}\text { DI and } \\
\text { DV }\end{array}$ & AS & LA & None \\
\hline a) Code of conduct & & & & & \\
\hline b) Corporate Policy that addresses the theme & & & & & \\
\hline $\begin{array}{l}\text { c) Formal adherence or public statement regarding voluntary } \\
\text { commitments and initiatives on the topic }\end{array}$ & & & & & \\
\hline
\end{tabular}

\footnotetext{
${ }^{1}$ Translated by the author.
} 
SOC 1.3. Regarding formal commitments, indicate the options adopted for their broad dissemination:

TI - Eradication of child labor

$\mathrm{TF}$ - Eradication of forced or compulsory labor

DI - Combating discrimination in all its forms

DV - Appreciation of diversity

AS - Prevention of bullying and sexual harassment

LA - Respect for free union association and the right to collective bargaining

\begin{tabular}{|c|c|c|c|c|c|}
\hline PROVIDENCES OF THE WIDE DISCLOSURE PROCESS & $\begin{array}{c}\text { TI } \\
\text { and } \\
\text { TF }\end{array}$ & $\begin{array}{l}\text { DI } \\
\text { and } \\
\text { DV }\end{array}$ & AS & LA & None \\
\hline \multicolumn{6}{|l|}{ a) Publication in the free access area of the company's website } \\
\hline \multicolumn{6}{|l|}{$\begin{array}{l}\text { b) Publication of versions adapted for audiences with specific } \\
\text { accessibility needs }\end{array}$} \\
\hline $\begin{array}{l}\text { c) Promotion of actions aimed at attracting attention and facilitating } \\
\text { understanding, considering the peculiarities and specific interests of } \\
\text { different stakeholders }\end{array}$ & & & & & \\
\hline
\end{tabular}

SOC 1.3.1. If the answer was YES for alternative (c) to QUESTION 1.3, please indicate the stakeholders for whom this specific version is made available:

TI - Eradication of child labor

$\mathrm{TF}$ - Eradication of forced or compulsory labor

DI - Combating discrimination in all its forms

DV - Appreciation of diversity

AS - Prevention of bullying and sexual harassment

LA - Respect for free union association and the right to collective bargaining

\begin{tabular}{|l|l|l|l|l|l|}
\hline \multicolumn{1}{|c|}{ STAKEHOLDERS } & TI and TF & DI and DV & AS & LA & None \\
\hline a) Shareholders and Investors & & & & & \\
\hline b) Direct employees & & & & & \\
\hline c) Other members of the workforce & & & & & \\
\hline d) Suppliers & & & & & \\
\hline e) Consumers/Clients & & & & & \\
\hline f) Community & & & & & \\
\hline g) Government & & & & & \\
\hline h) Organized civil society & & & & & \\
\hline i) Other interested parties & & & & \\
\hline
\end{tabular}

Stakeholders' Relationships Based on Procedural Justice

ECO 16. In the past 5 years, the company, or its management when applicable:

a) It was convicted of a final decision/sentence in an administrative proceeding filed by the Federal Revenue Service

${ }^{1}$ Translated by the author. 
b) It was processed administratively for violations of the competition order, following Law $12.529 / 11$ or equivalent legislation abroad

c) It received from its independent auditors any safe conduct or adverse opinion or abstention in issuing an opinion due to work limitations (following Brazilian Accounting Standards), or equivalents abroad, in its financial statements

d) None of the above

ECO 17. Has the company, or its administrators when applicable, been convicted in Brazil and/or abroad, over the past 5 years, by a final decision/sentence in an administrative proceeding?

a) Yes, by the Central Bank of Brazil or equivalent institution abroad

b) Yes, by the Securities and Exchange Commission or equivalent institution abroad

c) Yes, by Agencies or Regulatory Entities

d) Yes, by Self-Regulatory Entities

e) There was no conviction

GOV 11. Check all the alternatives that apply concerning administrative, arbitration or judicial proceedings against the company, the managers or the controlling shareholder, involving nonequitable treatment of minority shareholders and/or breach of the managers' fiduciary duty, occurred in the last 5 years:

a) There was any unappealable conviction/decision

b) There was closure with the signing of a commitment term with the Securities and Exchange Commission of Brazil (CVM) in some process

c) There are processes in progress

d) There was irrecoverable acquittal in all processes

e) There has been no process in the last 5 years

SOC 5. Does the company have a corporate policy aimed at self-regulating the use of marketing instruments for its activities and products, incorporating ethical principles and respect for the consumer, the citizen, and the environment?

(GRI G4) Indicator PR7

(ISO 26000) Subsection 6.7.3 

a) Yes
b) No

SOC 5.1. If the answer was YES for QUESTION 5, does this policy guarantee respect for public spaces? Does it include mechanisms that avoid the transmission of misleading or abusive information or advertising communication and, in particular, that incites violence, exploits fear or superstition, takes advantage of the deficiency of judgment and experience of the child or other vulnerable groups, disrespects environmental values, or that can induce the public to behave in a way that is harmful or dangerous to their health or safety?
a) Yes
b) No

SOC 8. Does the company promote the engagement of its internal public, including direct employees and outsourced workers, in combating any practice of discrimination in terms of employment and occupation?

(GRI G4) Indicator HR3

(ISO 26000) Subsection 6.3.7
a) Yes
b) No

SOC 9. The commitment to appreciate diversity in terms of employment and occupation encompasses the activities of:

(Select one or more alternatives)

(GRI G4) Indicator HR3

(ISO 26000) Subsection 6.3.7
a) Selection and hiring
b) Promotion
c) Access to training
d) Awareness of direct employees and outsourced workers to the topic
e) None of the above 
SOC 18.1. The procedures adopted by the company to guarantee respect for privacy and the proper and consented use of the information collected about its customers/consumers or other parties with whom it relates in the course of its usual activities or its commercial efforts include: (Select one or more alternatives)

(GRI G4) Indicator PR8

(ISO 26000) Subsection 6.7.7

a) External audit regarding the effectiveness of established security systems to prevent access or misappropriation of information by third parties

b) Verification (internal or external) to avoid access or misuse of information by members of the company itself

c) Prior request to customers/consumers regarding using their data for any use other than those essential to the existing commercial relationship

d) Provision of simple and effective means for the consumer to request the interruption in the use of his data for commercial purposes, at any time, even if he has previously authorized them e) None of the above

SOC 18.3. Does the company promote the regular participation of consumer groups or entities that represent them, in the process of assessing the social impacts of its products and/or services?

(ISO 26000) Subsection 7.3.1

a) Yes, concerning new products and/or services

b) Yes, concerning strategic products and/or services

c) Yes, for all products and/or services

d) None of the above

SOC 18.4. Do the communication campaigns, which aim to promote education for the sustainability of consumers, count on the regular participation of entities representing consumers and/or specialized in this theme?

(GRI G4) Indicator PR6

(ISO 26000) Subsection 6.7.9
a) Yes
b) No

${ }^{1}$ Translated by the author. 
SOC 41.1. If the company has its products and services predominantly aimed at individuals, concerning legal or administrative proceedings arising from the company's relationship with customers/consumers of the products and services it offers:

(Select one or more alternatives)

(GRI G4) Indicator PR2

a) There are lawsuits pending by a supervisory entity, public agent or similar

b) There are administrative procedures in progress

c) There has been, in the last 3 years, some unappealable sentence/decision

d) There has been, in the last 3 years, some corrective measure resulting from a notice or warning by the regulator of the communication, advertising, and marketing activities

e) None of the above

SOC 41.3. If the company has its products and services predominantly aimed at other companies, concerning legal or administrative proceedings arising from the company's relationship with customers/consumers of the products and services it offers:

(Select one or more alternatives)

(GRI G4) Indicator PR2

a) There are lawsuits pending by a supervisory entity, public agent or similar

b) There are administrative procedures in progress

c) There has been, in the last 3 years, some unappealable sentence/decision

d) There has been, in the last 3 years, some corrective measure resulting from a notice or warning by the regulator of the communication, advertising, and marketing activities

e) None of the above

${ }^{1}$ Translated by the author. 